

\section{CONNECT WITH US}

wbg.org/Malaysia

f @WorldBankMalaysia

@WB_AsiaPacific

http://bit.ly/WB_blogsMY 


\section{MALAYSIA ECONOMIC MONITOR}




\section{(C) 2019 International Bank for Reconstruction and Development / The World Bank}

Sasana Kijang, 2 Jalan Dato Onn, Kuala Lumpur 50480, Malaysia

Some rights reserved.

This work is a product of the staff of The World Bank with external contributions. The findings, interpretations, and conclusions expressed in this work do not necessarily reflect the views of The World Bank, its Board of Executive Directors, or the governments they represent. The World Bank does not guarantee the accuracy of the data included in this work. The boundaries, colors, denominations, and other information shown on any map in this work do not imply any judgment on the part of The World Bank concerning the legal status of any territory or the endorsement or acceptance of such boundaries.

Nothing herein shall constitute or be considered to be a limitation upon or waiver of the privileges and immunities of The World Bank, all of which are specifically reserved.

\section{Rights and Permissions}

This work is available under the Creative Commons Attribution 3.0 IGO license (CC BY 3.0 IGO) http://creativecommons.org/licenses/by/3.0/igo. Under the Creative Commons Attribution license, you are free to copy, distribute, transmit, and adapt this work, including for commercial purposes, under the following conditions:

Attribution: Please cite the work as follows: World Bank (2019) "Making Ends Meet" Malaysia Economic Monitor (December), World Bank, Washington, DC.

Translations: If you create a translation of this work, please add the following disclaimer along with the attribution: This translation was not created by The World Bank and should not be considered an official World Bank translation. The World Bank shall not be liable for any content or error in this translation.

Adaptations: If you create an adaptation of this work, please add the following disclaimer along with the attribution: This is an adaptation of an original work by The World Bank. Views and opinions expressed in the adaptation are the sole responsibility of the author or authors of the adaptation and are not endorsed by The World Bank.

Third-party content: The World Bank does not necessarily own each component of the content contained within the work. The World Bank therefore does not warrant that the use of any thirdparty-owned individual component or part contained in the work will not infringe on the rights of those third parties. The risk of claims resulting from such infringement rests solely with you. If you wish to re-use a component of the work, it is your responsibility to determine whether permission is needed for that re-use and to obtain permission from the copyright owner. Examples of components can include, but are not limited to, tables, figures, or images.

All queries on rights and licenses should be addressed to World Bank Publications, The World Bank, 1818 H Street NW, Washington, DC 20433, USA; e-mail: pubrights@worldbank.org. 


\section{MALAYSIA ECONOMIC MONITOR DECEMBER 2019}

\section{Making Ends Meet}




\section{Acknowledgements}

This edition of the Malaysia Economic Monitor was prepared by Richard Record (Task Team Leader), Shakira Teh Sharifuddin, Yew Keat Chong, Mahama Samir Bandaogo, Kenneth Simler (Task Team Leader for Part 2), Dao Harrison and Zainab Ali Ahmad. Achim Schmillen, Samuel Fraiberger, Monica Biradavolu, Cristina Constantinescu, Amanina Abdur Rahman, Mei Ling Tan, Wei San Loh, Chancey Lee Pacheco, Franz Ruch, Sinem Celik, Linda Peng, Jorge Guzman, Steven Pennings, Norman Loayza, Young Kim, Sharmila Devadas, Vijayendra Rao, Niaz Asadullah, Urbanmetry, Rekha Reddy, Wei Zhang, Graciela Miralles, Joshua Foong and Clarissa David provided additional contributions.

Mara Warwick, Firas Raad, Ndiame Diop and Salman Zaidi provided overall guidance. The team is grateful to Hassan Zaman, Souleymane Coulibaly, Ekaterine Vashakmadze and Ergys Islamaj for their constructive input on the document.

This report benefited from productive discussions with staff from the Ministry of Economic Affairs, Bank Negara Malaysia, the Ministry of Finance, the Office of the Prime Minister, the Ministry of Domestic Trade and Consumer Affairs, the participants in a September 2019 workshop on the cost of living and many other government ministries and agencies, all of whom provided valuable information and useful feedback.

In particular, the team would like to thank the Strategic Planning and International Cooperation Division of the Ministry of Economic Affairs and the Economics Department of Bank Negara Malaysia for close ongoing collaboration with the World Bank and for the crucial support to the launch of this report. The team would also like to express its gratitude to analysts at several private financial firms and rating institutions, whose participation in a constructive dialogue also informed the analysis.

Joshua Foong and Min Hui Lee led external communications and the production and design of the report. Irfan Kortschak provided editing assistance, while Aziaton Ahmad provided administrative support. Kane Chong designed the report and its cover.

Photography: Samuel Goh

The report is based on information current as of December 2, 2019.

Please contact Richard Record (rrecord@worldbank.org), Yew Keat Chong (ychong@worldbank.org) or Shakira Teh Sharifuddin (stehsharifuddin@worldbank.org) if you have any questions, comments or suggestions regarding the Malaysia Economic Monitor. 


\section{Abbreviations}

\begin{tabular}{|c|c|}
\hline AKPK & $\begin{array}{l}\text { Credit Counselling and Debt Management Agency } \\
\text { (Agensi Kaunseling dan Pengurusan Kredit) }\end{array}$ \\
\hline AMI & Area Median Income \\
\hline ASEAN & Association of Southeast Asian Nations \\
\hline B40 & Bottom 40 percent (of the population) \\
\hline BNM & Bank Negara Malaysia \\
\hline BSH & Cost of Living Aid (Bantuan Sara Hidup Rakyat) \\
\hline CAGR & Compound Annual Growth Rate \\
\hline CPI & Consumer Price Index \\
\hline DE & Development Expenditure \\
\hline DFI & Development Finance Institution \\
\hline DMO & Debt Management Office \\
\hline DOSM & Department of Statistics Malaysia \\
\hline DSR & Debt Service Ratio \\
\hline E\&E & Electrical and Electronics \\
\hline EAP & East Asia and Pacific \\
\hline EIS & Employment Insurance System \\
\hline EMDE & Emerging Market and Developing Economies \\
\hline EPF & Employees Provident Fund \\
\hline EPI & Everyday Price Index \\
\hline FBM KLCl & FTSE Bursa Malaysia Index \\
\hline FDI & Foreign Direct Investment \\
\hline FEN & Financial Education Network \\
\hline FLFP & Female Labor Force Participation \\
\hline FMR & Fair Market Rent \\
\hline GDP & Gross Domestic Product \\
\hline GFCF & Gross Fixed Capital Formation \\
\hline GG & Government Guarantee \\
\hline GNI & Gross National Income \\
\hline GST & Goods and Services Tax \\
\hline GWP & Gallup World Poll \\
\hline HES & Household Expenditure Survey \\
\hline HIS & Household Income Survey \\
\hline HP & Hodrick-Prescott Filter \\
\hline ILO & International Labour Organization \\
\hline IMF & International Monetary Fund \\
\hline IPI & Industrial Production Index \\
\hline KPDNHEP & Ministry of Domestic Trade and Consumer Affairs \\
\hline KRI & Khazanah Research Institute \\
\hline LCR & Liquidity Coverage Ratio \\
\hline LFS & Labor Force Survey \\
\hline
\end{tabular}

\begin{tabular}{|c|c|}
\hline LTGM & Long Term Growth Model \\
\hline M40 & Middle 40 percent (of the population) \\
\hline MEM & Malaysia Economic Monitor \\
\hline MGS & Malaysian Government Securities \\
\hline MIER & Malaysian Institute of Economic Research \\
\hline MOF & Ministry of Finance Malaysia \\
\hline MTFF & Medium-Term Fiscal Framework \\
\hline MTR & Mid Term Review \\
\hline MVF & Multi-Variate Filter Model \\
\hline MyCC & Malaysia Competition Commission \\
\hline NACCOL & National Cost of Living Action Council \\
\hline NAPIC & National Property Information Center \\
\hline NSLF & National Strategy for Financial Literacy \\
\hline OE & Operating Expenditure \\
\hline OECD & $\begin{array}{l}\text { Organization for Economic Cooperation and } \\
\text { Development }\end{array}$ \\
\hline OPR & Overnight Policy Rate \\
\hline PePI & Perceived Price Index \\
\hline PFI & Private Finance Initiative \\
\hline PIR & Price Income Ratio \\
\hline PLI & Poverty Line Income \\
\hline PPAM & $\begin{array}{l}\text { Public Service Housing Scheme (Perumahan Penjawat } \\
\text { Awam Malaysia) }\end{array}$ \\
\hline PPP & Public Private Partnership \\
\hline PPR & Public Low-Cost Housing (Projek Perumahan Rakyat) \\
\hline PR1MA & $\begin{array}{l}\text { 1Malaysia People's Housing Program (Perumahan } \\
\text { Rakyat 1Malaysia) }\end{array}$ \\
\hline PSP & Petrol Subsidy Program \\
\hline RPGT & Real Property Gains Tax \\
\hline RUMAWIP & $\begin{array}{l}\text { Federal Territories Affordable Homes Program } \\
\text { (Rumah Mampu Milik Wilayah Persekutuan) }\end{array}$ \\
\hline socso & Social Security Organization \\
\hline SPI & Spatial Price Index \\
\hline SRR & Statutory Reserve Requirement \\
\hline SST & Sales and Services Tax \\
\hline SVDP & Special Voluntary Disclosure Program \\
\hline SWRC & $\begin{array}{l}\text { Social Wellbeing Research Centre, University of } \\
\text { Malaya }\end{array}$ \\
\hline T20 & Top 20 percent (of the population) \\
\hline TFP & Total Factor Productivity \\
\hline TRC & Tax Reform Committee \\
\hline UC & Unobserved Components Model \\
\hline $\mathrm{Y} / \mathrm{Y}$ & Year-on-Year \\
\hline
\end{tabular}




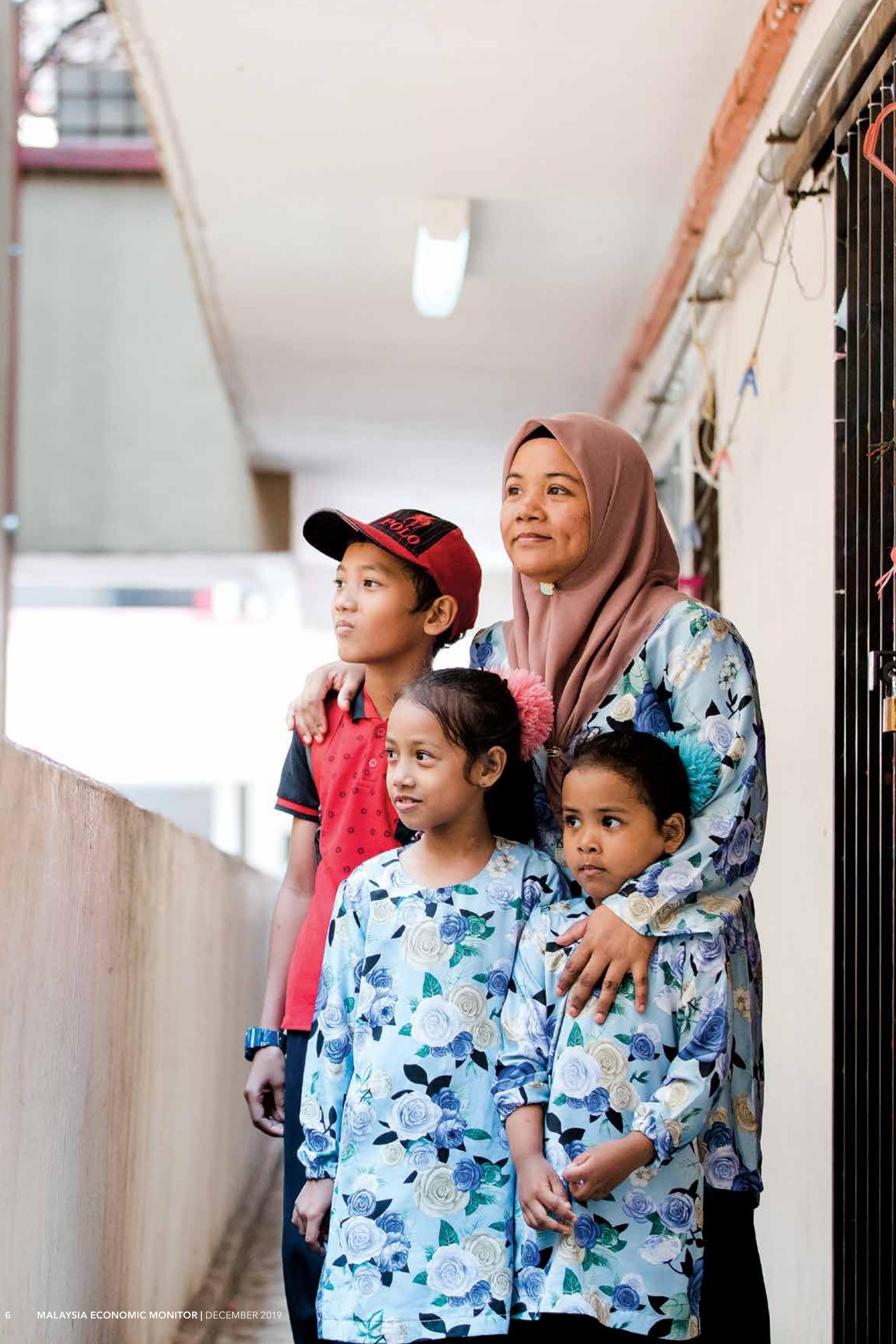




\section{Table of Contents}

Acknowledgements
Abbreviations
Summary
$\quad$ Recent economic developments
$\quad$ Economic outlook
$\quad$ Making ends meet

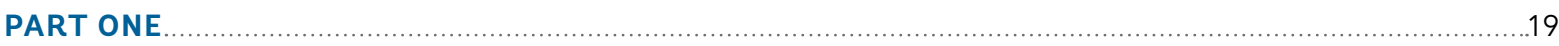

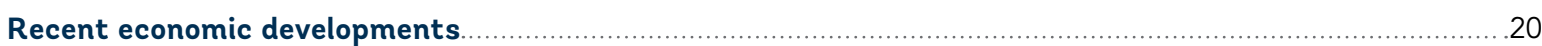

Regional growth has slowed amid challenging external conditions ...........................................................2

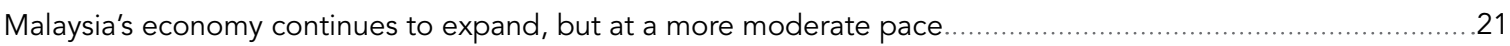

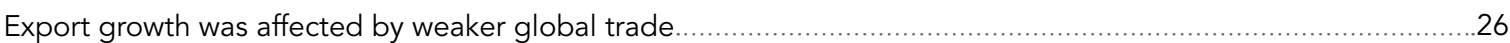

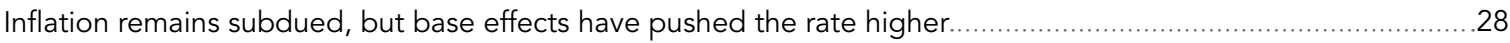

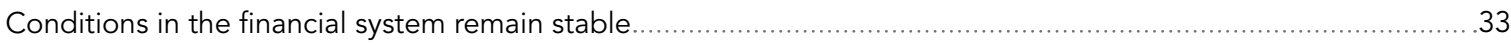

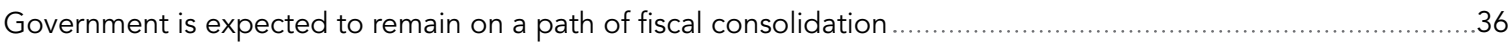

Fiscal policy in 2020 balances the need to preserve fiscal sustainability and support economic growth .................39

Economic outlook

Growth in developing EAP is projected to decelerate over the forecast horizon .............................................44

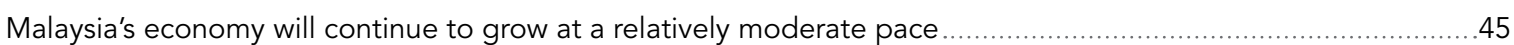

Risks to growth outlook are firmly on the downside amid challenging external conditions ...............................47

Near-term policies should focus on boosting resilience and protecting the vulnerable .....................................48

PART TWO

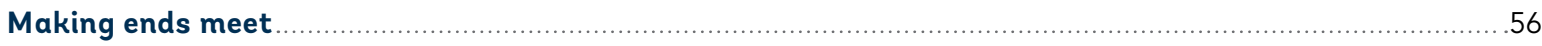

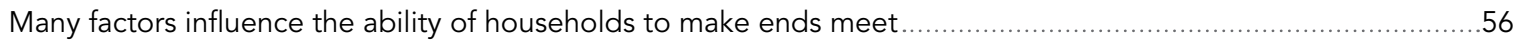

Overall, price increases for most goods and services have been low and stable ........................................56

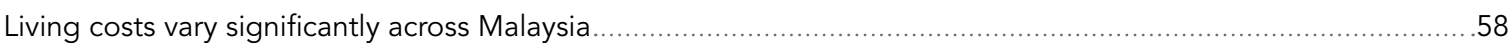

Many Malaysians, especially in urban areas, feel their income is insufficient to raise their living standards ............61

Lower-income households' income growth has slowed considerably in recent years .........................................66

Despite rising educational attainment, income growth among younger workers has been sluggish.......................66

Borrowing provides temporary income support to lower-income households ............................................... 71

Beyond housing and car loans, lower-income borrowers tend to use personal finance loans and credit

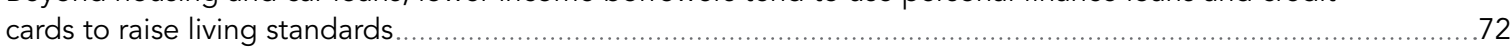

Malaysian households, particularly lower-income households, do not have adequate financial savings .................78

The availability of affordable housing in Malaysia has deteriorated over the years ..........................................80

Access to affordable housing varies significantly by location and household circumstances ..............................82 82

Government housing policies have diverse impacts on housing supply and affordability ...............................86

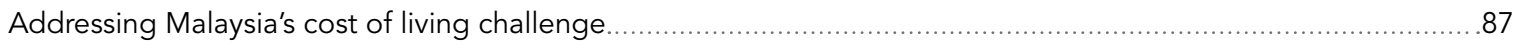

Alleviating cost of living pressures demands a mix of short-term measures as well as medium- and

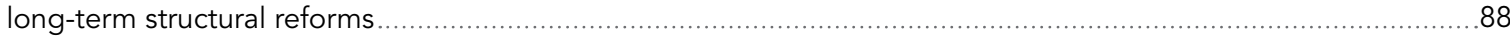

Short-term measures need to focus on alleviating hardships among lower-income households ...........................89

Over the long run, greater coordination across agencies and implementation of structural reforms could

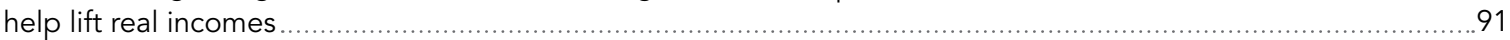

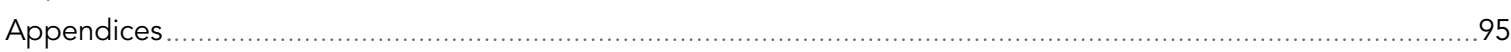




\section{Summary}

\section{Malaysia's economy is continuing to see growth, but the pace of expansion has moderated}

Growth slowed to 4.4 percent in Q3 2019, as subdued global conditions and heightened uncertainty continued to weigh on the economy. Investment and trade activity was softer than expected during the quarter, and indicators suggest overall business sentiment remains muted.

In 2020, Malaysia's economy is projected to expand at a relatively moderate pace, amid continued uncertainty and external headwinds. The GDP growth rate is projected to reach 4.5 percent in 2020 . Investment is expected to improve but remain subdued over the near term, with both the public and private sectors adopting a cautious stance towards capital spending. Similarly, the softness in export growth is likely to persist into next year, mirroring the continuing subdued global growth.

Short-term policies should focus on measures to boost resilience and protect the vulnerable. Federal debt has increased, and government revenue as a share of GDP is expected to decline further next year. In the context of a more uncertain economic environment, it is vital for Malaysia to preserve fiscal space to enable it to mitigate the impact of any negative shocks to the economy. Increased progressivity in the personal income tax framework and an expansion of current tax measures could enable the government to both increase revenues and improve redistribution.

Malaysia's weakening trade and investment activity, amid challenging external conditions, underscores the need to improve private sector confidence and strengthen investment competitiveness. With sluggish global demand and increased protectionist tendencies among the major economies, a sustained commitment to deepening regional integration and addressing trade barriers is vital to preserve a vibrant trading environment and build investors' confidence. It is also important to strengthen Malaysia's competitiveness in attracting quality investments and to maximize the gains from tax expenditures with better targeting of investments towards economic upgrading, high-value job creation and inclusive growth.

In the medium-term, structural reforms should focus on measures to address critical gaps in human capital formation, to facilitate economic opportunities for women, and to enhance opportunities for the private sector. To facilitate enhanced human capital development, deeper reforms are required to improve the quality of learning through the provision of better pre-school services and improved in-school assessments, and to reduce childhood stunting with multi-pronged solutions. Facilitating equal access to economic opportunities for women would also yield significant gains in the long term. Policies to raise the incomes and economic security of lower-income segments of the population could be sharpened to ensure continuous improvement of well-being for all Malaysians.

The Malaysia Economic Monitor (MEM) consists of two parts. Part 1 presents a review of recent economic developments and a macroeconomic outlook. Part 2 focuses on a selected special topic that is key to Malaysia's medium-term development prospects and 
the achievement of shared prosperity. In this edition, the focus of the special topic is on the cost of living, or making ends meet.

At present, there is a large gap between key macroeconomic indicators related to growth, income and inflation, and citizens' perceptions regarding the cost of living. Despite consistently low rates of inflation, concerns are frequently raised regarding this issue, which featured prominently as a campaign issue during the 2018 election campaign. A number of recent policy measures, including the abolition of the Goods and Services Tax and its replacement with the Sales and Services Tax and the reinstatement of fuel price subsidies, have been implemented in direct response to citizens' concerns regarding the cost of living. Sustainably addressing these concerns will require a mixture of short-term measures to alleviate hardships among lower-income households, as well as medium- to long-term structural reforms to help lift real incomes.

\section{Recent economic developments}

While Malaysia's economy is continuing to expand, the growth rate has decelerated to 4.4 percent in Q3 2019 (Q2 2019: 4.9 percent). Private consumption remained the largest contributor to output growth, expanding at a slower, but still robust rate of 7.0 percent in Q3 2019 (Q2 2019: 7.8 percent). Household spending was supported by moderate inflation and continued private sector employment and wage growth.

Gross fixed capital formation contracted for the third consecutive quarter, owing to weakerthan-expected business investment growth and continued contraction in public investment. Private investment growth slowed to 0.3 percent in Q3 2019 (Q2 2019: 1.8 percent), largely due to subdued trade activity and muted business sentiment. Public investment contracted for the eighth consecutive quarter to 14.1 percent in Q3 2019 (Q2 2019: -9.0 percent).

On the supply side, growth in key sectors (services, manufacturing and agriculture) moderated, with contractions in the mining and construction sectors. Services grew at the rate of 5.9 percent in Q3 2019, down from 6.1 percent in Q2 2019. After a moderate rebound in Q2 2019, manufacturing output growth decelerated to 3.6 percent in Q3 2019. The rebound in mining and quarrying was not sustained. Output shrank by 4.3 percent in Q3 2019, compared to growth of 2.9 percent in Q2 2019.

With weak global demand, the decline in export demand deepened. Against the backdrop of subdued global growth and ongoing trade tensions, exports of goods and services shrank by 1.4 percent in Q3 2019 (Q2 2019: 0.1 percent). Exports of manufactured goods declined, led by a considerable fall in electric and electronic exports. While there is evidence that Malaysia has gained market share in China and the US among tariff-affected products, these gains have been offset by weakening demand for exports in aggregate. Further, commodities exports declined due to a large contraction in petroleum exports, as some oil fields were temporarily closed for maintenance.

Imports of goods and services recorded negative growth for the third consecutive quarter. The decline in goods and services imports deepened in Q3 2019 to -3.3 percent (Q2 2019: -2.1 percent). Consistent with the decline in gross capital formation, imports of capital goods dropped by 15.4 percent in Q3 2019, led by a fall in machinery and transport equipment imports. The current account surplus narrowed to 3 percent of GDP in Q3 2019 (Q2 2019: 3.8 percent) due to a larger income deficit.

\section{It is important to strengthen Malaysia's competitiveness in attracting quality investments.}

In Q3 2019, the headline inflation rate increased to 1.3 percent (Q2 2019: 0.7 percent), reflecting the dissipating impact of the GST zeroization last year. During the period, the contribution of transport costs to headline inflation was negative owing to the decline in the RON97 petrol price amid lower average global oil prices. In Q3 2019, the core inflation rate remained stable at 1.5 percent (Q2 2019: 1.6 percent).

Financial soundness indicators show that the banking system remains resilient. Financial institutions continue to record sound levels of profitability, and the gross impairment ratio has remained stable. The overall level of household debt increased slightly to 82.4 percent of GDP as of endSeptember 2019 (end-June 2019: 82.2 percent). 
The recent performance of the domestic financial markets has been mixed. Non-resident inflows have contributed to the decline of Malaysian Government Securities yields. The ringgit broadly weakened against the US dollar, in line with most regional currencies.

The government is expected to meet its fiscal deficit target of 3.4 percent of GDP in 2019. Federal government revenue is expected to reach 17.4 percent of GDP, slightly higher than the initial estimate of 17.1 percent, mainly attributed to an increase in estimated SST collections. The higher revenue collection is, however, offset by higher operating expenditures which are estimated to expand to 17.3 percent of GDP, exceeding its initial estimate of 17.0 percent of GDP. This is partly due to higher spending on fuel subsidies following the delay in the implementation of the targeted fuel subsidy program. Meanwhile, development expenditure is projected to decline marginally from the initial estimate of 3.6 percent of GDP to 3.5 percent following the revision and re-timing of several infrastructure projects.

\section{Increased progressivity in the tax framework could enable the government to both increase revenues and improve redistribution.}

Federal government debt in proportion to GDP increased to 52.7 percent in Q2 2019 (2018: 51.2 percent), with risks remaining manageable. Exposure to currency risk is limited, with ringgitdenominated securities constituting of 96.3 percent of federal government debt (2018: 97.1 percent). Rollover risk is also limited with the debt structure skewed towards longer-tenured issuances. Domestic institutional investors remain the largest holders of government debt, accounting for 66.8 percent of total outstanding debt (2018: 66.7 percent) with nonresident holdings relatively stable at 22.1 percent (2018: 22.7 percent). Debt service charges are expected to reach 14.1 percent of federal government revenue in 2019 (2018: 13.1 percent).

Federal government debt and liabilities was also higher at 77.1 percent of GDP in Q2 2019 (2018: 75.4 percent). The slight increase compared to 2018 was mainly due to an increase in committed guarantees, with their value increasing from 9.2 percent of GDP in 2018 to 10.4 percent as of Q2 2019.
Malaysia's Budget 2020 represents a prudent balance between the competing needs of preserving fiscal sustainability while also effectively responding to challenging external conditions. The government's fiscal consolidation will continue in 2020, albeit with a revised fiscal deficit target of 3.2 percent of GDP, from the original target of 3.0 percent. Total government expenditure is expected to remain at 18.4 percent of GDP in 2020. The civil service wage bill, which is expected to account for 36.9 percent of total government expenditure (2019e: 38.9 percent), continues to dominate OE.

Federal government revenue is expected to decline further in 2020 to 15.2 percent of GDP (2019e: 15.4 percent). Tax revenue is expected to remain stable at 11.8 percent of GDP. Of this tax revenue, the largest proportion will be derived from direct tax (75.1 percent of total tax revenue). Corporate and personal income tax are expected to remain relatively stable, at 4.7 percent and 2.3 percent of GDP respectively. Indirect tax collection is also expected to remain constant, at 2.9 percent of GDP. Proceeds from the SST, which contribute the largest share of indirect tax, are expected to stand at 1.8 percent of GDP (2019e: 1.8 percent. Petroleum-related revenue as a share of federal government revenue is expected to decline to 20.7 percent in 2020 (2019e: 21.7 percent) due to projected lower crude oil prices.

In Budget 2020, the government has announced a number of measures to diversify its revenue base and to achieve greater progressivity in its tax framework. This includes a proposal for a new income tax band for taxable income in excess of RM2 million, to be taxed at 30 per cent, which is a 2-percentage point increase from the current rate of 28 per cent. The proposed increase would affect approximately 2,000 top income earners in the country. In addition, the government also announced the extension of SST to cover imported digital services, to take effect in January 2020 


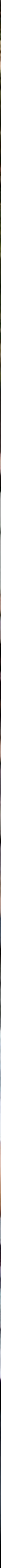




\section{Economic outlook}

Malaysia's economic activity is projected to grow at a relatively moderate pace in 2020 amid increased headwinds. The forecast for Malaysia's GDP growth in 2020 is revised down slightly to 4.5 percent (2019f: 4.6 percent), largely due to weaker-thananticipated investment and export growth in Q3 2019. Private consumption is projected to expand at a still robust rate of 6.5 percent next year (2019f: 7.1 percent), underpinned by stable labor market conditions, relatively benign inflation, and continued support from government measures. In the public sector, the planned rationalization of government operating expenditure will continue to weigh on the contribution from government consumption, which is projected to grow at 1.8 percent in 2020 (2019f: 1.7 percent).

Gross fixed capital formation is expected to improve but remain subdued over the near term, with both the public and private sectors continuing to adopt a cautious stance regarding capital spending. Overall investment activity is projected to expand at 1.4 percent next year (2019f: -1.8 percent), 0.3 percentage points lower than in the previous forecast. The downward revision largely reflects weaker-than-expected private investment activity in Q3 2019, as subdued trade prospects and increased uncertainty weighed markedly on business confidence and investment intentions. Public investment is likely to continue its contraction over the near term, albeit at a lesser extent following increased planned investments by public corporations in the transport and mining sectors. Inventory destocking begun in Q1 2018 is expected to normalize and provide modest support to growth over the forecast period.

Export growth is likely to remain soft into next year, reflecting subdued global investment and trade activity. Malaysia's export growth is projected to remain modest at 0.5 percent next year (2019f: -0.2 percent) in the context of challenging global economic conditions and prolonged trade-related uncertainty. This is expected to be partially offset by a recovery in mining exports from unforeseen supply disruptions in recent quarters. Similarly, import growth is projected to pick up modestly at 0.4 percent in 2020 (2019f: -1.8 percent), as growth of intermediate and capital exports regains some momentum with slight improvements in export and investment activity. The current account surplus is projected to narrow to around 3.0 percent of GDP in 2020, with a more moderate trade surplus in goods continuing to offset the persistent deficits in services and income accounts.
Headline inflation is projected to increase modestly in 2020 as the effects of policyrelated factors dissipate. Consumer price inflation is projected to average higher in the range of 1.5-2.0 percent next year (2019f: 0.7 percent), mainly reflecting the lapse in the effects of consumption tax policy changes in 2018. Additionally, the reintroduction of the float pricing mechanism for RON95 petrol and diesel in January 2020 is expected to result in modest increases in transportation costs at the prevailing global oil prices.

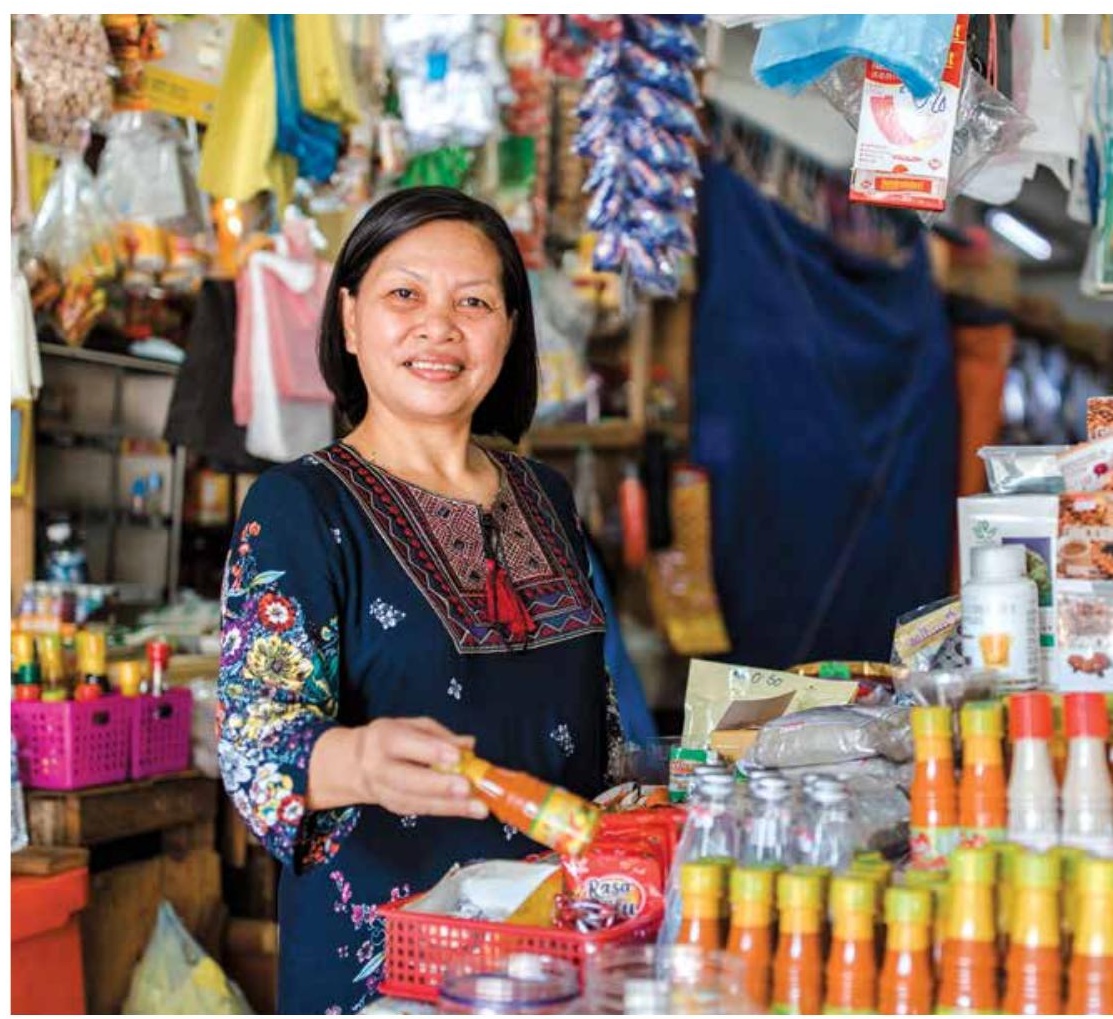

Various downside risks in the global economy could have spillover effects on Malaysia's economy. Further escalation of the current trade tensions between the US and China could further contribute to growing uncertainty and dampen investment activity. Moreover, deepening of the slowdown in the major economies, as well as a sharper-than-expected deceleration in China could lead to deterioration in export and growth prospects. Further, an unexpected drop in commodity prices could affect growth and lead to further fiscal pressures in Malaysia.

On the domestic economic front, risks to growth primarily emanate from factors related to prolonged uncertainty among investors and delayed recovery in commodity-related sectors. Investment growth has been subdued over the recent 
quarters, weighed down by lower capital spending. Indicators of business sentiment suggest the level of confidence in the economy remains low. While uncertainty regarding the global economic outlook would have an impact on Malaysia's economy, similar uncertainty regarding the domestic economy and political developments could exacerbate cautious sentiment, further dampening private investment.

Elevated government debt and liabilities, the continuing decline in government revenue, coupled with increased locked-in expenditures, will constrain fiscal policy space. Given the more uncertain economic environment, preserving fiscal space is important to mitigate the impact of any negative shock to the economy. General government revenue in proportion of GDP is expected to decline further to 17.9 percent in 2020, which is well below its regional and aspirational comparators, and Malaysia significantly under-collects in key revenue areas including personal income and consumption taxes. Moreover, increased locked-in expenditures such as the wage bill and debt servicing costs have put a limit on development and social spending, capping the effectiveness of fiscal policy as a redistributive tool for shared prosperity.

Increased progressivity in the personal income tax framework and an expansion of current tax measures could enable the government to increase revenues and to improve redistribution. The government has taken a step in the right direction when it proposed a new top income tax band in Budget 2020. Nonetheless, more could be done on this end, including raising the tax bracket for the other higher income bands, and reviewing the tax reliefs and exemptions applied. In addition, the scope of the real property gains tax could be widened by extending the scope of the tax, particularly for owners of multiple properties, and increasing stamp duty on purchases of higher-value properties. These measures could result in significant increases to revenue while having minimal impact on lower- and middle-income households. Finally, a gradual lifting of the exemptions on selected non-essential items, particularly those not within the B40 consumption basket, could also facilitate increased revenue without jeopardizing the purchasing power of lower-income households.

A more challenging external environment underscores the need to increase trade diversification and strengthen investment competitiveness. In an environment of subdued global demand and increased protectionist tendencies among the major economies, a sustained commitment to deepening regional integration and addressing trade barriers is pivotal to preserve a vibrant trading environment and send confidence-building signals to investors. It is also important to strengthen Malaysia's competitiveness in attracting quality investments and to improve targeting and the return on tax expenditures so as to maximize the gains from investments towards economic upgrading, high-value job creation and inclusive growth.

\section{Facilitating equal access to economic opportunities for women would also yield significant gains in the long term.}

Medium-term structural reforms should focus on addressing critical gaps in human capital, facilitating economic opportunities for women and improving private sector opportunities to ensure sustainable and inclusive growth. Making greater gains in human capital development will require deeper reforms to improve the quality of learning through better pre-school services and improved inschool assessments, and to reduce childhood stunting with multi-pronged solutions. Facilitating equal access to economic opportunities for women would also yield significant gains in the long term. Concurrently, policymakers should also sustain reform efforts to promote healthy competition, strengthen public procurement and address distortions in labor and output markets to improve private sector participation in the economy. 


\section{Making ends meet}

Despite Malaysia's low and stable inflation rate, there has been an ongoing debate regarding perceived increases to the cost of living in the country. These concerns are frequently expressed in public policy debates, in the mass media, and in private conversations. The issue has featured prominently in public and private discourse for years, dating back at least to the introduction of the GST in April 2015 and the rationalization of the fuel subsidy in December 2014. And more recently there has been a robust public debate about whether Malaysia should increase its nationally-defined poverty line. It is particularly noteworthy that these concerns have emerged during a period of low inflation, with the headline inflation rate averaging around 2 percent since 2015 (except in 2017 when it was 3.8 percent), well below the growth rates for the economy and average nominal income.

In this context, the "cost of living" is frequently used as a catch-all term that may reflect wider developments in the economy and their impacts on household budgets and well-being. While the discussion is usually framed as an issue of rising costs of goods and services, for most Malaysians the core issues extend beyond prices. These include lagging income growth and increasing housing costs, resulting in lower discretionary income. In addition, high indebtedness and inadequate financial savings also feed into the concerns of housing affordability and the cost of living for many Malaysians.

Overall, price increases for most goods and services have been low and stable. The consumer price index shows that Malaysia's inflation rate has been moderate in recent years. This is especially true for core inflation, which excludes items with more volatile prices (especially energy and food commodities); items with administered prices; and the estimated direct impacts of changes in consumption tax policy. The year-on-year core inflation rate has consistently been less than 2.6 percent since mid-2016.

Living costs vary significantly across Malaysia. While the evolution of prices over time in Malaysia is well measured and documented, comparatively little attention is given to the large differences in price levels across places. Moving around the country it is readily apparent that some places are more expensive in general than others. The most obvious spatial price differences are in housing, where location is an inherently critical component of property values, but there is also significant spatial price variation across a wide range of common goods and services.

Because of spatial price differences, the purchasing power of a ringgit varies from place to place, which directly impacts the cost of living. It is no secret that Johor, Kuala Lumpur and Selangor are Malaysia's high-cost environments, and that costs tend to be lower in states such as Kedah, Kelantan and Perlis. If household incomes varied across these areas in exactly the same proportion as costs then that would neutralize the effect of spatial price differences on the cost of living. However, incomes do not vary in the same way, especially if one looks beyond the averages.

Increasing numbers of Malaysians, especially in urban areas, feel their income is insufficient to meet the cost of living. Real household incomes have been consistently increasing over the past two decades, sometimes quite rapidly, yet for many the gains have not kept up with their expectations. In particular, from 2009 to 2014 income growth rates for the B40 were substantially higher than for the M40 and T20, but more recently (2014-2016) income growth slowed for the B40, trailing that of the M40. Feelings of being "left behind" are likely compounded by the fact that absolute income gaps have consistently increased over time.

Despite rising educational attainment, income growth among younger and less educated workers has been sluggish. While incomes for all age groups have tended to grow at a faster rate than inflation, the growth in employment earnings in the case of younger workers has consistently lagged those of their older counterparts. Employment earnings for those who have only completed secondary education are not only substantially lower than those with higher education, but their real wage growth over time has also been persistently low.

Those who feel their incomes are not keeping up with the cost of living often opt to work more to try to make ends meet. This could mean a nonworking household member deciding to start working or a working household member taking on a second or even third job. Qualitative research suggests that increases in the number of workers per household and the number of people holding multiple jobs is greater than that indicated by quantitative data.

Borrowing provides temporary income support to lower-income households. Borrowing provides temporary relief for households to compensate for inadequate income, particularly in the short-term. While debt provides opportunities for shifting consumption 


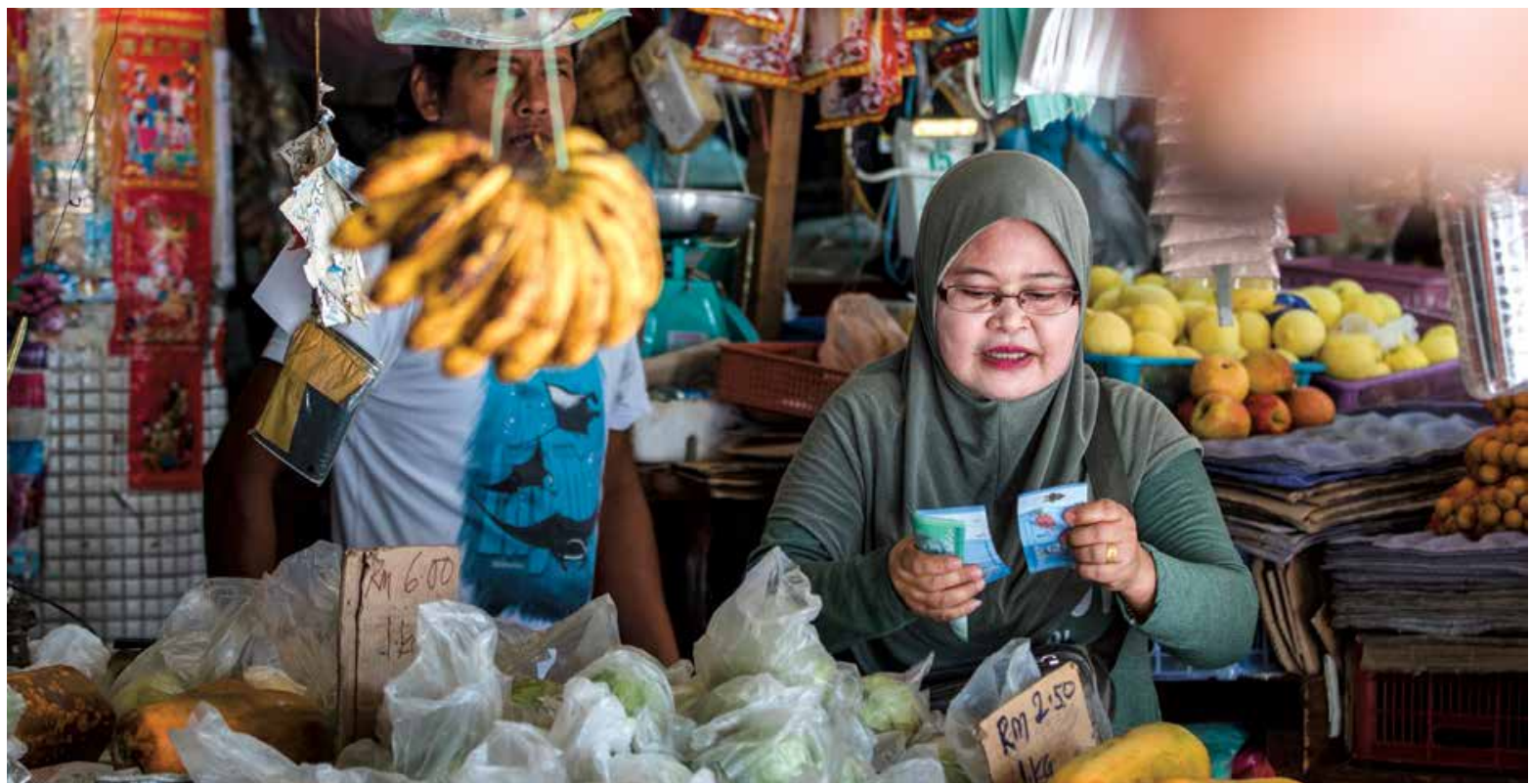

and making investments, over the long run, it also limits available discretionary income for households in Malaysia. Lower-income households and population sub-groups have a heavy debt load and face high debt service ratios. More than 40 percent of borrowers with monthly household incomes less than RM3,000 spend more than 40 percent of their income on debt repayment. Among lower-income borrowers, debt is mostly for motor vehicles and personal financing, thus supporting consumption as opposed to longer-term investments to build wealth.

Housing affordability in Malaysia has deteriorated over the years. Housing is a basic need, with the cost of meeting this need usually constituting one of the largest items of household expenditure. Various studies using the price-income ratio (PIR) have shown that the affordability of housing in Malaysia has deteriorated, such that housing is now "severely unaffordable" in several states and "seriously unaffordable" in Malaysia as a whole according to that measure. For this report, the World Bank has developed a new housing affordability model that is more detailed than the PIR and better equipped for the analysis of housing affordability across the distributions of incomes and house prices. When applied to detailed housing and income data for Kuala Lumpur and Petaling District (as case studies) it is possible to analyze the income levels and housing price points where housing unaffordability is most critical.

The lack of affordable housing is particularly severe among households earning less than RM5,000. It is estimated that the number of households in this income group far exceeds the supply of housing affordable to them, with 55 percent in Kuala Lumpur and 63 percent in Petaling District lacking access to housing that they can afford. Households in the RM6,000 to RM10,000 income bracket can typically afford to purchase a home in the RM230,000 to RM500,000 price range, but the availability of such homes is very uneven. The market for such homes that are affordable for this income group is much tighter in Petaling District than in Kuala Lumpur, given Petaling's growing under-supply and increase in prices.

Alleviating cost of living pressures demands a mix of short-term measures as well as mediumand long-term structural reforms. Until recently, many of the measures targeted at addressing the cost of living have been relatively ad hoc, fragmented and short-term in nature. Some of the policies that the government has implemented include subsidies, administrative price controls, construction of affordable housing, concessional mortgage financing, and credit counseling. As factors affecting households' living standards are wide-ranging and tend to overlap to some degree, a more structured approach to address higher living costs and improving well-being among Malaysians can be organized into short-term measures as well as medium- and long-term structural reforms. Short-term measures need to focus on alleviating hardships among lower-income households through deepening of social safety nets, while over the long run, increased coordination across agencies and implementation of structural reforms to foster greater market competition and accelerate productivity could help lift real incomes for all. 


\section{Recent trends in Malaysia's economy}

Malaysia's economic activity has moderated...

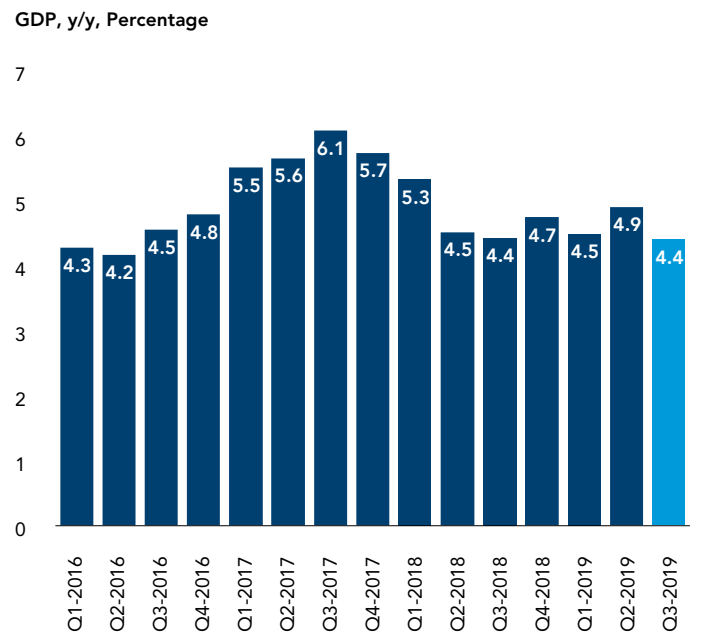

Exports have seen negative growth amid weak external demand...

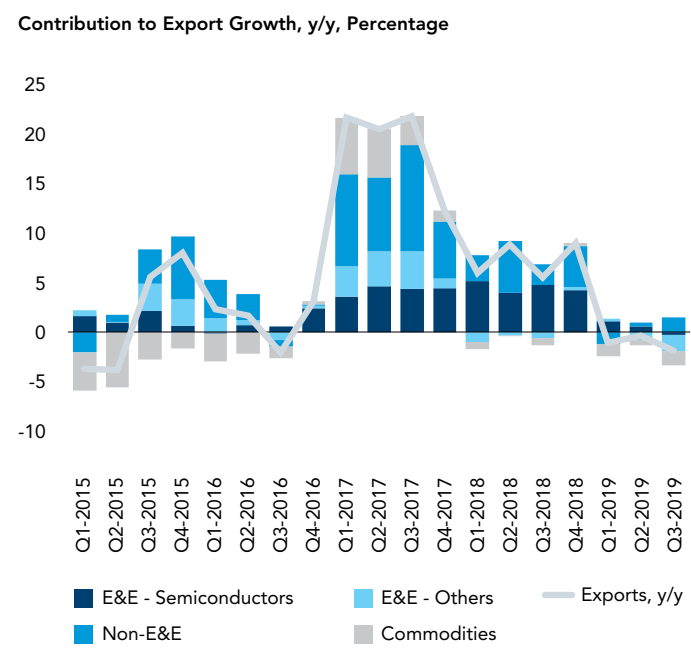

Malaysia's economy is forecast to expand at 4.5 percent in 2020 ...

GDP, $y / y$, Percentage

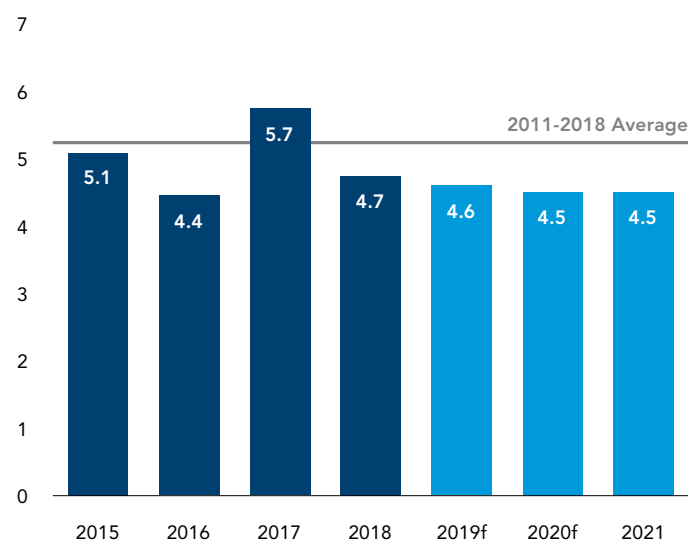

...weighed down by negative investment growth

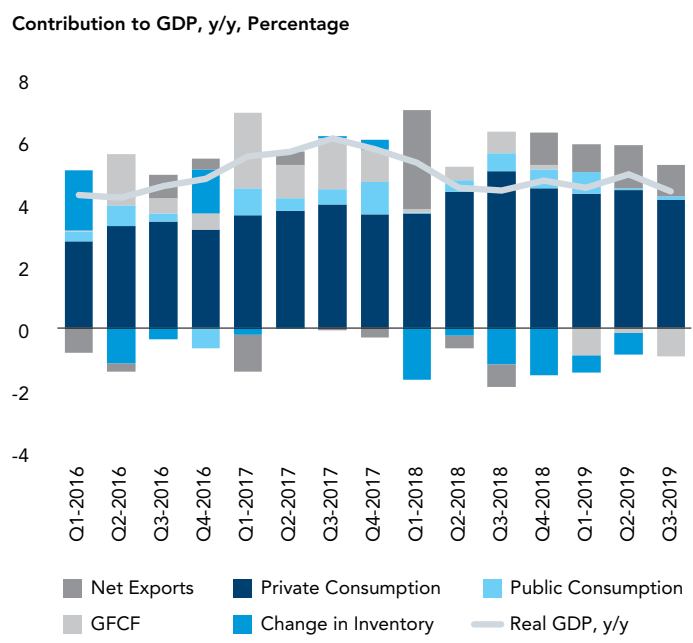

....and the performance of the domestic financial markets has been mixed

Non-resident Portfolio Flows, RM Billion

15

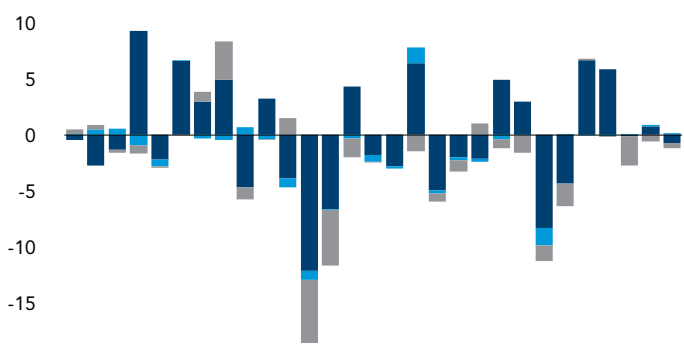

$-20$

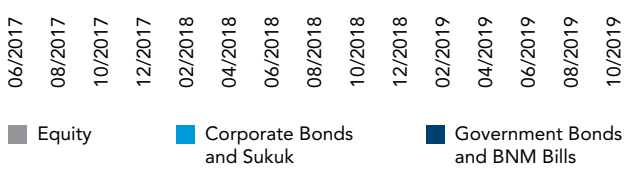

...with private consumption remaining the main driver of growth

Contribution to GDP, $y / y$, Percentage

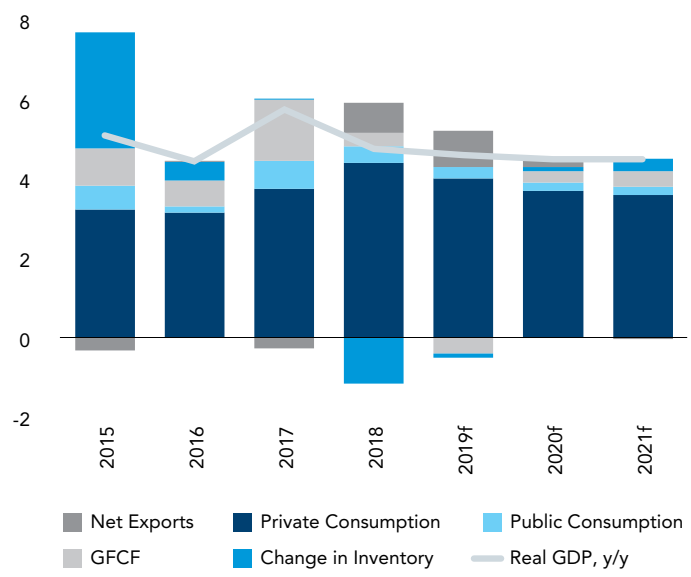




\section{Making ends meet}

Higher incomes in some urban areas are partly offset by higher prices, with the opposite in most rural areas

Median Gain/Loss in Purchasing Power in 2016, RM per Month

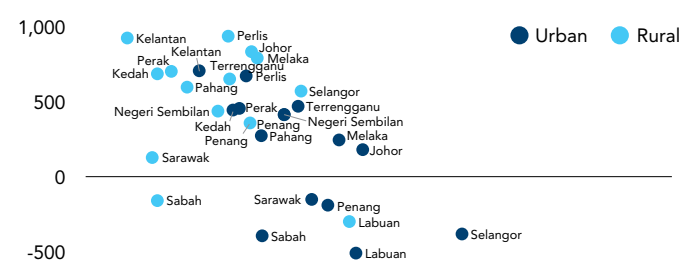

$-1,000$

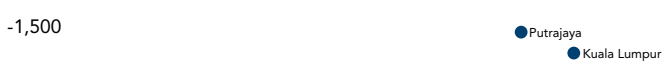

$-2,000$

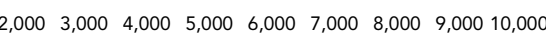

Median Gross Household Monthly Income

Lower-income borrowers have high debt service ratios, leaving little room for savings or discretionary expenditures

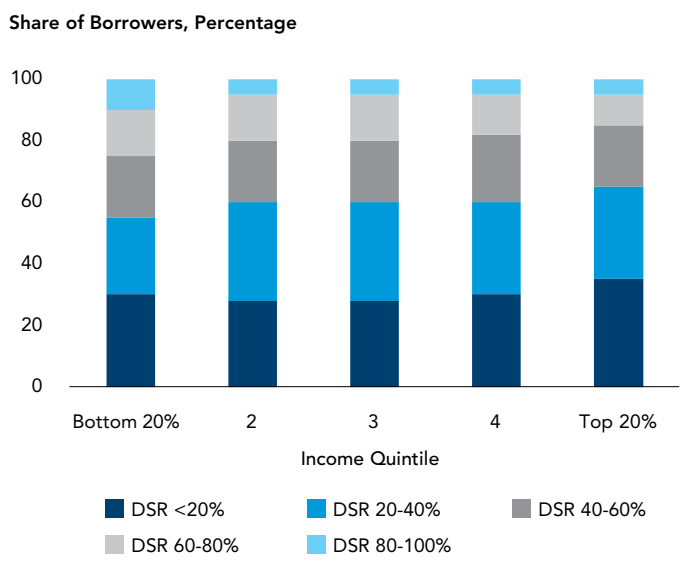

Lower-income households cannot afford to spend as large a percentage of their income on housing

Maximum Affordable Home Value, RM

....itithl|

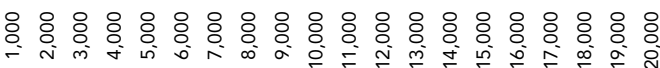

Monthly Income (RM)
Since 2004, real growth in employment income for 20-29 year-olds with postsecondary education has been marginal

Median Monthly Employment Income with Post-Secondary Education, Constant RM

7,000

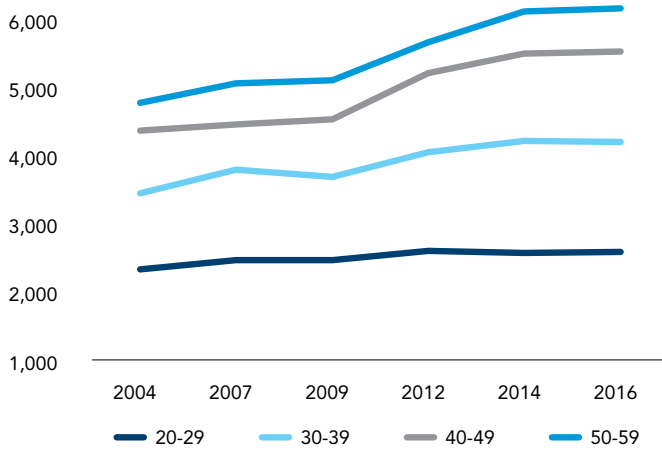

About half of Malaysian working adults lack financial resilience, especially the younger generation

Number of Individuals by Age Group, Percentage

100

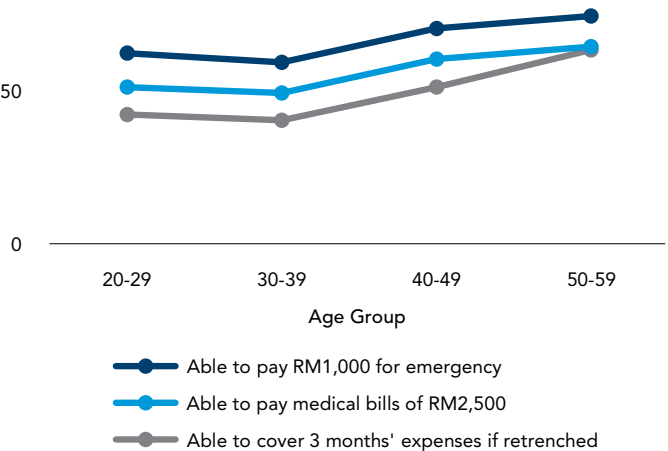

There is an under-supply of housing units that cater for lower-income households in Kuala Lumpur

Cumulative Number of Housing Units and Households, Thousands

700

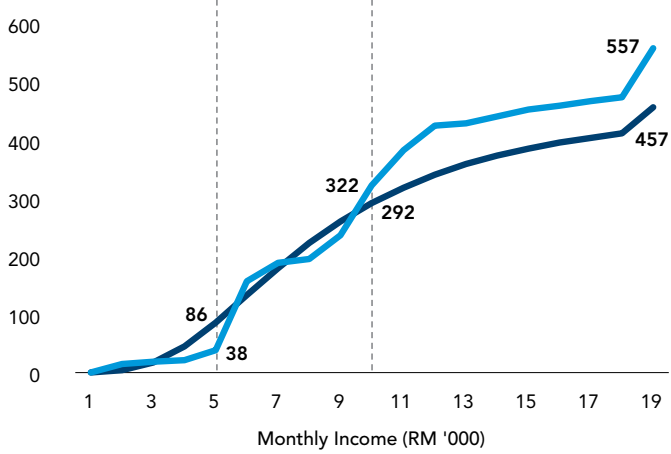

- Cumulative Number of Households

- Cumulative Housing Units 


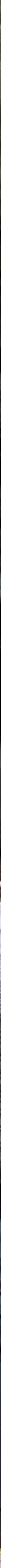




\section{PART ONE}

\section{Recent Economic Developments and Outlook}




\section{Recent economic developments}

\section{Regional growth has slowed amid challenging external conditions}

Global growth has remained subdued, with trade and manufacturing activity showing continued signs of weakness. The global growth rate is estimated to have slowed to 2.4 percent $^{1}$ in Q2 and Q3 2019 (Q1 2019: 2.5 percent), with weaker growth observed in several major economies, including United States, China and Japan (see Figure 1). Global investment and trade activities have remained subdued in the context of weak global demand and continued trade policy uncertainty. In response to weakening activity and generally low inflation, central banks in advanced economies have loosened monetary policy, contributing to notable declines in global bond yields. Recent survey indicators suggest that the global economy remains weak but is showing incipient signs of stabilization.

\section{FIGURE 1}

Global growth has remained weak with subdued trade and investment activity

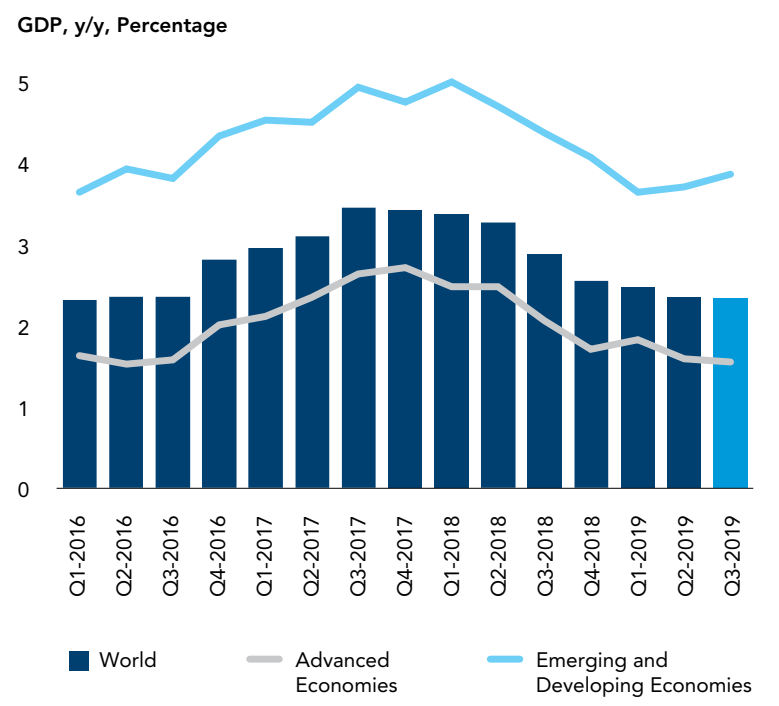

Growth also decelerated in the East Asia and Pacific (EAP) region, with the rate declining to 5.8 percent in Q3 2019 (Q2 2019: 5.9 percent) (see Figure 2). In China, the growth rate slowed to 6.0 percent during Q3 2019 (Q2 2019: 6.2 percent), mainly due to a moderation in manufacturing and industrial activity amid trade policy uncertainty. Growth in the region's other economies has also moderated in recent quarters, with sluggish global demand and protracted trade policy uncertainty. The negative impact of subdued manufacturing activity and exports on growth has been partly mitigated by still robust private consumption across much of the region and import compression. Many countries, including China, have increased monetary and fiscal policy support in response to these less favorable external conditions.

\section{FIGURE 2}

Regional growth has also slowed amid challenging external conditions

GDP, y/y, Percentage

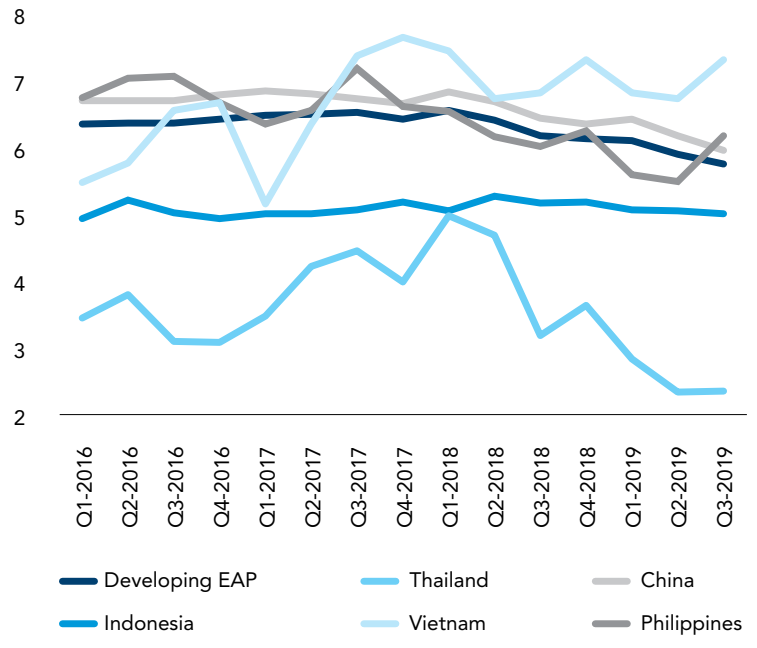

Source: World Bank Global Economic Prospects 


\section{Malaysia's economy continues to expand, but at a more moderate pace}

The Malaysian economy expanded at 4.4 percent in Q3 2019, moderating from 4.9 percent recorded in Q2 2019 (see Figure 3). Economic growth was mostly supported by private consumption and net exports due to import compression, contributing a combined 5.1 percentage points to GDP growth in Q3 2019 (see Figure 4). The contraction in overall investment, however, continued to weigh on growth during the quarter.

Private consumption remained the largest contributor to output growth. Private consumption expanded at a lower but still robust rate of 7 percent in Q3 2019 (Q2 2019: 7.8 percent), and contributed 4.1 percentage points to output growth. Household consumption spending continued to be supported by moderate inflation and continued private sector employment and wage growth. Public consumption gained some momentum in Q3 2019, expanding by 1 percent, up from 0.3 percent in Q2 2019.

Gross fixed capital formation (GFCF) contracted for the third consecutive quarter, owing to weakerthan-expected business investment growth and continued contraction in public investment. Private

FIGURE 3

Malaysia's economic growth slowed in Q3 2019...

GDP, y/y, Percentage

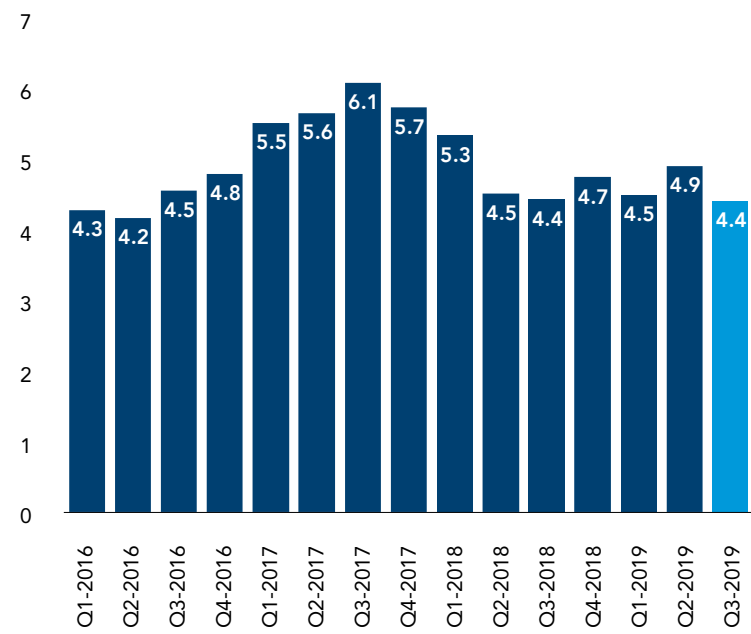

investment growth slowed to 0.3 percent in Q3 2019 (Q2 2019: 1.8 percent), weighed down by challenging external conditions and subdued business confidence. Most key types of investment were affected by the decline in capital expenditure, including investment in structures and in machines and equipment, which contracted by 2.4 percent (Q2 2019: 1.2 percent) and 7.4 percent (Q2 2019: -4.2 percent) respectively during the quarter. The business condition index has remained below 100 (signifying contraction) for the past 12 months. Meanwhile, public sector investment contracted further by 14.1 percent in Q3 2019 (Q2 2019: -9.0 percent), as several major public infrastructure projects remained under review and those that are expected to resume have not yet started.

On the supply side, there was a broad deceleration across the services, manufacturing and agriculture sectors, with contractions in mining and construction sectors. The growth rate in the services sector moderated further to 5.9 percent in Q3 2019 (Q2 2019: 6.1 percent), with slower growth observed in most major subsectors. After a moderate rebound in Q2 2019, manufacturing output declined to 3.6 percent in Q3 2019 (Q2 2019: 4.3 percent),

\section{FIGURE 4}

...weighed down by negative investment growth
Contribution to GDP, $y / y$, Percentage

8

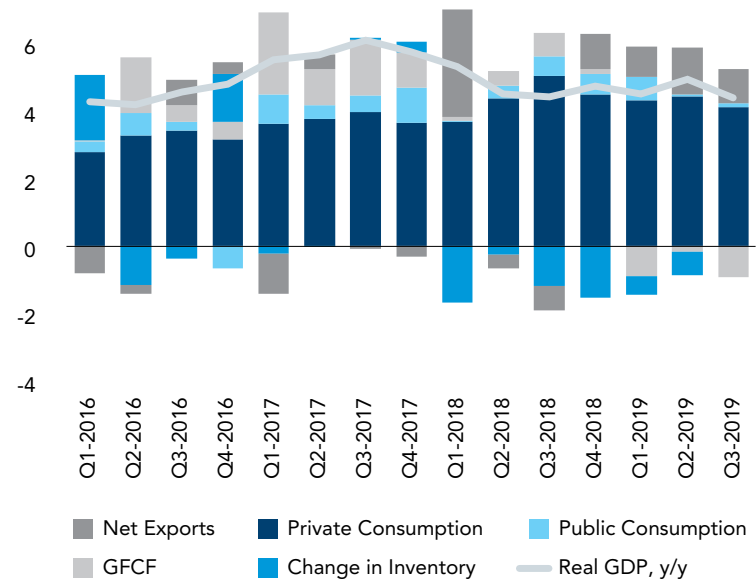


mainly due to weak global demand, which weighed heavily on the production of electric and electronic (E\&E) equipment. In the agricultural sector, the strong expansion in rubber, livestock and marine fish production was offset by the continued contraction in forestry and aquaculture output. The robust rebound in mining and quarrying recorded in the previous quarter was not sustained. Output shrank by 4.3 percent, compared to the 2.9 percent growth recorded in Q2 2019, owing mainly to the unplanned maintenance shutdowns of several oil production operations across Malaysia. In the construction sector, production declined by 1.5 percent in Q3 2019 (Q2 2019: 0.5 percent), due to deeper contractions in the residential and nonresidential subsectors amid an oversupply of commercial buildings and residential properties. See Box 1 for a broader discussion of Malaysia's potential growth.

Leading economic indicators suggest the Malaysian economy will continue to expand at a moderate pace in the near term. Both the consumer confidence and business condition indices, from the Malaysian Institute of Economic Research (MIER), have remained below 100 since Q4 2018, indicating subdued confidence in the economy. Meanwhile, the Industrial Production Index (IPI) has been declining continuously on a month-to-month basis since May 2019, in line with the broad slowdown in key sectors of production.

\section{TABLE 1}

\section{GDP growth decomposition}

GDP, y/y, Percentage

$\begin{array}{ccccccccccc}\mathrm{Q} 3 & \mathrm{Q} 4 & 2017 & \mathrm{Q} 1 & \mathrm{Q} 2 & \mathrm{Q} 3 & \mathrm{Q} 4 & 2018 & \mathrm{Q} 1 & \mathrm{Q} 2 & \mathrm{Q} 3 \\ 2017 & 2017 & & 2018 & 2018 & 2018 & 2018 & & 2019 & 2019 & 2019 \\ 6.1 & 5.7 & 5.7 & 5.3 & 4.5 & 4.4 & 4.7 & 4.7 & 4.5 & 4.9 & 4.4\end{array}$

$\begin{array}{llllllllllll}\text { GDP } & 6.1 & 5.7 & 5.7 & 5.3 & 4.5 & 4.4 & 4.7 & 4.7 & 4.5 & 4.9 & 4.4\end{array}$

\begin{tabular}{lcccccccccccc}
\hline Consumption & 7.1 & 6.9 & 6.9 & 6.6 & 7.9 & 8.9 & 8.4 & 8.0 & 7.6 & 7.8 & 7.0 \\
\hline \multicolumn{1}{c}{ Private Sector } & 4.0 & 6.9 & 5.5 & 0.4 & 3.1 & 5.2 & 4.0 & 3.3 & 6.3 & 0.3 & 1.0 \\
\hline Public Sector & 6.6 & 4.4 & 6.1 & 0.4 & 1.6 & 2.8 & 0.6 & 1.4 & -3.5 & -0.6 & -3.7 \\
\hline Gross Fixed Capital Formation & 10.6 & 5.1 & 8.7 & 2.4 & 2.6 & 0.7 & 3.1 & 2.2 & 0.1 & 0.1 & -1.4 \\
\hline Exports of Goods \& Services & 12.2 & 6.2 & 10.2 & -2.3 & 3.6 & 2.0 & 1.8 & 1.3 & -1.4 & -2.1 & -3.3 \\
\hline Imports of Goods \& Services & & & & & & & & & & & \\
\hline
\end{tabular}

\begin{tabular}{lccccccccccc}
\hline Sectoral & & & & & & & & & & \\
\hline Agriculture & 3.1 & 9.3 & 5.8 & 3.1 & -1.7 & -0.8 & -0.1 & 0.1 & 5.6 & 4.2 & 3.7 \\
\hline Mining & 2.3 & -0.9 & 0.4 & -0.6 & -3.4 & -5.7 & -0.7 & -2.6 & -2.1 & 2.9 & -4.3 \\
\hline Manufacturing & 7.0 & 5.3 & 6.0 & 5.2 & 4.9 & 5.0 & 4.7 & 5.0 & 4.1 & 4.3 & 3.6 \\
\hline Construction & 6.2 & 5.9 & 6.7 & 4.9 & 4.8 & 4.7 & 2.6 & 4.2 & 0.3 & 0.5 & -1.5 \\
\hline Services & 6.5 & 6.2 & 6.2 & 6.5 & 6.5 & 7.3 & 6.9 & 6.8 & 6.4 & 6.1 & 5.9 \\
\hline
\end{tabular}

Source: World Bank staff calculations based on DOSM data 


\section{Malaysia's output gap and potential growth}

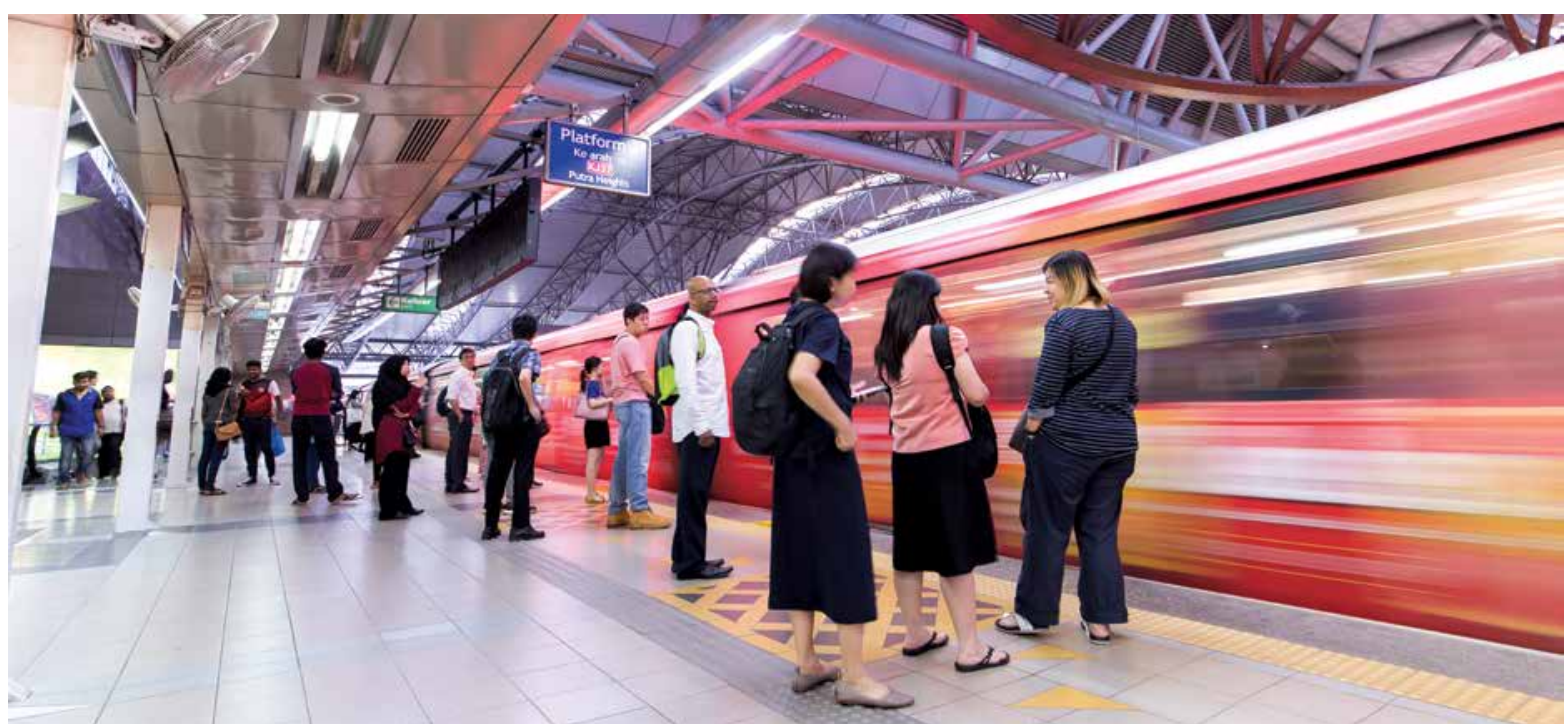

The output gap measures the difference between what an economy is producing and what it could efficiently produce at full capacity (potential output). As a concept, it is synonymous with the business cycle-the ups and downs, expansions and contractions, or booms and busts that happen over a number of years. This places the output gap at the heart of macroeconomic policy choices. Arthur Okun referred to it as "the point of balance between more output and stability" (Okun 1970). Knowing where the output gap is and where it is going empowers monetary policy makers to react appropriately to the inflation that it creates. For fiscal policymakers, an understanding that an economy is running above its capacity suggests that additional revenue should be saved and that expenditure should not be expanded to match revenue growth, as this growth is unlikely to be sustained. By contrast, when downturns occur, an understanding that an economy is running below capacity suggests that there is a need to increase expenditure to support growth.

Neither the output gap nor potential growth are directly observable and therefore need to be estimated. Numerous approaches and variations on these approaches can be used to estimate the output gap. Ultimately, estimating this gap involves an endeavor to isolate the cyclical part of output from the trend. Filtering techniques form the foundation for this work, including the use of Hodrick-Prescott and Kalman filters. The multivariate filter model used in this box estimates the output gap based on the Kalman filter. It exploits the information available in other measures of capacity, including capacity utilization and unemployment. Given that Malaysia is an open economy, the model is extended to include a measure of the foreign output. Potential growth is estimated using a Cobb-Douglas production function approach in which potential growth is decomposed into its inputs (labor, capital and total factor productivity).

Since the nadir of the global recession, when Malaysia's output gap stood at -6.2 percent, this gap has ebbed and flowed around potential growth (see Figure 5). The output gap has remained range-bound since 2011, not deviating by more than 1 percentage point from zero (when accounting for uncertainty, it was not statistically different from zero). Real GDP growth remained equally bound in the range of 4 to 6 percent over much of this period. It slowed during the euro area crisis in 2013; over the course of 2015 and 2016 as oil prices collapsed and EMDEs in general experienced slowing growth; and more recently, since the start of 2018, generating negative output gaps. In the third quarter of 2019, the output gap is currently estimated at -1.1 percent of potential output, from an average of -0.2 percent in 2018. 
FIGURE 5

Malaysia's output gap turned negative in the second quarter of 2018...

Percentage of Potential Output

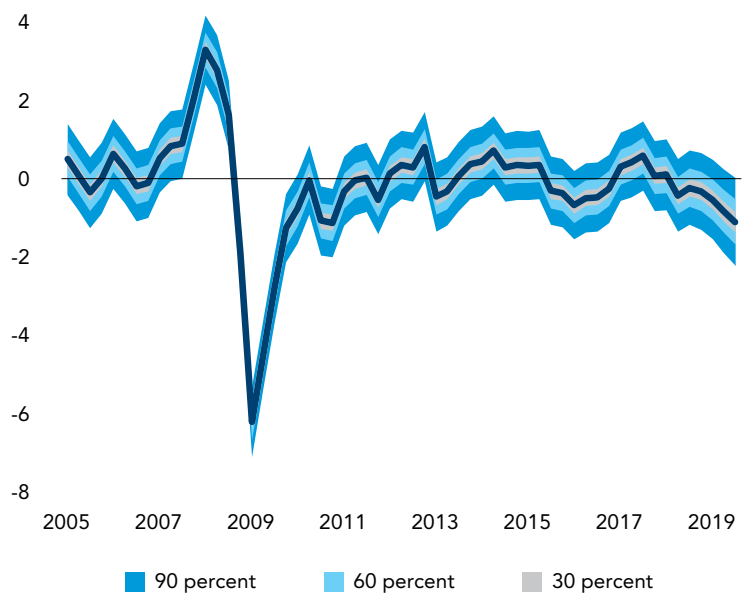

Source: World Bank staff calculations using Haver

Note: Based on estimates from a modified Multivariate Filter model as in World Bank (2018a). A foreign output gap is added to Malaysia's output gap equation given the open nature of the economy. Foreign output gap is measured as the export weighted average of Malaysia's top ten export destinations between 2016 and 2018 .

\section{FIGURE 7}

Output gaps can vary by method...

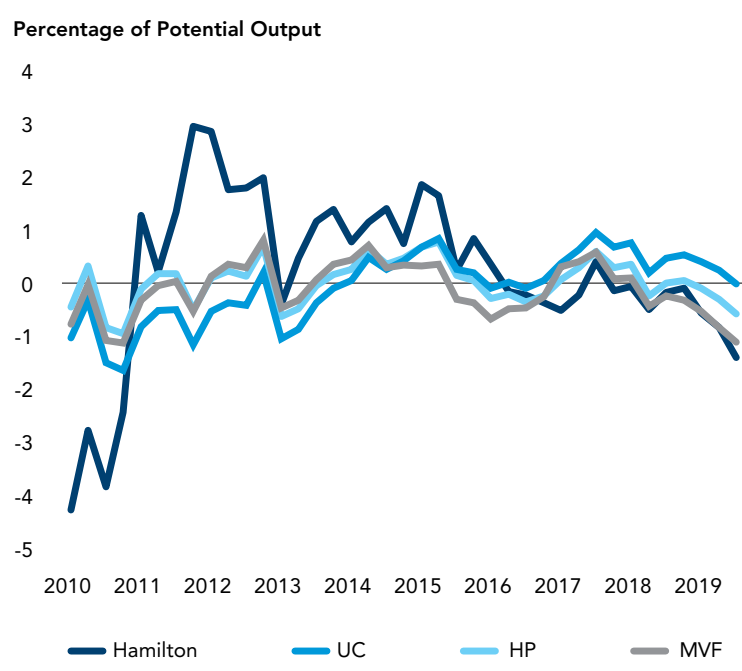

Source: World Bank staff calculations using Haver

Note: Hamilton refers to the methodology proposed by Hamilton (2018) -an autoregressive model with $p=4$ (number of lags) and $h=8$ (horizon). $\mathrm{HP}=$ Hodrick-Prescott Filter, UC = Unobserved Components model, and $\mathrm{MVF}=$ Multivariate Filter model. See Chapter 3 of World Bank (2018a) for details.

\section{FIGURE 6}

...as asset prices and credit expansion slowed

Percentage of Potential Output

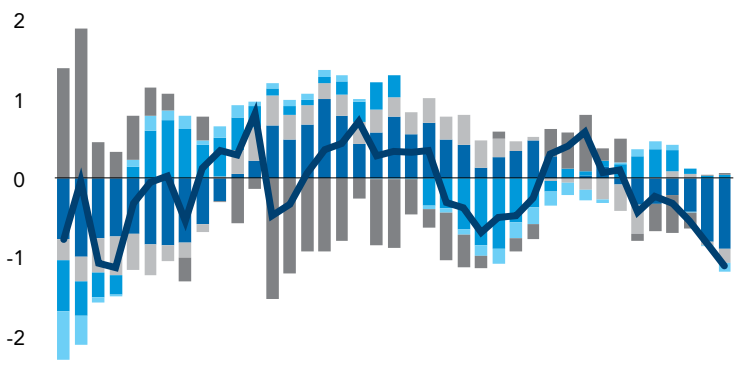

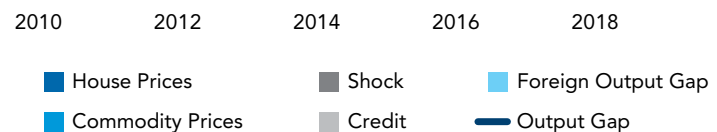

Source: World Bank staff calculations using Haver

Note: Recursive decomposition of the output gap equation. Unlike a shock decomposition, only variables in the output gap equation are decomposed.

\section{FIGURE 8}

...although potential growth has been robust

Percentage

10

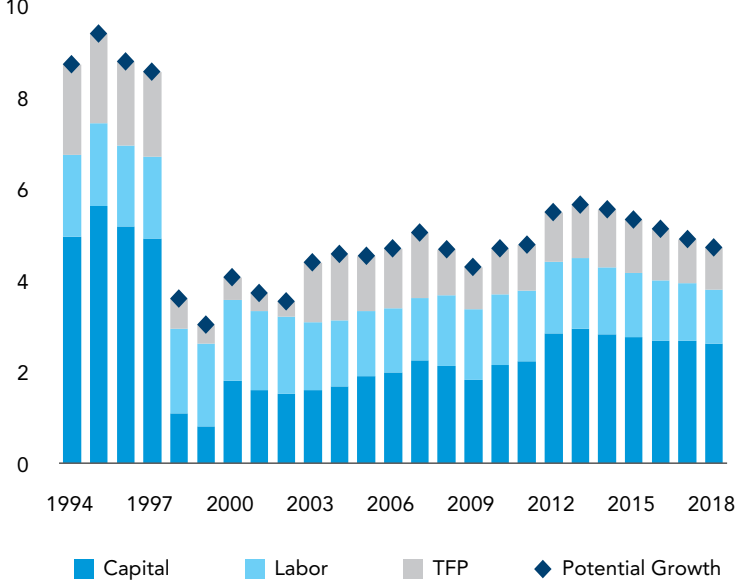

Source: World Bank staff calculations using Haver

Note: Potential growth estimates based on production function approach as in World Bank (2018a). TFP stands for total factor productivity. 
Many drivers affect the output gap. Along with capacity utilization, inflation, and the unemployment rate (which are used in the multivariate filter model to identify the output gap), other measures that affect it directly include credit extension, house price growth, commodity prices and the foreign output gap. These can be recursively decomposed to identify the drivers of the output gap (see Figure 6).

In particular, house prices and commodity prices have played a prominent role since 2011. The Malaysian housing market significantly affects the economy, accounting for the majority of the above 80 percent household debt to GDP. Following the 1998 Asian crisis, house prices in Malaysia remained relatively stable, growing by the average annual rate of 1.5 percent in the period from 2000 to 2010. Over this period, house prices contributed negatively to the output gap. By 2011, however, the housing market had begun to boom, with house price growth reaching an average annual rate of close to 9 percent in the period from 2011 to 2014. This strong performance, driven in part by demand by non-residents, was reflected in the output gap, with house prices contributing to up to 1 percentage point of the gap at the peak of the boom in 2013. In response, Malaysian authorities implemented macroprudential measures, with measures to increase the availability of affordable housing to help dampen the market. House price growth has subsequently slowed, with the rate at 1.5 percent in Q1 2019 on an annual basis. Since 2018, its contribution to the output gap has turned negative.

Commodity price developments have also contributed to developments in the output gap. Following the rebound from the global recession, strong oil prices resulted in commodity prices contributing positively to the output gap through 2015. The subsequent collapse of oil prices saw commodity prices begin to drag on the output gap, with the contribution reaching a nadir of -0.9 percentage point by mid-2016. Since then, commodity prices have recovered somewhat and currently are not a significant driver of the output gap.

While the output gap is not directly observable, it can be estimated using a number of approaches. To establish some degree of confidence in its position, the results from the use of multiple methods can be compared (see Figure 7). Three alternative filtering techniques are presented here and although there can be significant differences, most measures tend to co- move and cluster well. The methods are well correlated, with the weakest correlation between the multivariate filter model and the approach implemented by Hamilton (2018), at 0.85 . Three of the four methods presented here suggest that Malaysia has had a negative and widening output gap since mid-2018.

Potential growth in Malaysia has declined significantly, from around 9 percent during the preAsian crisis period to less than 4 percent during post-Asian crisis period (1998-2001) (see Figure 8). Until recently, it was on an upward trend, reaching an average level of 5.1 percent over the past five years, despite some downturns during the global financial crisis. Capital stock has been the principal driver of the potential growth in Malaysia, contributing to almost half on average in the period from 1994 to 2018. Despite the recent slowdown in investment growth, especially after 2012, the contribution of capital stock is still robust, standing at 2.6 percentage points in 2018 . Total factor productivity growth has remained steady over the past 15 years, with the average annual rate standing at around 1.1 percent. Improvements to education and intensified efforts to increase female labor force participation will be required to boost potential growth into the future.

With the deteriorating global economy, risks to Malaysia's growth prospects are increasing. With Malaysia being both a highly open economy and a commodity exporter, it will not be spared if global conditions worsen and risks materialize. For policy makers to appropriately implement countercyclical monetary and fiscal policy, they must have a good understanding of the demand side of the economy, which is provided by the output gap. Accurate forecasts of the direction of the output gap can ensure that policy is appropriately calibrated. On the supply side of the economy, an understanding of potential growth dynamics and the drivers of potential growth may help policymakers prioritize structural reforms that can ultimately boost long-term growth prospects. On these, the analysis suggests that boosting Malaysia's human capital, particularly increasing the quality of education and the level of female labor force participation, are likely to have a greater impact on potential growth. 


\section{Export growth was affected by weaker global trade}

The decline in export demand continued to deepen in the context of softening global growth and international trade. With weaker external demand and heightened trade policy uncertainty, exports of goods and services shrank by 1.4 percent in Q3 2019 (Q2 2019: 0.1 percent). Malaysia's exports of manufactured goods moderated, owing largely to a significant growth decline in E\&E exports. This was partially offset by a surge in the exports of other product groups, including transport equipment, machinery parts and iron and steel products. Meanwhile, commodities exports contracted due to a notable decline in petroleum exports, resulting from the temporary closure of several major oil fields for maintenance. While there is continued evidence that Malaysia is picking up some market share in China and the US as a result of tariffs imposed by the two countries (see Box 2), any such gains resulting from trade diversion appear to now be offset by a generalized slowdown in global growth and international trade.

Imports of goods and services contracted for the third consecutive quarter. The decline in goods and services imports intensified in Q3 2019, with the rate sinking to -3.3 percent (Q2 2019: -2.1 percent). Consistent with the further contraction in gross capital formation, imports of capital goods registered a steeper decline of 15.4 percent (Q2 2019: -8.9 percent), led by a decrease in the imports of machinery and transport equipment. The imports of intermediate goods also

\section{FIGURE 9}

\section{Export growth has turned negative amid} softening global demand

Contribution to Export Growth, y/y, Percentage

25

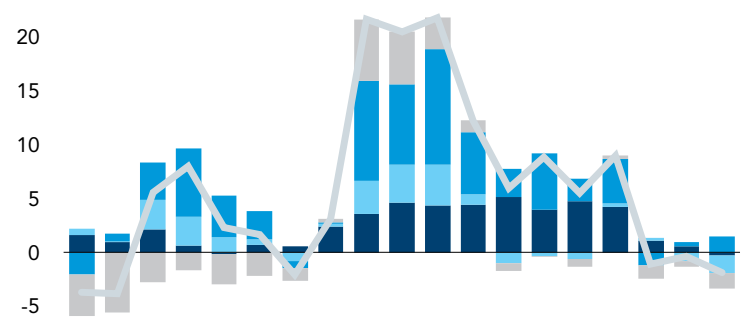

$-10$

敢

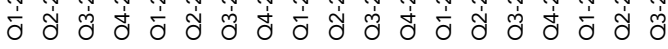

$$
\begin{aligned}
& \text { E\&E - Semiconductors } \quad \text { E\&E - Others Exports, } y / y \\
& \text { Non-E\&E }
\end{aligned}
$$

Source: World Bank staff calculations based on BNM and DOSM data contracted during the quarter (Q3 -3.0 percent; Q2 2019: 6.8 percent), in line with the weakening demand for manufactured exports.

The current account surplus narrowed to 3 percent of GDP in Q3 2019 (Q2 2019: 3.8 percent), due to increased primary and secondary income deficits (see Figure 10). With the decline in imports of goods outstripping the decline in exports, the trade in goods surplus increased to RM30.8 billion in Q3 2019 (Q2 2019: RM28.1 billion). After widening in Q2 2019, the deficit in the services account narrowed to 0.4 percent of GDP (Q2 2019: -0.9 percent). This smaller deficit is attributable to an increase in tourism receipts due to a surge in international tourist arrivals. The increase in the deficit of the secondary income account was modest (Q3 2019: -1.4 percent; Q2 2019: -1.3 percent), while the deficit in the primary income account more than doubled compared to the previous quarter (Q3 2019; -3.2 percent; Q2 2019: -1.5 percent). This increase in the primary income deficit was largely due to a decline in investment income from abroad by Malaysian companies, while remittance outflows continued to drive the secondary income deficit. There was a reduced net outflow in the financial account due to a narrower net outflow in foreign direct investments (FDI) and a net inflow in financial derivatives and other investment types. Meanwhile, the net outflow of portfolio investment increased to 7 percent of GDP, compared to a deficit of 2.7 percent in Q2 2019.

\section{FIGURE 10}

A larger income deficit led to a decline in the current account surplus

Current Account Balance, Percentage of GDP

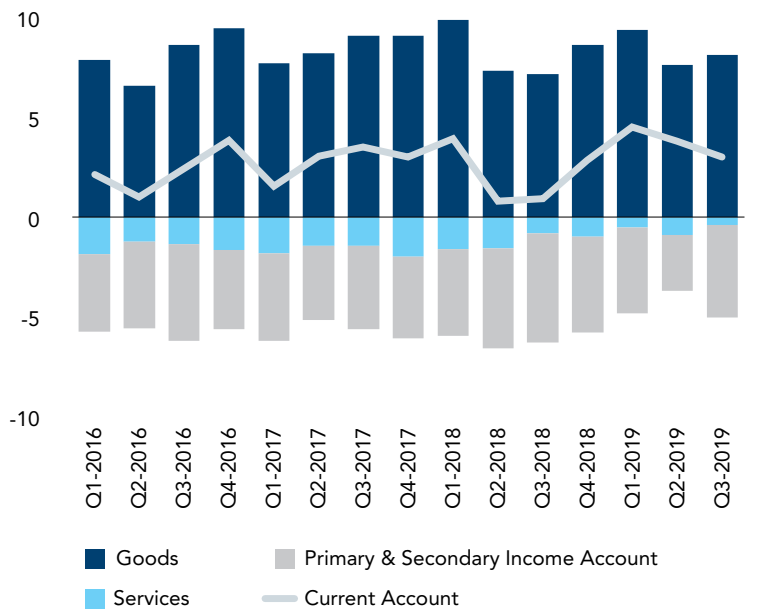

Source: World Bank staff calculations based on DOSM data 


\section{The impact of US-China trade tensions on Malaysia's exports}

\begin{abstract}
With bilateral trade between the US and China declining since the implementation of tariffs, Malaysia's exports to the US and China of products targeted by tariffs have increased. This suggests that Malaysia is deriving some short-term benefits from the US-China tensions as a result of trade diversion, even if overall demand for Malaysia's exports is weakening in the content of slowing global growth. It also points to the underlying competitive strength of the Malaysian economy.
\end{abstract}

Malaysia's exports of tariff-affected products to the U.S. and China have increased in value by more than US\$2 billion since the tariffs were imposed. An analysis of trade data shows gains in the US market of US $\$ 0.25$ billion, reflecting an increase by 0.8 percent in Malaysia's exports of the affected goods to the US relative to the pre-tariff period, and gains in the Chinese market of US $\$ 2.02$ billion, reflecting an increase by about 9 percent in Malaysia's exports of the affected goods to China relative to the pre-tariff period. These statistics are derived from an examination of US and Chinese imports from Malaysia of products on eight US and Chinese lists of goods affected by tariffs, which the two countries have imposed on each other over this period. Specifically, the imports from Malaysia for such products in the period following the tariff implementation is compared to imports in the corresponding period a year ago ${ }^{2}$.

Most of the increase in Malaysia's tariff-affected exports to the U.S. and China has been driven by the increased exports of few products (see Figure 11). In particular, the increases in Malaysia's exports of semiconductors and electronic integrated circuits, including processors and controllers (on which tariffs were imposed in August 2018) appear to account for the majority of its increased exports to the US market. Malaysia's exports of products on US List 3 have declined and there was negligible increase in the overall exports of other products (including those on

\section{FIGURE 11 \\ Malaysia is experiencing some short-term gains from trade diversion}

Year-on-year change in US and Chinese imports from Malaysia of tariff-affected products after tariff implementation, US\$ billion

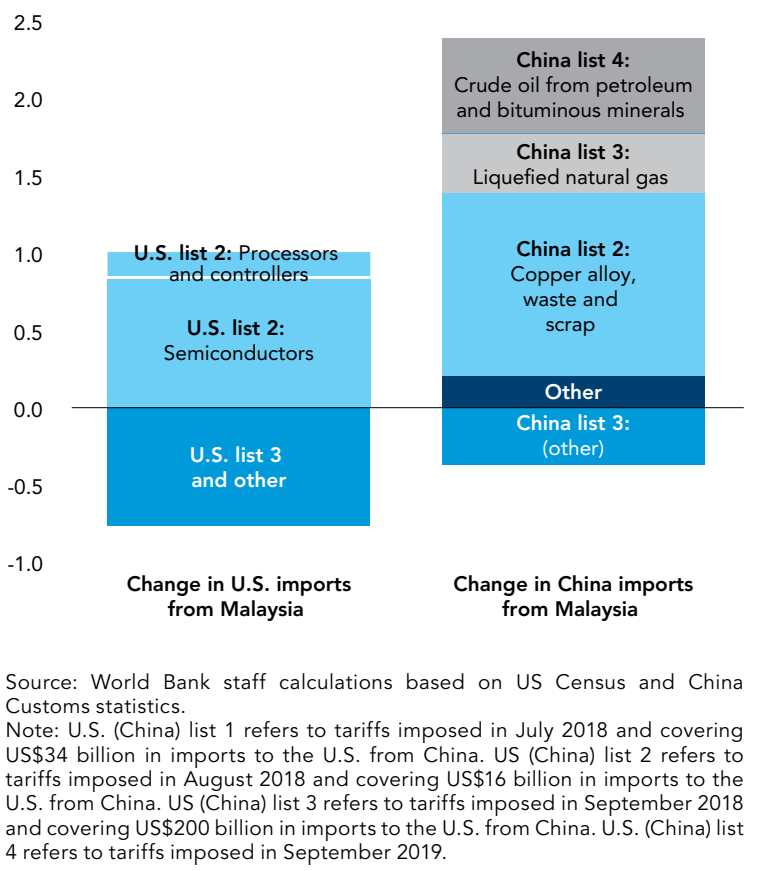

US List 1 and US list 4, and those on US List 2 apart from semiconductors and electronic integrated circuits). By contrast, the gains in the Chinese market are primarily driven by exports of copper waste and scrap (China List 2), liquefied natural gas (China List 3) and, based on preliminary evidence, crude oil from petroleum and bituminous minerals (China List 4). There has also been an increase in exports of products on China List 1 , other products (apart from copper waste and scrap) on China List 2 and other products (apart from crude oil) on China List 4. There has been a decline in exports of other products (apart from liquefied natural gas) on China List 3.

2 The analysis compares the effect of tariffs implemented in July, August and September 2018, as well as September 2019. The authors compare August 2018-September 2019 with August 2017-September 2018, for products on US and China lists 1 implemented in July; September 2018-September 2019 with September 2017-September 2018 for products on US and China lists 2 implemented in August; January-September 2019 with January-September 2018 , for products on US and China lists 3 implemented in September 2018; and September 2019 with September 2018, for products on US and China lists 4 implemented in September 2019. For list 3, the last quarter of 2018 is excluded due to continued year on year growth of US imports of from China, in anticipation of a tariff hike from 10 percent to 25 percent. 
TABLE 2

Selected external sector indicators

$\begin{array}{ccccccccc}\text { Q3 } & \text { Q4 } & \text { Q1 } & \text { Q2 } & \text { Q3 } & \text { Q4 } & \text { Q1 } & \text { Q2 } & \text { Q3 } \\ 2017 & 2017 & 2018 & 2018 & 2018 & 2018 & 2019 & 2019 & 2019\end{array}$

\begin{tabular}{|lcccccccccc}
\hline Balance of Goods \& Services (\% of GDP) & 7.7 & 7.1 & 8.3 & 5.8 & 6.4 & 7.6 & 8.8 & 6.6 & 7.6 \\
\hline $\begin{array}{l}\text { Current Account Balance (\% of GDP) } \\
\text { Total Exports (\% of GDP) }\end{array}$ & 3.5 & 3.0 & 3.9 & 0.8 & 0.9 & 2.9 & 4.5 & 3.8 & 3.0 \\
\hline Total Imports (\% of GDP) & 70.7 & 68.9 & 68.5 & 68.5 & 69.0 & 69.0 & 66.3 & 65.9 & 65.4 \\
\hline Net Portfolio Investment (RM billion) & -9.9 & 9.4 & -1.5 & -37.9 & 0.8 & -5.8 & 2.1 & -10.2 & -26.8 \\
\hline Gross Official Reserves (RM billion) & 427.8 & 414.7 & 416.4 & 423.4 & 427.0 & 419.6 & 420.3 & 425.5 & 431.3 \\
\hline (US\$ billion) & 101.2 & 102.4 & 107.8 & 104.7 & 103.0 & 101.4 & 103.0 & 102.7 & 103.0
\end{tabular}

\section{Inflation remains subdued, but base effects have pushed the rate higher}

In Q3 2019, the headline inflation rate increased to 1.3 percent (Q2 2019: 0.6 percent) reflecting the dissipating impact of the GST zeroization in the period from June to August last year (see Figure 12). During the period, inflation was

\section{FIGURE 12}

Headline inflation was higher in recent months...

Inflation, $y / y$, Percentage

6

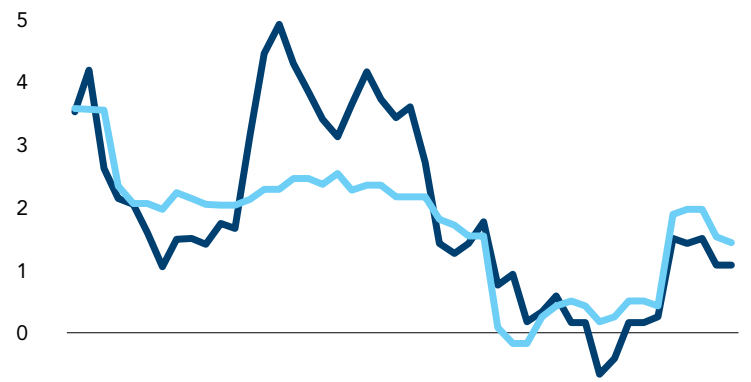

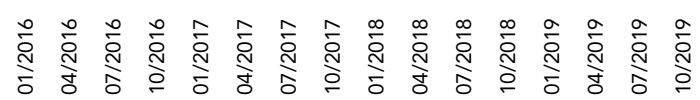
- Headline Inflation Core Inflation mainly driven by food and non-alcoholic beverages, together with furnishings, household equipment and routine household maintenance. The contribution of transport costs to headline inflation during the period was negative, due to lower fuel prices (see Figure 13).

\section{FIGURE 13}

...reflecting the lapse in the impact of GST zeroization last year

Contribution to Inflation, $y / y$, Percentage

6

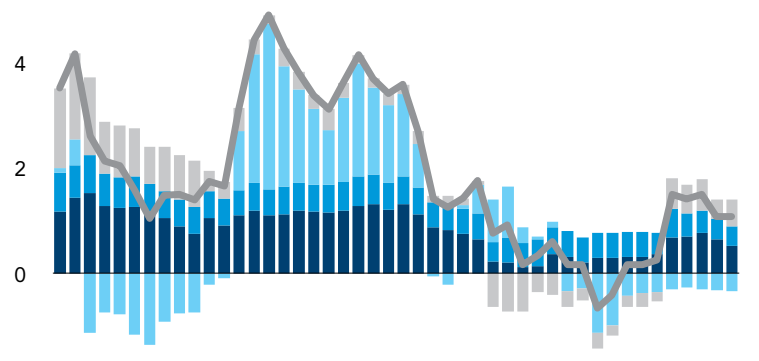

$-2$

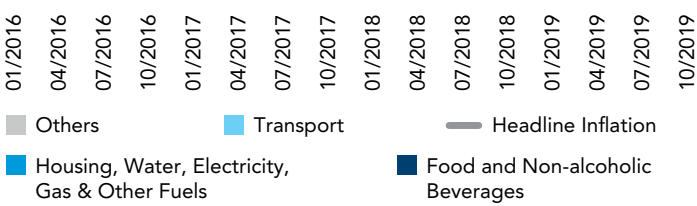

Source: World Bank staff calculations based on DOSM data 


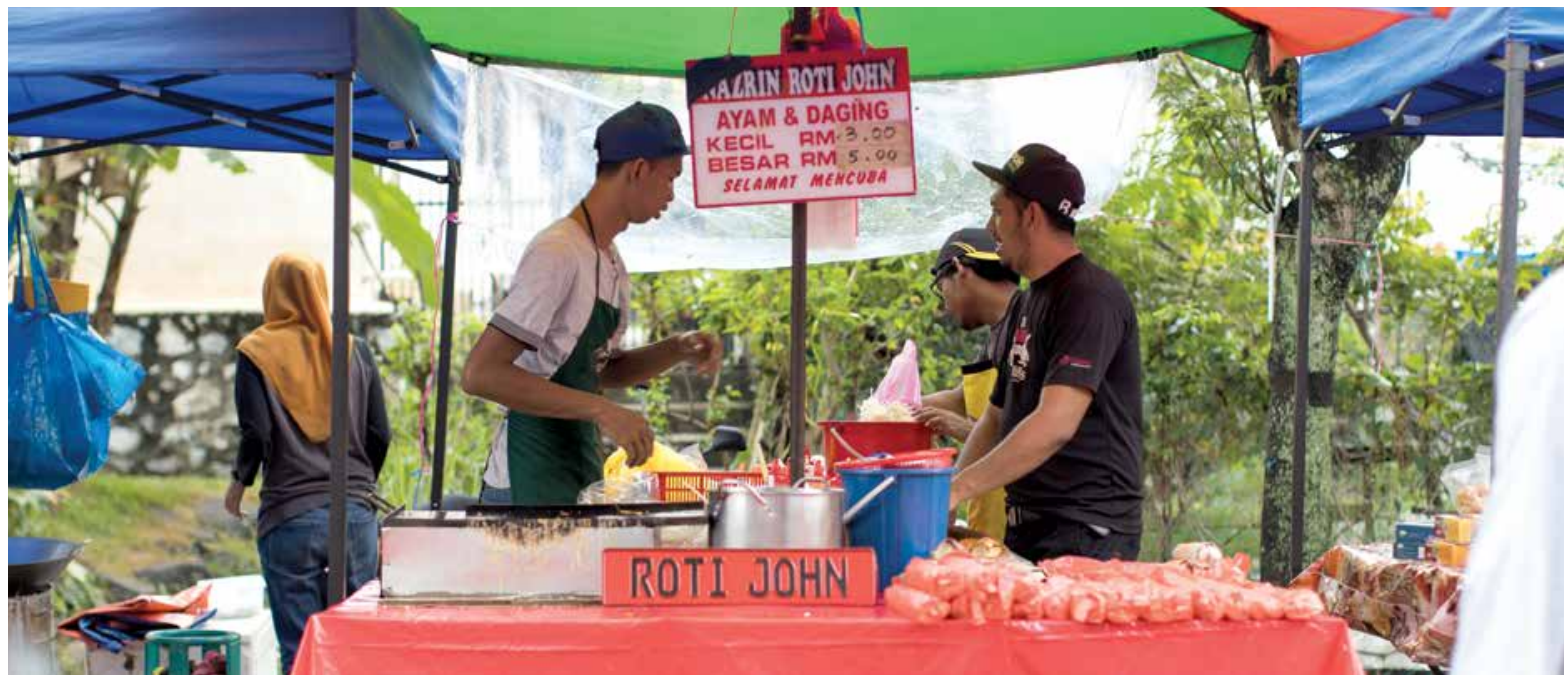

This reflected the decline in the RON97 petrol price in the context of lower average global oil prices (average RON97 petrol price per liter Q3 2019: RM2.56; Q2 2019: RM2.65). Comparing inflation trends across regions, the inflation rate was higher than the national average in more urbanized states such as Kuala Lumpur, Penang and Selangor. Over the period, measures of underlying inflation have remained subdued. In Q3 2019, the core inflation rate, excluding the direct impact of consumption tax policy changes, remained stable at 1.5 percent in Q3 2019 (Q2 2019: 1.6 percent).

Conditions in the labor market have remained broadly stable. In Q3 2019, the labor force participation

\section{FIGURE 14}

Labor market conditions have remained broadly stable...

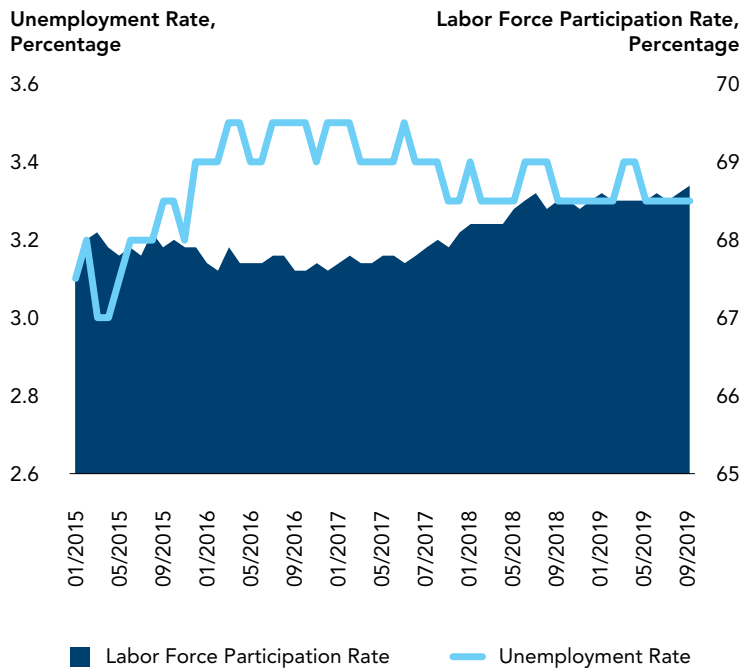

rate was estimated at 68.9 percent (Q2 2019: 68.8 percent) and the unemployment rate was unchanged at 3.3 percent (see Figure 14). The unemployment rate for those aged between 15 to 24 years, however, continues to be high at 10.2 percent during the quarter (Q2 2019: 10.4 percent) (see Figure 15). Meanwhile, the female labor force participation rate increased marginally, from 55.8 percent in Q2 2019 to 56 percent in Q3 2019. For two consecutive quarters, wage growth in the services sector (Q3 2019: 4.1 percent; Q2 2019: 4.4 percent) was higher than wage growth in the manufacturing sector (Q3 2019: 3.2 percent; Q2 2019: 3.9 percent). See Box 3 for a discussion of the linkages between inflation and labor markets in Malaysia.

\section{FIGURE 15}

...however the unemployment rate among those aged 15-24 years remains high

Unemployment Rate, Percentage

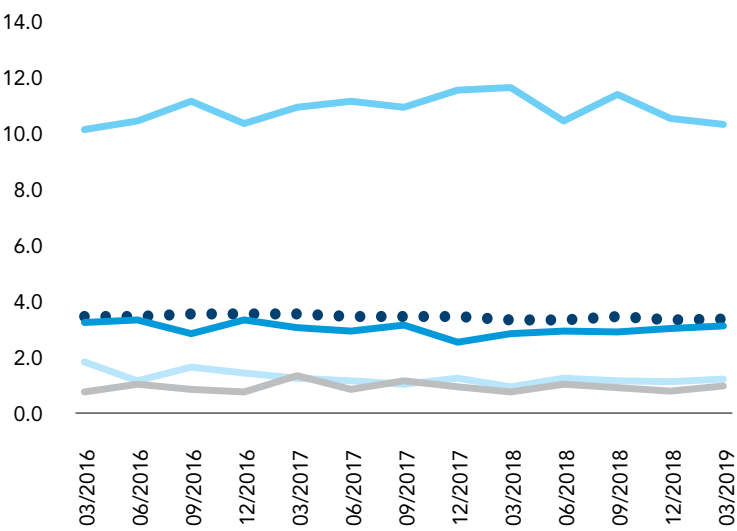

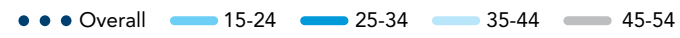




\section{Examining the links between inflation and the labor market in Malaysia}

The Phillips Curve describes the trade-off in economic theory between inflation and unemployment. When inflation is high, unemployment is expected to be low, and vice versa. The intuitive assumption behind the Phillips Curve is that when unemployment is low, employers will offer higher wages to attract scarce labor, potentially leading to higher inflation. In Malaysia, a cursory glance at the relationship defined by Phillips Curve shows two features. Firstly, there are substantial movements in inflation rates that are not associated with movements in the unemployment rate (see Figure 16). Secondly, there seems to be only limited variability in the unemployment rate. This raises the question of whether the unemployment rate sufficiently measures labor market capacity, which is required for an effective assessment of the Phillips Curve in Malaysia.

\section{FIGURE 16}

Relative to inflation, unemployment is remarkedly stable

Inflation and Unemployment Rates in Malaysia, Percentage

6

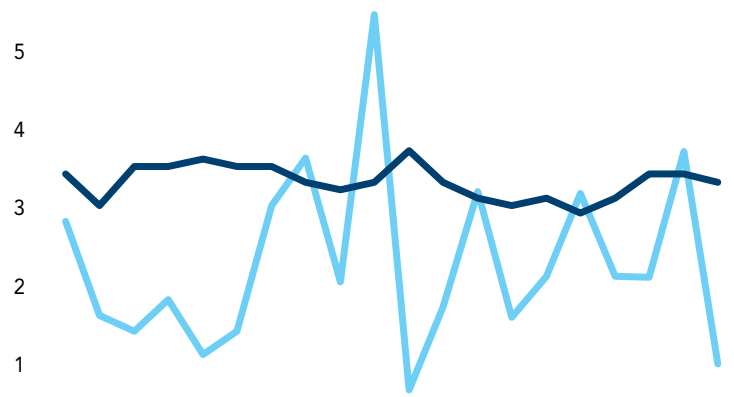

0

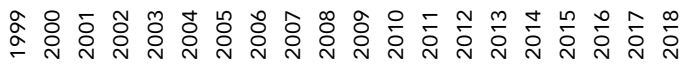
Unemployment $\longrightarrow \mathrm{CPI}$
While readily accessible, the headline unemployment rate has limitations and flaws as an indicator for labor market conditions. It is necessary to look beyond the aggregate unemployment rate and to unpack the information it might contain. To do this, we must first understand how the unemployment rate is computed. Figure 17 prompts us to consider not only the number of unemployed persons, but also the size of the labor force (the proportion of the working-age population who are either employed or unemployed).

Beyond the unemployment rate, changes in the labor force participation rate are also an important measure to assess labor market capacity. There is evidence that the employment needs of Malaysian businesses have been met through the entry of new participants to the labor force, rather than from the

\section{FIGURE 17}

Computation of the employment rate in Malaysia

Schematic Illustration, 2018

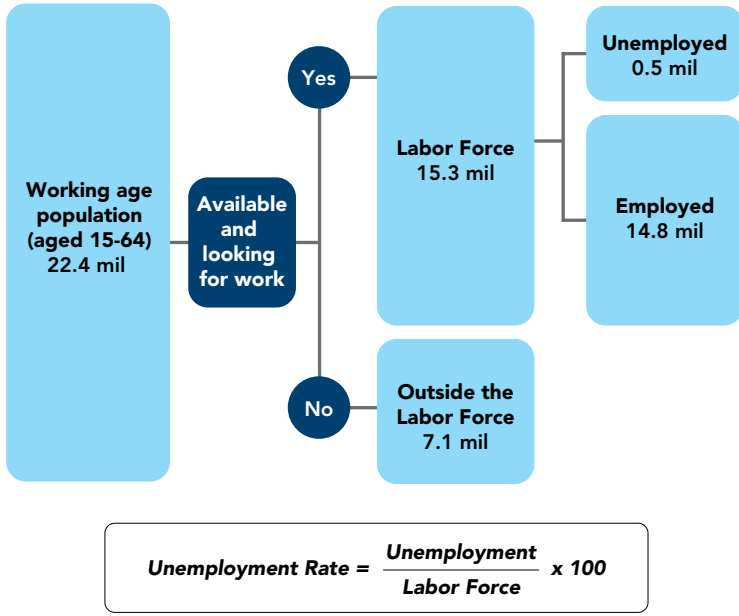

Source: World Bank staff based on DOSM data 
existing pool of available workers. Figure 18 compares the unemployment rate (the proportion of the labor force that is unemployed) and the employment rate (the proportion of the working-age population that is employed). In the period from 1983 to 1987, the unemployment rate increased steeply, by 3.6 percentage points, while the employment rate declined by only 2 percentage points. In this period, an inflow of entrants into the labor force found employment, even though the unemployment rate remained elevated. Similarly, the relatively steady unemployment rate after 1998, despite the large swing in the employment rate, meant that most of the movements in the latter were due to people joining the labor force and obtaining employment (see Figure 19). Therefore, it is important to monitor the movements in the labor force participation rate, and the factors affecting these movements. For instance, it is clear that for women, their involvement in housework and caring for the family constitutes the main factor constraining them from entering the labor force (see Box 5). Another group to monitor is the longterm unemployed, which is defined by the International Labor Organization (ILO) as the proportion of those actively searching for employment but unable to find it after more than one year. In 2018, the percentage of active long-term unemployed persons is low, at

\section{FIGURE 18}

\section{The employment rate has risen steadily during} recent years

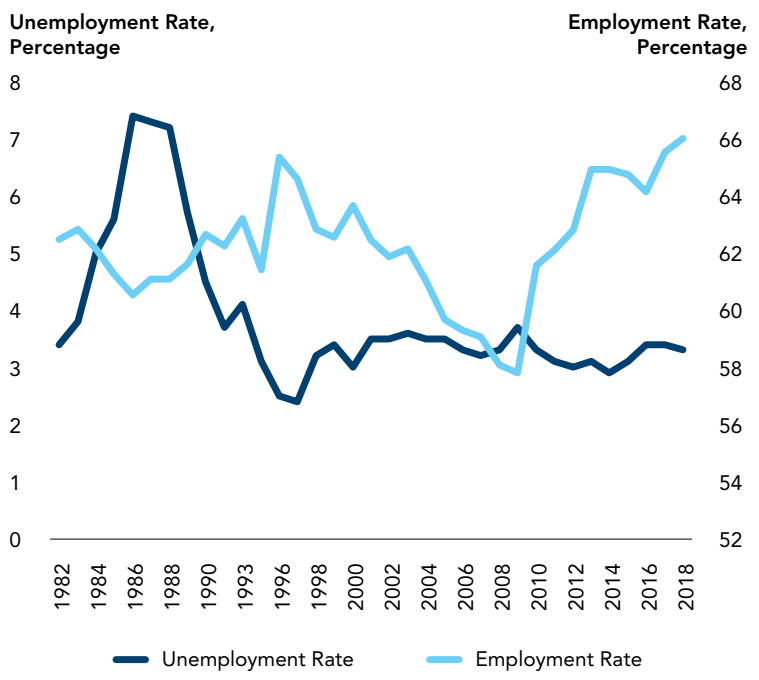

9.7 percent, but there is risk that many of them could become discouraged and end up exiting the labor force altogether.

The aggregate unemployment rate also masks the level of underemployment, which is also a crucial factor, reflecting the underutilization of the productive capacity of the employed population. The underemployed generally refers to workers whose jobs are mismatched with their availability to work, education or skill level. For instance, this group includes part-time workers who would like full-time jobs, or degree holders who only manage to find lowskilled jobs. A low headline unemployment rate may hide the fact that a significant portion of the workers view their employment as "unsatisfactory" in terms of hours, compensation, or use of their skills. As these workers continue to search for additional work hours or permanent or more highly skilled jobs, they compete with the unemployed in the search for employment, thus potentially exerting downward pressure on wages. In the case of Malaysia, the Department of Statistics Malaysia (DOSM) defines time-related underemployment in terms of the number of employees working less than 30 hours a week during the reference week. In the period from 2000 to 2018, such workers accounted

\section{FIGURE 19}

Labor force entry spikes were accompanied by higher employment rates

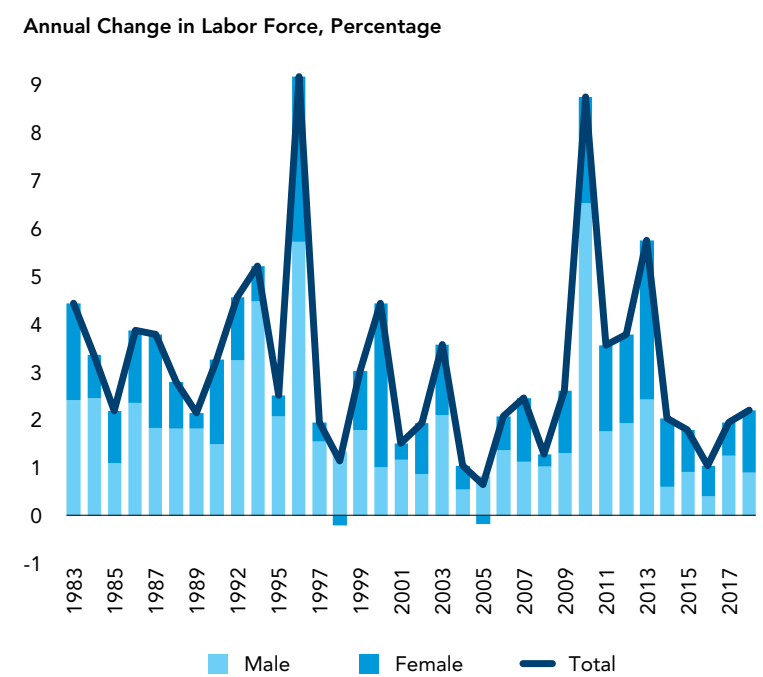

Source: World Bank staff based on DOSM data 


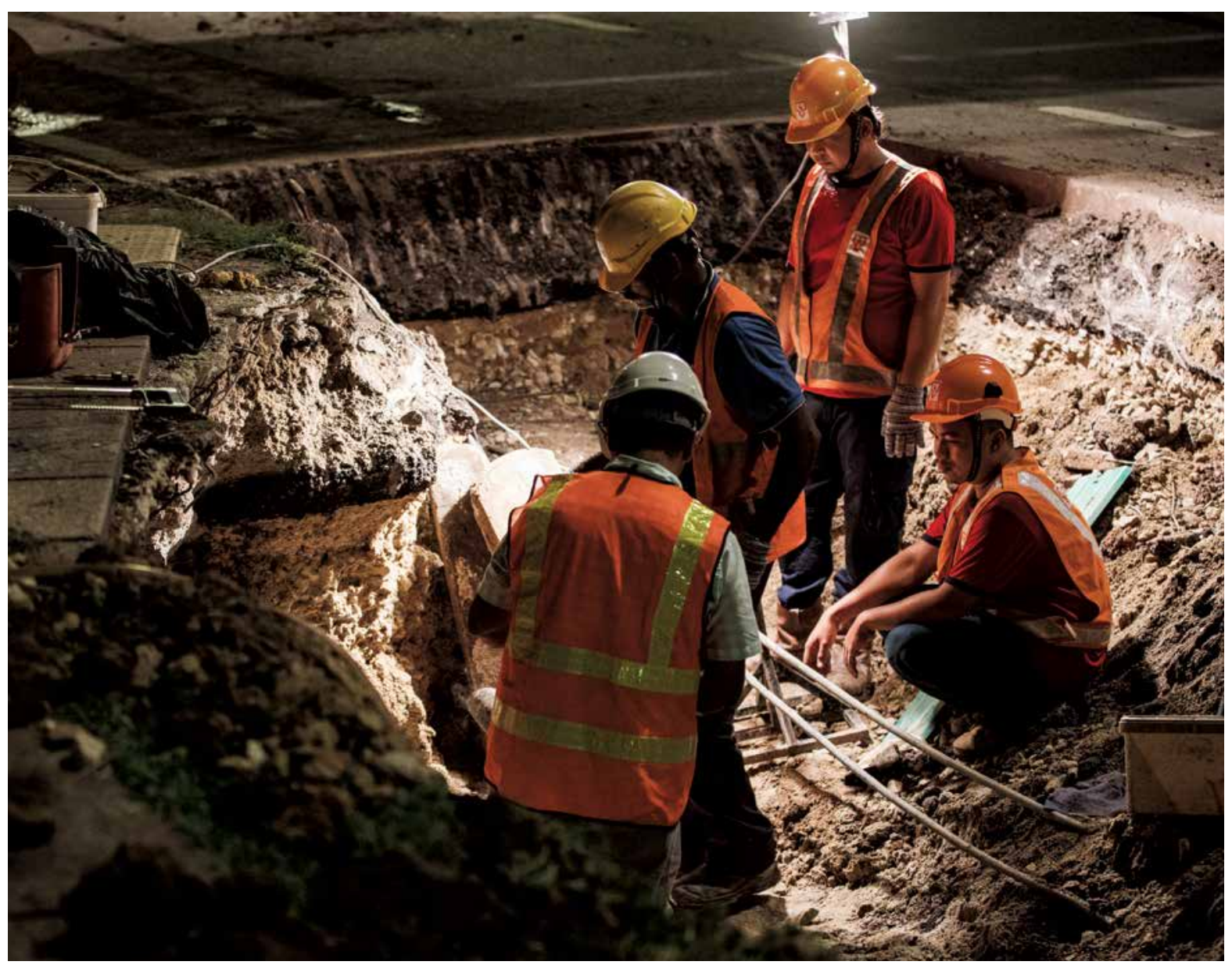

for 4.5 percent of the total employed workforce. While not very high, this data could provide a more accurate picture of labor market slack and its potential impact on wage and price pressures.

Another weakness of the official unemployment rate is that it under-calculates total foreign workers in Malaysia. The data for unemployment statistics collected by DOSM through the Labor Force Survey does include both citizens and non-citizens. However, it only covers persons staying in private living quarters, excluding workers in hostels and dormitories (where foreign workers in construction sites typically live). Therefore, the survey would not completely capture these foreign workers in some key sectors of the economy. While official statistics by the Ministry of Home Affairs report legal foreign workers to be approximately 2 million, World Bank estimates indicate that total foreign workers amount to approximately 3 million in 2017. Among these, the number of illegal foreign workers is estimated to be 1.2 - 1.5 million (World Bank, 2019b). At this high level, they may play a role in adjustments to labor market conditions in response to demand shocks.

In conclusion, relying solely on the headline unemployment rate could lead to the mismeasurement of labor slack, and hence the Phillips Curve of an economy. A broader and more detailed set of labor market statistics may be essential to monitor and analyze any potential wage pressures that may pass-through to inflation. Nevertheless, as the nuances of the unemployment rate explained in this article show, the starting point to comprehending economic relationships variables, including the Phillips Curve, is to understand the construction of these variables. Finally, in analyzing the connection between economic variables, it is helpful to remember Goodhart's Law, which warns policy makers against measuring statistical relationships around variables that are controlled by policies: "Any observed statistical regularity will tend to collapse once pressure is placed upon it for control purposes" (Goodhart, 1989). 


\section{Conditions in the financial system remain stable}

The Central Bank of Malaysia (Bank Negara Malaysia, BNM) maintained the overnight policy rate (OPR) at 3.00 percent, while lowering the statutory reserve requirement (SRR) ratio from $\mathbf{3 . 5 0}$ percent to $\mathbf{3 . 0 0}$ percent in November. In its most recent monetary policy statement in November 2019, BNM indicated that the domestic economy is expected to grow at a more moderate pace, with private consumption continuing to be the main driver of the economy supported by continued employment and wage growth. While exports will continue to be affected by slower global demand, this is expected to be mitigated by its diversified structure. BNM expects the economic growth rate to remain within its projections of 4.3 to 4.8 percent for 2019 , with the momentum continuing into 2020 . Risks continue to tilt to the downside, mainly stemming from uncertainties in global economic and financial conditions and to weaknesses in commodity-related sectors. During the same month, BNM lowered the SRR rate to 3.00 percent to maintain sufficient liquidity in the domestic financial system, and reiterated that the SRR is not a signal on the stance on monetary policy.

Financial soundness indicators indicate that Malaysia's banking system remains resilient in Q3 2019. As at end-September 2019, financial institutions

\section{FIGURE 20}

Net financing moderated on lower growth of bank loans and corporate bonds

Contribution to Net Financing Growth, y/y, Percentage

10

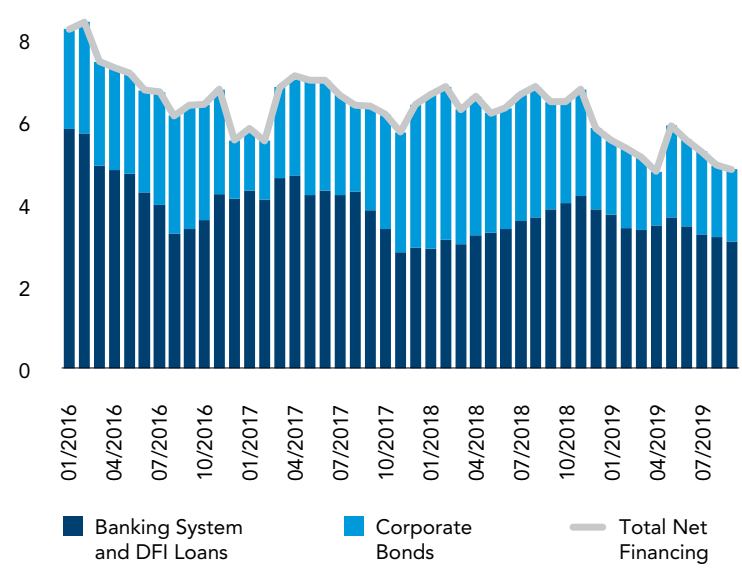

Source: BNM recorded sound levels of profitability, with a return on equity rate of 12.9 percent (end-June 2019: 13.0 percent) for the banking sector as a whole. The banking system's liquidity levels remain sufficient to support financial intermediation, with the banking sector having an average Basel III Liquidity Coverage Ratio (LCR) level at 143.6 percent in excess of the minimum statutory requirement of 100 percent. Meanwhile, the gross impairment ratio remained stable at 1.6 percent (2018: 1.5 percent), reflecting the banking system's sound asset quality. The overall debt servicing capacity of households and businesses remained steady, supported by healthy financial positions.

In Q3 2019, net financing expanded at a more moderate pace on lower growth of bank loans and corporate bonds. In the banking system, outstanding business loan growth moderated to 1.6 percent in Q3 2019 , down from 2.7 percent in the previous quarter. The moderation reflected the decline in loan growth to the real estate sector amid continued weakness in the property sector. The growth of outstanding corporate bonds declined to 9.0 percent during the quarter (Q2 2019: 10.6 percent), with most issuances in the finance, insurance, real estate and business services sectors. Overall, net financing expanded at a more moderate pace of 4.8 percent (Q2 2019: 5.6 percent) (see Figure 20). In

\section{FIGURE 21 \\ Household debt increased marginally to $\mathbf{8 2 . 2}$ percent of GDP}

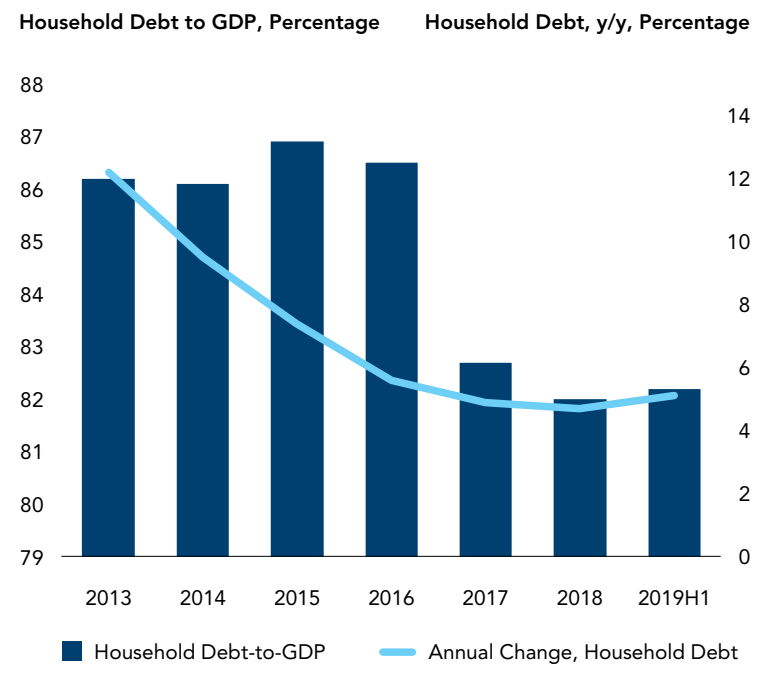




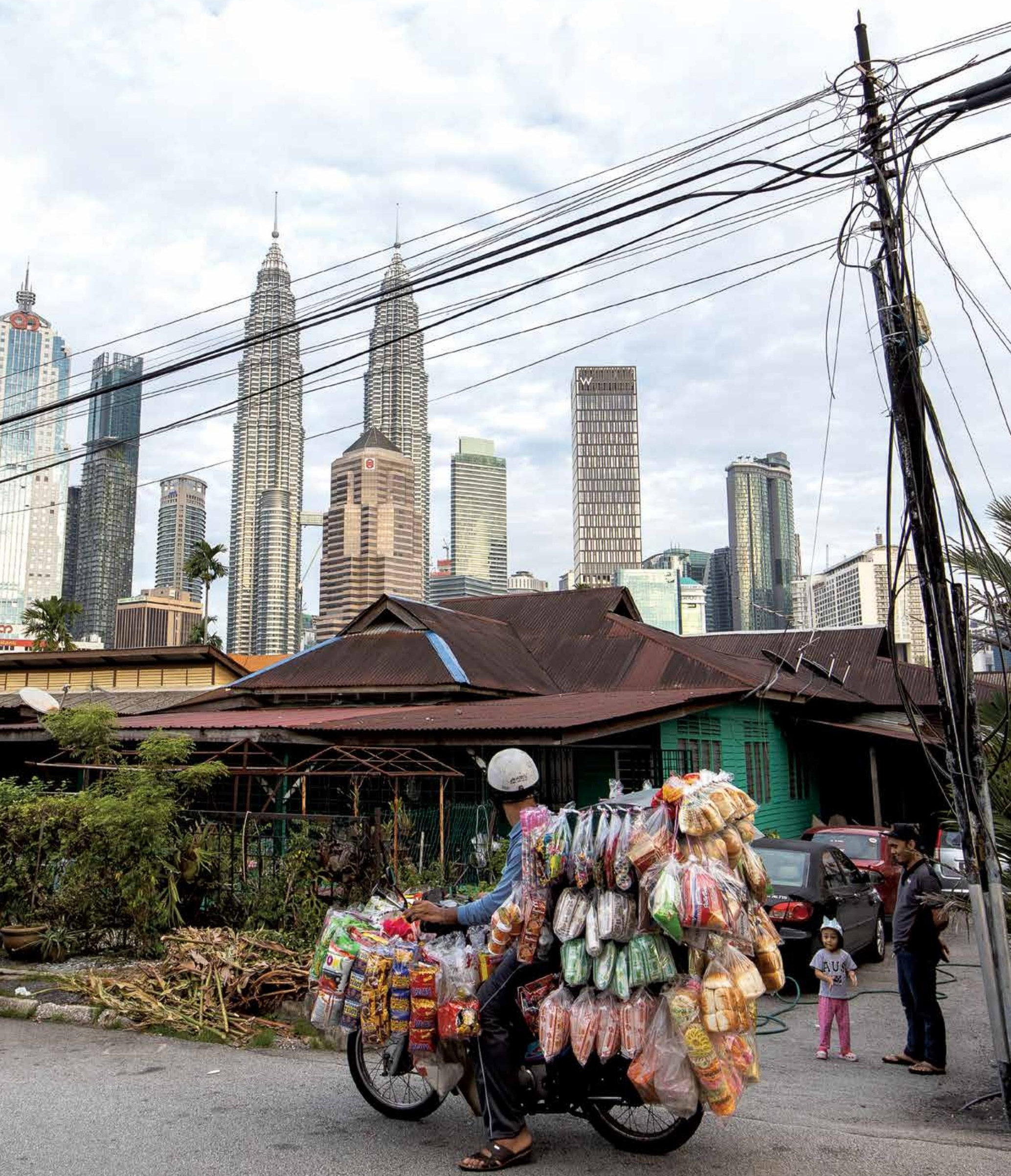


the household segment, outstanding loans expanded by 4.6 percent (Q2 2019: 4.8 percent) with an increase in loans disbursed for the purchase of residential property and personal use.

The overall household debt level increased slightly to 82.4 percent of GDP as at end-September 2019 (end-June 20219: 82.2 percent) (see Figure 21). The annual growth of household debt increased to 5.1 percent in the first half of 2019, with loans for the purchase of residential properties continuing to be the key driver of debt growth. Growth in household loans for consumption has remained modest, mainly driven by personal financing extended to civil servants by development financial institutions (DFIs). Although most households continue to be able to comfortably service their debt, there are indications of increasing risk in some areas. In particular, a higher incidence of default has been observed among housing borrowers who are more exposed to income variability. While the share of household debt held by borrowers in the lower-income segment (those who earn less than RM3,000 per month) has continued to decline over the years, the leverage of these borrowers has increased steadily, largely due to increased accessibility to housing loans with the introduction of a number of

FIGURE 22

Non-resident inflows contributed to the decline of the government bond yields...

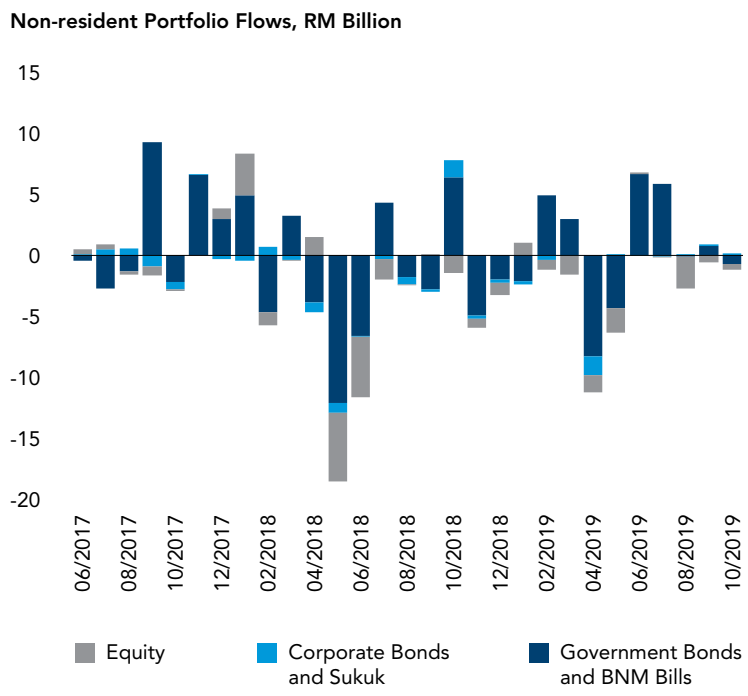

loan assistance schemes in recent years. However, risks to financial stability have remained largely contained, given banks' low level of exposure to higher-risk borrowers, with banks continuing to implement sound lending practices.

The recent performance of the domestic financial markets has been mixed (see Figure 22). The FBM $\mathrm{KLCl}$ declined by 5.3 percent, from 1672 points at the end of June to 1584 points at the end of September. This decline was in line with the recent trend in regional equity markets. In the domestic bond market, non-resident inflows contributed to the decline of Malaysian Government Securities (MGS) yields. The 3-year, 5-year and 10-year bonds decreased by 19.3, 19.7 and 29.5 basis points between the end of June and the end of September, respectively. The decision was made for Malaysia to remain in the FTSE World Government Bond Index, which led to an improvement in financial market sentiment at the end of Q3 2019. The interbank lending rates have remained broadly unchanged. During the third quarter, the ringgit depreciated against the US dollar by 1.1 percent, in line with most regional currencies except the Thai baht (see Figure 23).

\section{FIGURE 23}

...while the ringgit continued to depreciate against the US dollar

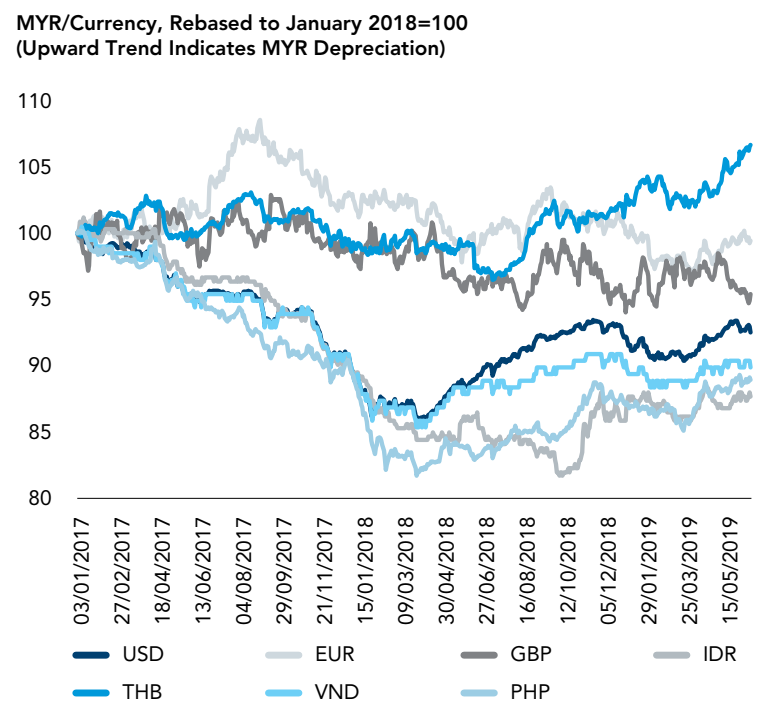

Source: World Bank staff calculations based on BNM data 


\section{Government is expected to remain on a path of fiscal consolidation}

The government is expected to meet its fiscal deficit target in 2019. The federal government's fiscal deficit is estimated to stand at 3.4 percent of GDP (2018: 3.7 percent), in line with the target established in Budget 2019 (see Figure 24). Total government revenue is expected to reach 17.4 percent of GDP (2018: 16.1 percent), slightly higher than the initial estimate of 17.1 percent. The higher-than-expected revenue collection is mainly attributable to an increase in estimated collections from sales and services tax (SST), the value of which is expected to reach RM26.8 billion, surpassing the initial estimate of RM22 billion. However, higherthan-expected revenues are expected to be offset by overspending in the area of operating expenditures $(\mathrm{OE})$, which are expected to reach 17.3 percent of GDP (2018: 16.0 percent), surpassing the initial estimate of 17.0 percent of GDP. The increase in the government's $\mathrm{OE}$ is partially due to higher-than-forecast expenditure on fuel subsidies due to the delay in the implementation of the targeted fuel subsidy program, Program Subsidi Petrol (PSP). Meanwhile, development expenditure (DE) is revised down marginally, from the initial estimate of 3.6 percent of GDP to 3.5 percent (2018: 3.9 percent), following the revision and re-timing of a number of infrastructure projects.

\section{FIGURE 24}

The federal government is expected to meet its fiscal deficit target in 2019

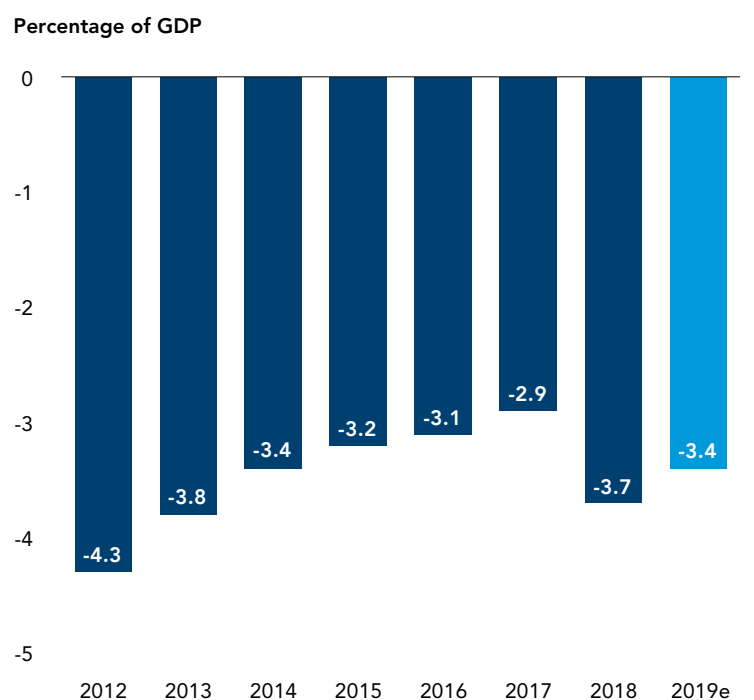

In 2019, higher-than-anticipated revenue from the SST is expected to contribute to higher federal government revenue collection (see Figure 25). This is largely driven by a better-than-expected collection in H1 2019 due to demand for four-wheel drive and sports utility vehicles, which led to increased sales tax revenues. At the same time, the increased demand for food and beverages also supported sales tax performance for the year. Overall, indirect tax constitutes about 24.6 percent of total tax revenue (2018: 25.3 percent). In the direct tax segment, individual and corporate income tax collection was also higher, due to measures implemented under the Special Voluntary Disclosure Program (SVDP), which resulted in about 270,000 participants disclosing previously undeclared income. This contributed to an additional collection of RM6 billion. In addition, stable growth in wages and corporate earnings also contributed to strong performance in the collection of individual and corporate income taxes. With lower average global oil prices, the collection of petroleum income tax is forecast to decline by 10.9 percent in 2019. Meanwhile, it is estimated that non-tax revenue will increase in 2019, following an increase in the value of dividends from PETRONAS, amounting to RM54 billion, of which RM30

\section{FIGURE 25}

Revenue is slightly higher than initially projected due to an increase in estimated SST collections

Percentage of GDP, $2019 f$

20

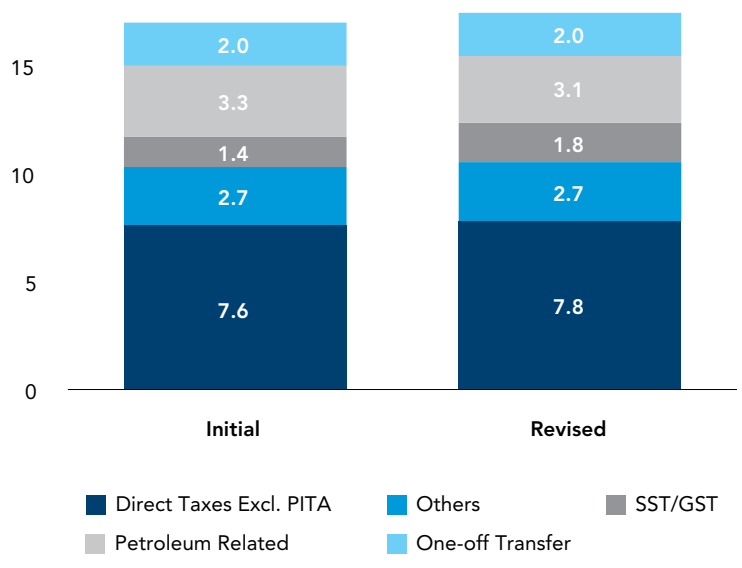

Source: MOF 
billion is a one-off special dividend. Excluding the oneoff special dividend, the share of petroleum-related revenue as a percentage of total government revenue is expected to decline slightly, from 23.3 percent in 2018 to 21.7 percent in 2019.

\section{The higher-than-expected revenue collection is mainly attributable to an increase in collections from SST.}

Estimates for the federal government's OE for 2019 have been revised upwards to reflect additional requirements for existing programs. This upward revision was largely due to the rescheduling of the implementation of the government's targeted fuel subsidy program (PSP). The petrol price has been maintained at RM2.08 per liter for RON95 since March 2019, with this price remaining in effect until the end of the year, after which the PSP framework will be implemented in January 2020. Additional allocations have also been provided for expenditure in education and health, particularly for food assistance in boarding schools, school cleaning services, and medical supplies. Spending on other social assistance programs, particularly the cash transfer program,

\section{FIGURE 26}

Federal government debt was higher at $\mathbf{5 2 . 7}$ percent of GDP in $Q 2$ 2019...

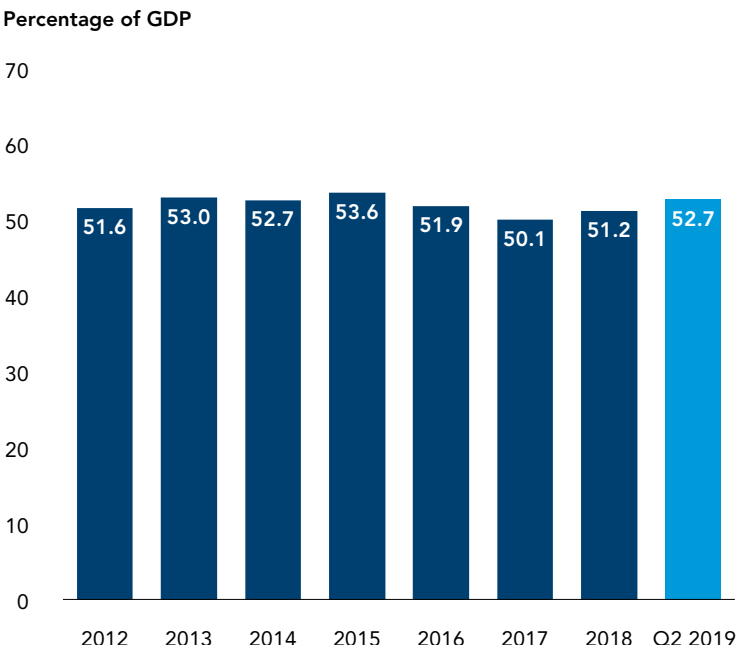

Bantuan Sara Hidup (BSH), is estimated to be lower following the restructuring of the criteria for recipients and revisions to the value of assistance that became effective in 2019. The increased OE in 2019 was also due to a one-off allocation for outstanding tax refunds. The government's wage bill continues to constitute the largest share of $O E$, with this forecast to increase to 48.2 percent ${ }^{3}$ in 2019 (2018: 45.5 percent) due to salary and pension increments. In addition, debt service charges are also estimated to increase further to 14.1 percent of federal government revenue in 2019, slightly below the government's self-imposed limit of 15 percent of revenue.

The government's DE for 2019 is forecast to be lower than the original estimate due to the revision and re-timing of several projects. The economic sector continues to take up the largest share of $D E$, with the share of this sector amounting to RM28.8 billion, or 53.7 percent of the total. Expenditures in the economic sector are mostly allocated to developing public transportation infrastructure and improving public utilities. This includes a number of key infrastructure projects, including the construction of MRT2 and the Pan Borneo Highway, and the upgrading of the Klang Valley Double Track project. The DE allocation for the social sector is estimated to account for 28 percent of the total, mostly allocated to constructing new schools, upgrading existing schools and tertiary institutions, and expanding teaching hospitals. Overall, at 3.5 percent of

\section{FIGURE 27}

...while committed guarantees increased to 10.4 percent of GDP

\section{Percentage of GDP}

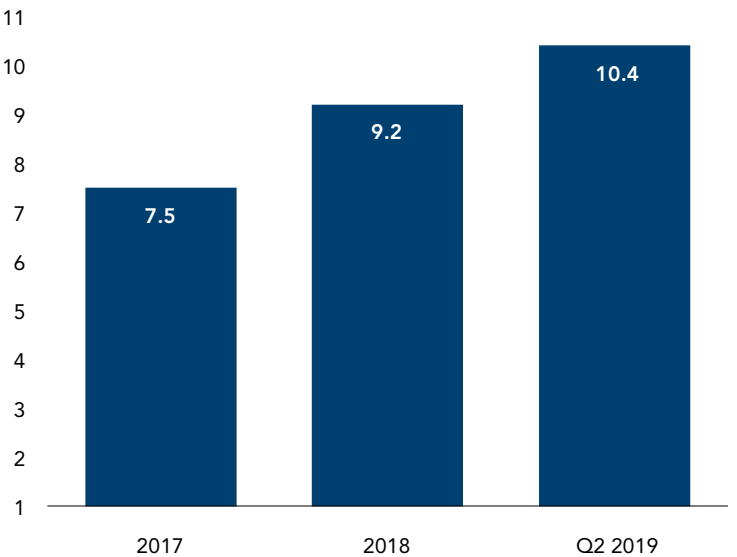

${ }^{3}$ OE excludes the one-off payment of outstanding tax refunds in 2019. 
GDP, DE in 2019 was low compared to the average level in the period from 2008 to 2016, which stood at 4.6 percent of GDP.

Federal government debt in proportion to GDP increased to 52.7 percent in Q2 2019 (2018: 51.2 percent), with risks remaining manageable (see Figure 26). Ringgit-denominated securities constitute 96.3 percent of federal government debt (2018: 97.1 percent), limiting the exposure to currency risk. Rollover risk is also limited, with the debt structure continuing to skew towards longer-tenured issuances. The average period of maturity is projected to increase from 7.6 years in 2018 to 8.1 years in 2019, following the increased issuance of debt securities with tenures of seven years or more, with a declining share of Treasury bills. As of Q2 2019, large domestic institutional investors with longer-term investment horizons remained the largest holders of government debt, accounting for 66.8 percent of total outstanding debt (2018: 66.7 percent). These domestic investors include long-term investors such as provident and retirement funds, insurance companies and financial institutions. The proportion of non-resident holdings of government debt remained relatively stable, at 22.1 percent (2018: 22.7 percent) of total outstanding debt.

\section{A gradual process of fiscal consolidation and debt reduction may be needed to preserve fiscal buffers.}

The total value of federal government debt and liabilities ${ }^{4}$ was higher at 77.1 percent of GDP in Q2 2019 (2018: 75.4 percent). The increase compared to 2018 was mainly due to an increase in committed guarantees, with their value increasing from 9.2 percent of GDP in 2018 to 10.4 percent as of Q2 20195 (see Figure 27). The government classifies entities as committed guarantees when they receive government allocations or the probability of them requiring financial assistance from the government is high. This could include assistance in the form of working capital and/or partial subsidies for their operations. Other liabilities include those related to public-private partnerships (PPP), private finance initiatives (PFI), and Pembinaan BLT Sdn. Bhd., which was set up to undertake the construction of the Royal Malaysia Police training and living facilities. These declined slightly to 12.0 percent of GDP as of Q2 2019 (2018: 12.8 percent), with no inclusions of additional financing obligations. Meanwhile, debt guaranteed by the government (GGs) declined slightly to 18 percent of GDP as of Q2 2019 (2018: 18.4 percent). Governmentguaranteed disbursements were mainly used to finance public infrastructure projects, including the MRT and the Pan Borneo Highway, and for civil servant housing loans. The average maturity period for GGs is seven years, with minimal currency risks given that more than 90 percent of $\mathrm{GGs}$ are denominated in ringgit.

During the year, the government has implemented a number of steps to enhance its debt management processes and their orderly implementation. First, in May 2019, the government announced the establishment of the debt management office (DMO), which is responsible for monitoring and reviewing potential risks that may arise from federal government debt, GGs, and other liabilities. Second, the bipartisan Special Select Committee on Budget, which was formed as part of the government's efforts to improve the quality of parliamentary institutions and to ensure the appropriate implementation of checks and balances, produced a report in July 2019 that recommended a number of measures to strengthen debt management and to enhance transparency. The report contains a number of recommendations related to GGs, including setting a statutory or administrative limit on GGs, and reviewing and assessing the list of GGs to determine the guarantees that would require assistance. Separately, an assessment conducted using the IMF's debt sustainability analysis methodology shows that under a baseline scenario, Malaysia's debt remains sustainable (IMF 2019a). However, the assessment also indicates there is a significant risk related to external financing needs arising from shocks to selected indicators such as real GDP growth, contingent liabilities and combined macro-fiscal shocks. As such, a gradual process of fiscal consolidation and debt reduction may be needed to preserve fiscal buffers against a potential economic and financial crisis.

${ }^{4}$ These comprise federal government debt, committed guarantees, 1MDB debt and other liabilities (PPP, PFI and PBLT).

${ }^{5}$ Due to an additional commitment of RM20 billion under Urusharta Jamaah Sdn. Bhd. 


\section{Fiscal policy in 2020 balances the need to preserve fiscal sustainability and support economic growth}

\begin{abstract}
Malaysia's Budget 2020 represents a prudent balance between the competing needs of preserving fiscal sustainability while also effectively responding to deteriorating external conditions. The government's fiscal consolidation initiative will continue in 2020, albeit with a revised fiscal deficit target of 3.2 percent of GDP, from the original target of 3.0 percent. The revision has been driven by the government's decision to provide pre-emptive support to sustain growth in the context of a less benign external environment. An additional allocation of 0.2 percent of GDP will be channeled to DE to revitalize public investment through infrastructure projects including the MRT2 and the Pan Borneo Highway projects. Over a longer-term horizon, the government's medium-term fiscal framework (MTFF) for 2020-2022 are based on assumptions of real GDP growth rates of 4.5 to 5 percent (2020f: 4.8 percent) and of crude oil prices at between US\$60-65 per barrel. The MTFF also projects revenue collections to stand at 15 percent of GDP; total expenditure at 17.8 percent of GDP; and the
\end{abstract}

FIGURE 28

The civil service wage bill will continue to dominate operational expenditures

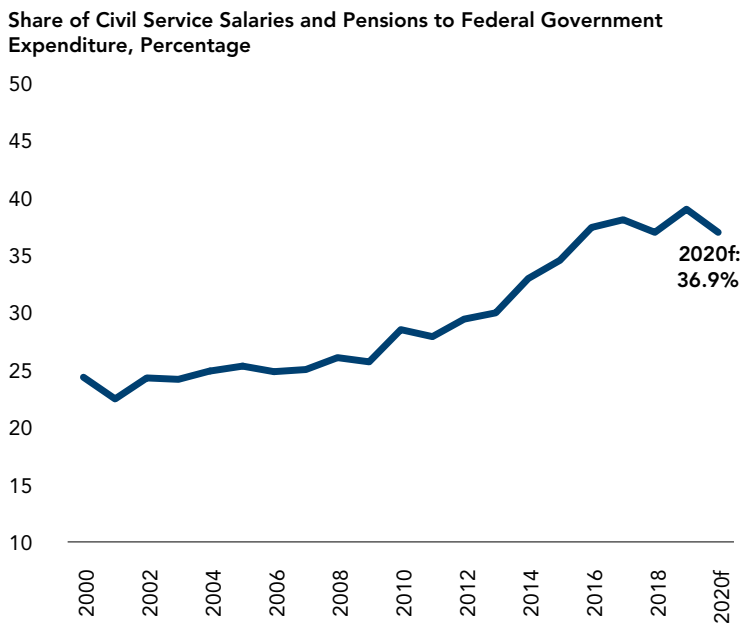

fiscal deficit at 2.8 percent of GDP on average for the three-year period.

Total government expenditure is expected to increase slightly to 18.4 percent of GDP in 2020 (2019e: 18.4 percent). The civil service wage bill, which is expected to account for 36.9 percent of total government expenditure (2019e: 38.9 percent), continues to dominate OE (see Figure 28). The government is currently exploring options to develop a more robust scheme to efficiently manage its pension obligations. Expenditure on subsidies and social services, most of which is allocated to BSH and other welfare assistance programs, fuel and agriculture subsidies, and toll compensation, is expected to decrease slightly to 8.1 percent of total government expenditure (2019e: 8.4 percent). The decline is partly due to the implementation of PSP, which is projected to result in a reduction to fuel subsidies. In addition, the amount allocated for BSH in 2020 is expected to be maintained at RM5 billion. In terms of DE, the

\section{FIGURE 29}

Government revenue is expected to decline further next year

General Government Revenue ${ }^{6}$, Percentage of GDP

30

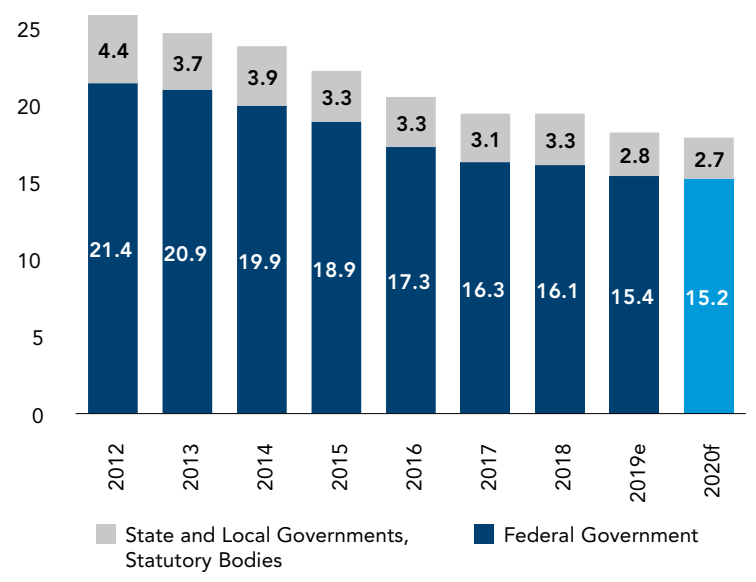

Source: MOF 
economic sector, which includes the transport, energy and public utilities subsectors, will continue to receive the largest share, to support the achievement of the government's goal of enhancing economic productivity and competitiveness. This includes the construction of key infrastructure projects, the upgrading of schools, and improving broadband infrastructure, especially in suburban and rural areas. At an aggregate level, the top three recipients of government expenditure are the Ministry of Education, the Ministry of Health, and the Ministry of Finance.

\section{While the recently announced revenue-enhancing measures contained in Budget 2020 are a step in the right direction, further efforts are required to boost public} sector revenues.

Federal government revenue is expected to decline further in 2020 to 15.2 percent of GDP (2019e: 15.4 percent $^{6}$ ) (see Figure 29). Tax revenue, which accounts for the greatest share of total government revenue, is expected to remain stable at 11.8 percent of GDP (2019e: 11.9 percent). Of this tax revenue, the largest proportion will be derived from direct tax (75.1 percent of total tax revenue). Corporate and personal income tax are expected to remain relatively stable, at 4.7 percent and 2.3 percent of GDP respectively. Indirect tax collection is also expected to remain constant, at 2.9 percent of GDP. Proceeds from the SST, which contribute the largest share of indirect tax, are expected to stand at 1.8 percent of GDP (2019e: 1.8 percent), driven by resilient household spending, increased tourists' arrivals and by a number of large international events taking place next year. Petroleumrelated revenue is expected to decline to 3.1 percent of GDP in 2020 (2019e: 3.3 percent) due to projected lower crude oil prices.

From a longer-term perspective, the expected decrease in federal government revenue in $\mathbf{2 0 2 0}$ represents a continuation of a downward trend that commenced in 2012. Federal government revenue is estimated to reach 15.2 percent of GDP in 2020, significantly lower than most international comparators, with the average for upper-middle income countries standing at 28 percent. The continuing decline in government revenue, combined with increased locked-in expenditures such as the civil servants wage bill, will increasingly limits the effectiveness of fiscal policy to counter economic fluctuations, to facilitate redistribution, and to sustain the provision of vital public services. While the recently announced revenueenhancing measures contained in Budget 2020 are a step in the right direction, further efforts are required to boost public sector revenues (see Box 4 for lessons from other countries in communicating fiscal policy reforms).

In Budget 2020, the government has announced a number of measures to enable it to diversify its revenue base and to achieve greater progressivity in its tax framework. This includes a proposal for a new income tax band for taxable income in excess of RM2 million, to be taxed at 30 per cent, which is a 2-percentage point increase from the current rate of 28 per cent. The proposed increase would affect approximately 2,000 top income earners in the country. The government also announced the extension of SST to cover imported digital services effective January 2020. In addition, the government indicated that it will consider implementing measures proposed by the tax reform committee (TRC) to widen the tax gap, which has been narrowed as the result of the implementation of various tax incentives. These measures include a review of existing tax incentives, with an exploration of legislation to reduce tax leakages and to identify new sources of sustainable tax revenue, including possible digital and environmental taxes. 
TABLE 3

Federal Government financial position

\begin{tabular}{|c|c|c|c|c|c|c|c|c|}
\hline & \multicolumn{4}{|c|}{ RM billion } & \multicolumn{4}{|c|}{ Percentage of GDP (current prices) } \\
\hline & 2017 & 2018 & $2019 e$ & $2020 f$ & 2017 & 2018 & $2019 e$ & $2020 f$ \\
\hline Revenue & 220.4 & 232.9 & 263.3 & 244.5 & 16.3 & 16.1 & 17.4 & 15.2 \\
\hline Direct Taxes & 116.0 & 130.0 & 135.6 & 142.7 & 8.6 & 9.0 & 8.9 & 8.9 \\
\hline Companies Income Tax & 64.5 & 66.5 & 70.8 & 75.5 & 4.8 & 4.6 & 4.7 & 4.7 \\
\hline Petroleum Income Tax & 11.8 & 20.1 & 17.9 & 17.5 & 0.9 & 1.4 & 1.2 & 1.1 \\
\hline Individual income tax & 28.9 & 32.6 & 35.2 & 37.4 & 2.1 & 2.3 & 2.3 & 2.3 \\
\hline Others & 10.9 & 10.9 & 11.8 & 12.4 & 0.8 & 0.8 & 0.8 & 0.8 \\
\hline Indirect Taxes & 61.6 & 44.0 & 44.4 & 47.3 & 4.6 & 3.0 & 2.9 & 2.9 \\
\hline Sales and Service Tax & 44.4 & 25.7 & 26.8 & 28.3 & 3.3 & 1.8 & 1.8 & 1.8 \\
\hline Excise Duties & 10.1 & 10.8 & 10.5 & 11.0 & 0.7 & 0.7 & 0.7 & 0.7 \\
\hline Others & 7.2 & 7.6 & 7.1 & 8.0 & 0.5 & 0.5 & 0.5 & 0.5 \\
\hline Non-Tax Revenue & 42.7 & 58.8 & 83.3 & 54.6 & 3.1 & 4.1 & 5.5 & 3.4 \\
\hline Operating Expenditure & 217.7 & 231.0 & 262.3 & 241.0 & 16.1 & 16.0 & 17.3 & 15.0 \\
\hline Emoluments & 77.0 & 80.0 & 82.0 & 82.6 & 5.7 & 5.5 & 5.4 & 5.1 \\
\hline Retirement Charges & 22.8 & 25.2 & 26.6 & 27.1 & 1.7 & 1.7 & 1.8 & 1.7 \\
\hline Debt Service Charges & 27.9 & 30.5 & 33.0 & 34.9 & 2.1 & 2.1 & 2.2 & 2.2 \\
\hline Supplies and Services & 34.7 & 35.3 & 30.2 & 38.5 & 2.6 & 2.4 & 2.0 & 2.4 \\
\hline Subsidies & 22.4 & 27.5 & 23.6 & 24.2 & 1.7 & 1.9 & 1.6 & 1.5 \\
\hline Others & 32.9 & 32.4 & 66.9 & 33.7 & 2.4 & 2.2 & 4.4 & 2.1 \\
\hline Gross Development Expenditure & 44.9 & 56.1 & 53.7 & 56.0 & 3.3 & 3.9 & 3.5 & 3.5 \\
\hline Economic Services & 24.2 & 36.1 & 28.8 & 31.0 & 1.8 & 2.5 & 1.9 & 1.9 \\
\hline Defense and Security & 5.3 & 4.9 & 6.7 & 6.6 & 0.4 & 0.3 & 0.4 & 0.4 \\
\hline Social Services & 12.4 & 12.9 & 15.0 & 15.1 & 0.9 & 0.9 & 1.0 & 0.9 \\
\hline General Administration & 2.9 & 2.2 & 3.2 & 3.4 & 0.2 & 0.2 & 0.2 & 0.2 \\
\hline Less: Loan Recoveries & 1.9 & 0.8 & 0.9 & 0.8 & 0.1 & 0.1 & 0.1 & 0.0 \\
\hline Net Development Expenditure & 43.0 & 55.3 & 52.8 & 55.2 & 3.2 & 3.8 & 3.5 & 3.4 \\
\hline Overall Surplus / Deficits (-) & -40.3 & -53.4 & -51.8 & -51.7 & -2.9 & -3.7 & -3.4 & -3.2 \\
\hline
\end{tabular}

Source: World Bank staff calculations based on MOF data 


\section{Policy reforms are more likely to succeed when they are communicated effectively}

Public policies are not created and adapted in a vacuum. Some are created out of demand while others are delivered out of necessity even if they don't enjoy public support. Tough reforms are necessary to realize long-term gains, but gaining public support and effective implementation require clear, concerted and careful stakeholder management. This is where communications can be a useful tool to facilitate a country's reform efforts.

The strategic and deliberate use of communications can help build public trust and confidence in institutions, which is vital to ensure policy success. When the public trusts state institutions, the state has reservoirs of political capital on which it can draw on to propose and explain difficult reforms that may result in long-term gains, but at the cost of some short-term difficulties, at least for some key stakeholder groups.
Establishing an effective communication system is important for the effective design, promulgation and implementation of policy. A good example of a government developing an effective communication system as a policy tool is in the United Kingdom, where the Government Communications Service (GCS) operates across the civil service to deliver communications and socialize policies. GCS brings together more than 4,000 professionals across 25 ministerial departments, 20 non-ministerial departments and more than 400 agencies and public bodies. It recently published its inaugural Communication Plan for 2018/2019, which coordinates the delivery of 140 integrated communication campaigns nationwide.

Government communications units need to engage with many different audiences with varying levels of involvement suited for specific periods in the reform process. A recent paper by the IMF, entitled

\section{FIGURE 30}

A timeline for communicating policy changes

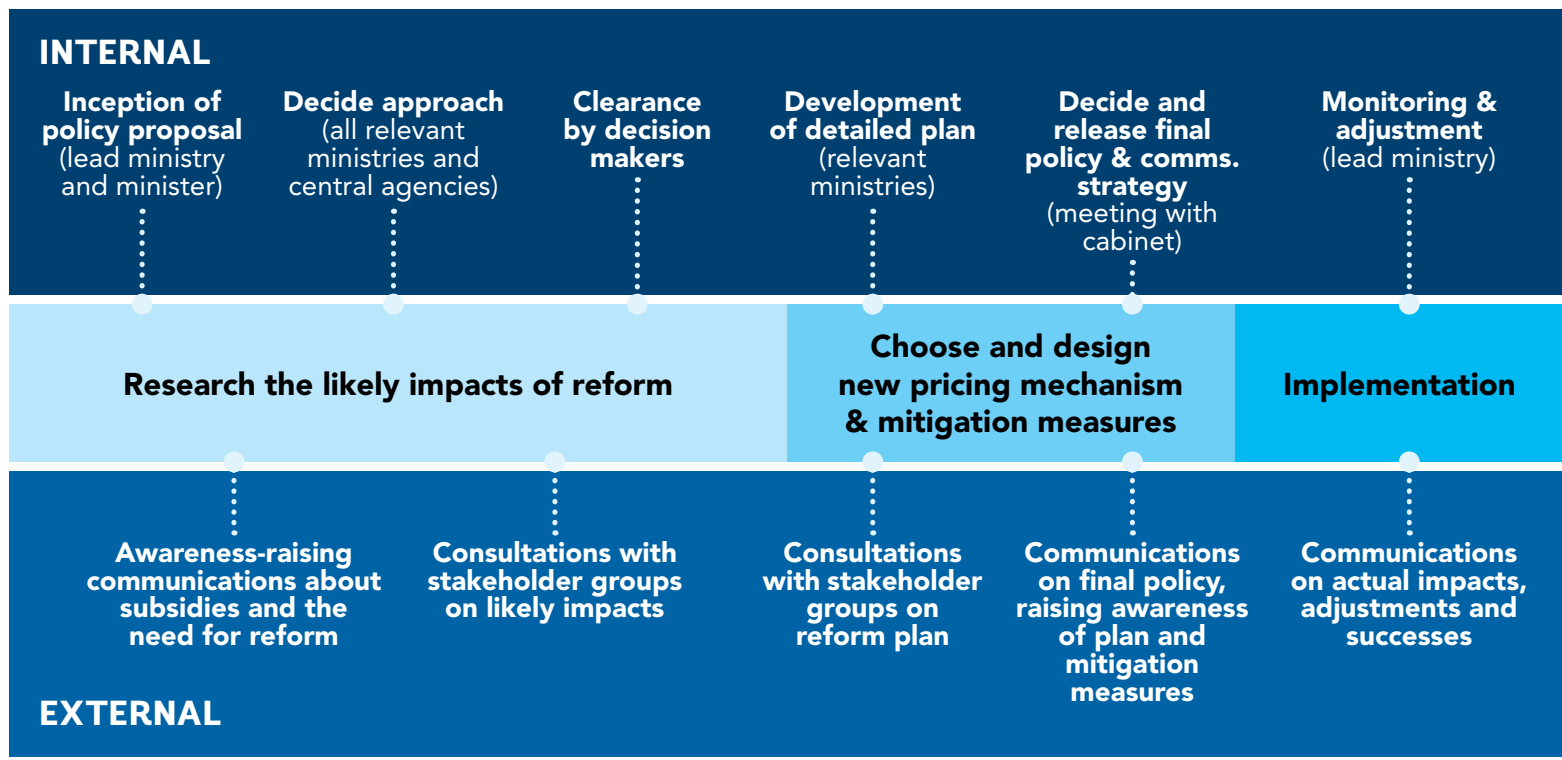

Source: IISD (2013) - Guidebook to Fuel Subsidy Reform for Policy Makers in Southeast Asia. 
Frontiers of Economic Policy Communications, states that in order to be more effective and strategic, "communications need to be increasingly integrated with operations, drawing on an in-depth understanding of policies and their future path."

Listening to stakeholders, acknowledging their concerns, and responding to them with action is a core part of the policymaking process. Ultimately, citizens are the principal beneficiaries of reforms. Thus, being attentive to their voices is vital not only to ensure buy-in, but also as a source of input and feedback on the actual design and substance of the policy proposals. In this area, the Porto Alegre municipality in Brazil was a forerunner when it pioneered participatory budgeting in the 1990s. Since then, this model has been emulated around the world, with more than 2,700 governments implementing some version of it today.

Institutionalizing public participation sends a signal to stakeholders that they are formally involved in the development and policy process. It encourages citizens to engage directly and actively through formal platforms. These channels may include a range of mechanisms to facilitate dialogue such as public consultations, roundtable discussions, town hall meetings, as well as digital means such as social media.

\section{Staying connected and being engaged is key} to effective policy making. Continued dialogue with stakeholders throughout the formulation and implementation of policy can increase public understanding of the expected policy-trade offs while building public support and trust in institutions along the way (see Figure 30). Without effective communication, it may not be possible to implement essential but difficult reforms, and attempts to do so can lead to undesired political implications.

An example of effective communication is the recent natural gas pricing reform in Ukraine. Faced with the need to reform price subsidies for natural gas, the government engaged conducted public opinion research and focus groups across the country. Citizen feedback was used to design compelling messages for an awareness-raising campaign, improve consumer knowledge, facilitate public debate, and shape public opinion about the importance of reforms. The campaign was launched with evidence-based messaging about the need to reform gas price subsidies, efforts to mitigate the impacts of price increases especially for poor households, and improvements to national social assistance programs. The impact of these efforts was far-reaching: enrollment in assistance programs increased significantly from around 1 million low-income households in 2014 to 6.5 million in 2017, many adopted energy efficiency measures, and the government committed to continuing the reform process.

\section{Gaining public support for reforms requires clear, concerted and careful stakeholder management.}

In Jamaica, the government implemented a communications strategy to support the transition to full-fledged inflation targeting over the medium term. Prior to the implementation of the measure, the Bank of Jamaica strengthened its communications capacity and conducted public relations campaigns to explain to the public the benefits of price stability - contributing significantly to the credibility of the policy transition. In particular, the authorities used radio advertising and billboards to convey powerful messages through formats inspired by Jamaica's popular culture, including reggae music.

Fundamentally, effective communications campaigns enable policymakers to stay engaged with stakeholder groups and the broader public throughout the policy process. The two examples above demonstrate that engagement with the public prior to and during the implementation of complex and sometimes unpopular reforms is essential, particularly when policies result in significant pushback from vested interests.

Citizens around the world are increasingly connected, with information more easily shared and disseminated. This has increased the demand for government transparency in all areas, including on economic policy decisions. It has elevated the role of public discourse and public opinion in policymaking, giving citizens greater voice in their own governance. Policymakers should consider communications as a policy tool that can be used effectively to increase the odds of success for the reforms they propose. 


\section{Economic outlook}

\section{Growth in developing EAP is projected to decelerate over the forecast horizon}

Global growth is expected to remain subdued over the near term, before improving moderately over a longer forecast horizon. Global growth is projected to expand at 2.5 percent in 2020, 0.2 percentage points lower than projected in June, reflecting broadbased weakness in advanced economies and major EMDEs (see Figure 31). Global economic conditions are expected to improve marginally over a longer forecast horizon, with the global growth rate projected to increase to 2.6 percent in 2021 and to 2.7 percent in 2022. After slowing to 1.4 percent in 2020 , growth in advanced economies is projected to improve slightly to 1.5 percent in both 2021 and 2022. Growth in EMDEs is expected to recover over the next two years. This projection is predicated on a rebound in several large EMDEs, some of which are emerging from deep recessions or sharp slowdowns but remain fragile.

Growth projections for the developing EAP have

FIGURE 31

Global economic growth is expected to remain subdued over the near term

GDP, y/y, Percentage

6

5

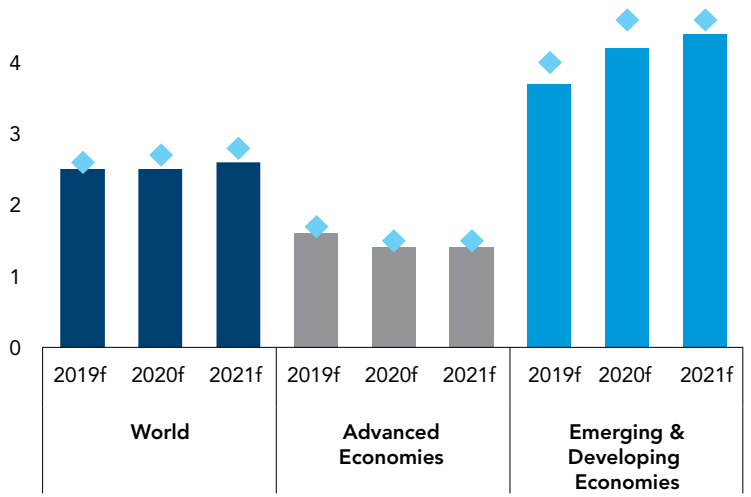

Source: World Bank staff projections been revised down due to increased headwinds. Regional growth is expected to decelerate to 5.7 percent in 2020, 0.2 percentage points lower than previously projected, with the downside risks related to global demand and trade materializing or intensifying (see Figure 32). In China, growth is projected to ease to 5.9 percent in 2020, and continue to decline to 5.8 percent in 2021, reflecting the increasing impact of structural constraints such as a shrinking labor force and subdued productivity growth. Growth in other major economies in the region will also decelerate in 2019, although recovery may be expected in following years in some of these economies, reflecting country-specific conditions. Private consumption is expected to remain the primary driver of growth, partially offsetting the negative effects of moderating investment and trade activity in the context of a less supportive external environment.

\section{FIGURE 32}

Growth in developing EAP has been revised down amid increased headwinds

\section{GDP, y/y, Percentage}

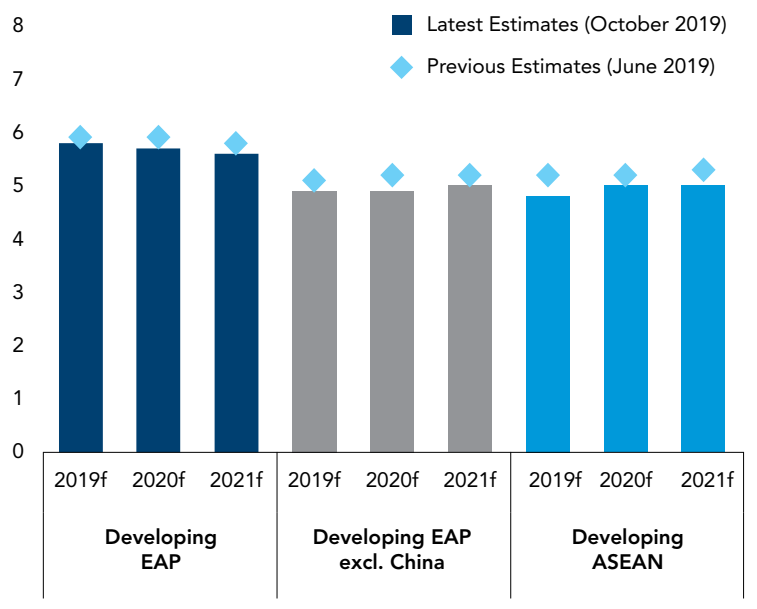

Source: World Bank staff projections 


\section{Malaysia's economy will continue to grow at a relatively moderate pace}

\begin{abstract}
Malaysia's economy is projected to grow at a relatively moderate pace over the near term, with increased headwinds. In 2020, the forecast for Malaysia's GDP growth rate is revised down slightly to 4.5 percent (2019f: 4.6 percent), largely due to weakerthan-anticipated investment and export growth in Q3 2019 (see Table 4). Private consumption is projected to expand at a lower but still robust rate of 6.5 percent next year (2019f: 7.2 percent), with growth driven by stable labor market conditions, relatively benign inflation, and continued support from government measures. In the public sector, the planned rationalization of government operating expenditure will continue to weigh on the contribution from government consumption, which is projected to grow at the rate of 1.9 percent in 2020 (2019f: 2.1 percent).
\end{abstract}

Gross fixed capital formation is expected to improve but remain subdued in 2020, with both the public and private sectors continuing to adopt a cautious stance regarding capital spending. Overall investment activity is projected to expand at 1.4 percent next year (2019f: -1.8 percent), 0.3 percentage points lower than in the previous forecast. The downward revision largely reflects weaker-than-expected private investment activity in Q3 2019, with subdued trade prospects and heightened uncertainty weighing markedly on business confidence and investment intentions. Public investment is likely to continue to contract over the near term, in line with the ongoing fiscal consolidation, although the contraction may be limited by the increase in planned investments from public corporations in the transport and mining sectors. Inventory destocking begun in Q1 2018 is expected to normalize and provide modest support to growth over the forecast period.

\section{In 2020, Malaysia's GDP growth rate is forecast to be 4.5 percent.}

Export growth is likely to remain soft into next year, reflecting the continuing slowdown in global investment and trade activity. Malaysia's export growth is projected to remain modest at 0.5 percent next year (2019f: -0.3 percent), with less supportive global economic conditions and prolonged trade-related policy uncertainty. This is expected to be partially offset by a recovery in mining exports, following unforeseen

TABLE 4

GDP growth and contribution to growth

\begin{tabular}{|c|c|c|c|c|c|c|c|c|c|}
\hline \multicolumn{5}{|c|}{ Annual Growth, y/y, Percentage } & \multicolumn{5}{|c|}{ Contribution to Annual GDP Growth (Percentage Point) } \\
\hline & 2018 & $2019 f$ & $2020 f$ & $2021 f$ & & 2018 & $2019 f$ & $2020 f$ & $2021 f$ \\
\hline GDP & 4.7 & 4.6 & 4.5 & 4.5 & & & & & \\
\hline $\begin{array}{l}\text { Domestic Demand } \\
\text { (including stocks) }\end{array}$ & 4.3 & 3.9 & 4.7 & 5.0 & $\begin{array}{l}\text { Domestic Demand } \\
\text { (including stocks) }\end{array}$ & 4.0 & 3.7 & 4.3 & 4.6 \\
\hline $\begin{array}{l}\text { Private } \\
\text { Consumption }\end{array}$ & 8.0 & 7.2 & 6.5 & 6.3 & $\begin{array}{l}\text { Private } \\
\text { Consumption }\end{array}$ & 4.4 & 4.0 & 3.7 & 3.6 \\
\hline Public Consumption & 3.3 & 2.1 & 1.9 & 1.9 & Public Consumption & 0.4 & 0.3 & 0.2 & 0.2 \\
\hline \multirow[t]{2}{*}{$\begin{array}{l}\text { Gross Fixed Capital } \\
\text { Formation }\end{array}$} & 1.4 & -1.8 & 1.4 & 1.7 & $\begin{array}{l}\text { Gross Fixed Capital } \\
\text { Formation }\end{array}$ & 0.3 & -0.4 & 0.3 & 0.4 \\
\hline & & & & & Change in Stocks & -1.2 & -0.1 & 0.1 & 0.3 \\
\hline External Demand & & & & & External Demand & & & & \\
\hline $\begin{array}{l}\text { Exports of Goods \& } \\
\text { Services }\end{array}$ & 2.2 & -0.3 & 0.5 & 0.7 & $\begin{array}{l}\text { Exports of Goods \& } \\
\text { Services }\end{array}$ & 1.5 & -0.2 & 0.4 & 0.4 \\
\hline $\begin{array}{l}\text { Imports of Goods \& } \\
\text { Services }\end{array}$ & 1.3 & -1.8 & 0.4 & 0.8 & $\begin{array}{l}\text { Imports of Goods \& } \\
\text { Services }\end{array}$ & 0.8 & -1.1 & 0.2 & 0.5 \\
\hline
\end{tabular}


FIGURE 33

The sentiment-based forecast of GDP growth is converging with the consensus forecast...

GDP, 2019f, y/y, Percentage

5.0

4.5

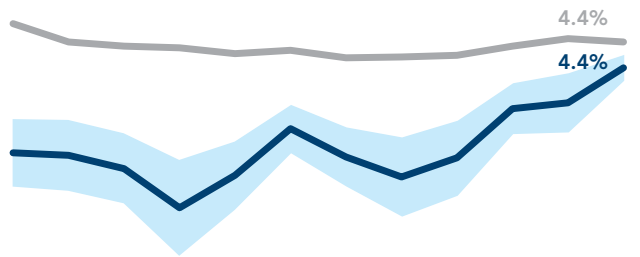

3.5

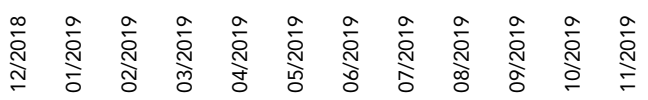

- Sentiment-adjusted Forecast $\longrightarrow$ Mean Consensus Forecast

Sentiment-adjusted Forecast Range

Source: World Bank staff projections

supply disruptions in recent quarters. Similarly, import growth is projected to increase at the modest rate of only 0.4 percent in 2020 (2019f: -1.8 percent), with the growth of intermediate and capital exports regaining some momentum and with slight improvements in export and investment activity. The current account surplus is projected to narrow to around 3.0 percent of GDP in 2020, with a more moderate trade surplus in goods continuing to offset the persistent deficits in services and income accounts.

News-based measures of economic sentiment continue to point to a slightly lower forecast for GDP growth than the consensus of professional forecasters. Complementary news-based measures of economic sentiment ${ }^{7}$ indicate a softer perception of the economic conditions in Malaysia during the course of 2019, with the sentiment-adjusted growth forecast tracking below the consensus forecast throughout the period (see Figure 33). Below-trend optimism was especially notable across trade-related news throughout the year, particularly due to the ongoing trade tensions between the US and China. The overall
FIGURE 34

...reflecting lower below-trend optimism in the economic and corporate clusters

News Sentiment, Z-score

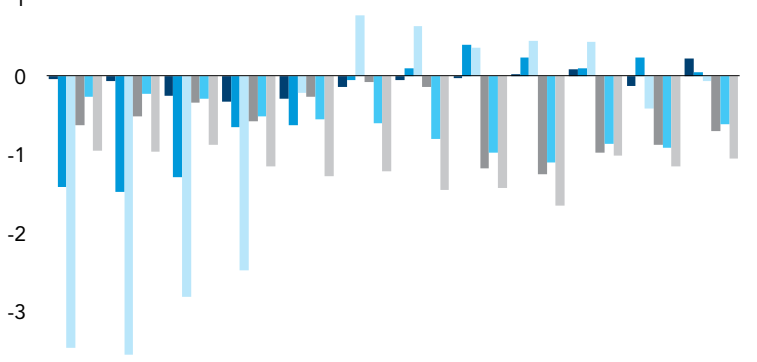

$-4$

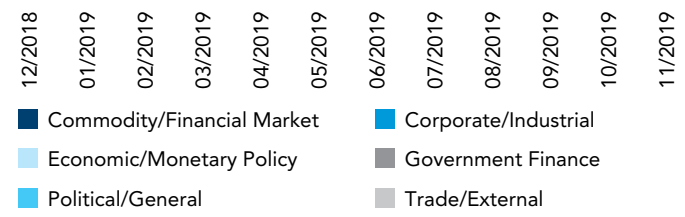

Source: World Bank staff calculations

sentiment improved during the second half of the year, supported in part by BNM's decision to lower the OPR in May (see Figure 34).

Headline inflation is projected to increase modestly in 2020, with the effects of policy-related factors dissipating. The average consumer price inflation rate is projected to increase to 1.5 - 2.0 percent next year (2019f: 0.7 percent), mainly reflecting the dissipating impact of the consumption tax policy changes implemented in 2018. Additionally, the reintroduction of the float pricing mechanism for RON95 petrol and diesel in January 2020 is expected to result in modest increases in transportation costs. Underlying inflation is expected to be broadly contained into 2020 in the absence of immediate domestic cost pressures.

\footnotetext{
7 The news-based sentiment index is derived by the staff of the World Bank through an analysis of the proportion of positive words ("gain", "improve", "agreement", etc.) relative to the proportion of negative words ("concern", "fear", "decline", etc.) present in a vast collection of news articles on Malaysia's economy. Information derived from media reports has two main advantages compared to official statistics. First, measurements of economic conditions can be calculated in real-time, at a daily frequency. Second, this information enables the measurement of economic forces that might not be easily captured by traditional data sources, providing complementary insight into factors such as the collective sentiment regarding economic prospects. A recent study based on historical data in 25 countries between 1991 and 2017 suggests that including news-based measures of sentiment reduces the forecast errors of GDP growth by 12 percent on average relative to the consensus forecast.
} 


\section{Risks to growth outlook are firmly on the downside amid challenging external conditions}

\begin{abstract}
Various downside risks to the global economy could have spillover effects on Malaysia's economy. Further escalations to the current trade tensions between the US and China could exacerbate growing uncertainty and further dampen trade activity. The impact of increased protectionism on global growth has been magnified by protracted policy uncertainty and a decline in confidence, which in turn has depressed private investment. In the near term, further disruptions to U.S.-China economic ties would result in damage not only to these two economies, but also to the rest of the world, with its effects propagating through trade, financial, and commodity linkages. Moreover, any further deepening of the slowdown in the major economies or a sharper-than-expected deceleration in China could lead to an additional deterioration in export and growth prospects. Conversely, a deescalation of U.S.-China trade tensions could result in an earlier-than-expected recovery in export growth. Other risks emanating from the global economy relate to potential swings in the commodity markets, with higher-than-expected increases to energy prices potentially leading to increasing inflationary pressures, and with an unexpected and persistent decline in commodity prices potentially affecting growth and leading to further fiscal pressures in Malaysia.
\end{abstract}

On the domestic front, downside risks to growth primarily emanate from factors related to prolonged uncertainty among investors and delayed recovery in commodity-related sectors. Investment growth has been subdued over the recent quarters, weighed down by lower capital spending. Indicators of business sentiment ${ }^{8}$ suggest the level of confidence in the economy remains low. While uncertainty regarding the global economic outlook would have an adverse impact on Malaysia's economy, similar uncertainty regarding the domestic economy and political developments could exacerbate cautious sentiment, further dampening private investment. Sustained weakness in private investment would affect Malaysia's medium-term growth prospects and depress growth in potential output. Similarly, a prolonged slowdown in the E\&E sector and unforeseen disruptions to production in the mining sector could further weigh on growth. Finally, the moderation in wage growth, particularly in the manufacturing sector, could affect private consumption.

\section{The impact of increased protectionism on global growth has been magnified by protracted policy uncertainty and a decline in confidence.}

The persistent decline in government revenue, combined with a high proportion of locked-in expenditures, will continue to constrain fiscal policy space. The government has introduced a number of new revenue measures intended to diversify its revenue base. The overall impact of these revenue measures, however, is expected to be relatively modest. Thus, the continued downward trend in the government's revenue collection as a share of GDP and its growing share of locked-in expenditures, including the wage bill and debt servicing costs, could limit the flexibility of fiscal adjustment against future macroeconomic shocks. The sizable stock of public debt, and increased committed government guarantees and other liabilities may further constrain fiscal policy space in the future. In the private sector, the relatively high level of household debt in the context of persistent property market excesses remains a source of risk to macro-financial stability, as well as a potential constraint on household spending. 


\section{Near-term policies should focus on boosting resilience and protecting the vulnerable}

\begin{abstract}
With the continuing downward trend in government revenues and with the increase in locked-in expenditures, there is a critical need for the government to diversify its revenue base and to increase its revenue collection through more progressive taxation. In the context of a more uncertain economic environment, it is vital for Malaysia to preserve fiscal space to enable it to mitigate the impact of any negative shocks to the economy. Furthermore, societal expectations regarding the provision and quality of public services and facilities are increasing over time. It will become increasingly challenging for the government to meet these expectations. General government revenue as a share of GDP is expected to decline further to 17.9 percent in 2020 (2019e: 18.2 percent $^{9}$ ), well below its regional and aspirational comparators (see Figure 35), and Malaysia significantly under-collects in key revenue areas such as personal income and consumption taxes..$^{10}$
\end{abstract}

In addition, increased locked-in expenditures, including expenditures on the wage bill and debt servicing, have constrained development and

\section{FIGURE 35}

Malaysia's revenue collection is well below its regional and aspirational comparators

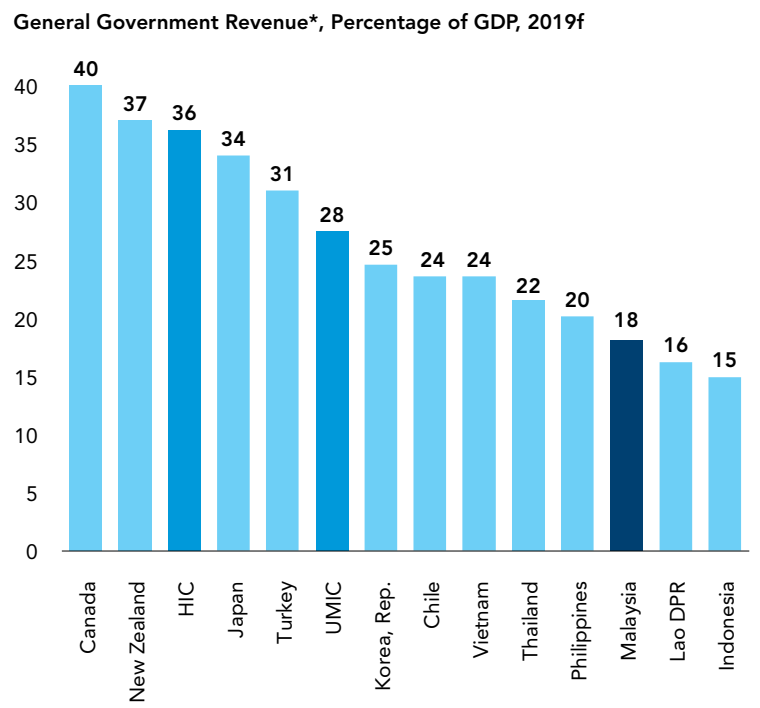

Source: World Bank staff calculations

*Excludes one-off contributions from Petronas in 2019 social spending, limiting the effectiveness of fiscal policy as a redistributive tool to facilitate the achievement of shared prosperity. Malaysia's Gini coefficient of market income (before government transfers and income tax payments) is lower than the average for OECD countries, implying a lower level of income inequality. However, through progressive taxation and social safety net systems, OECD countries are able to achieve a significant reduction in income inequality and thus a lower Gini coefficient compared to in Malaysia (see Figure 36).

Increased progressivity in the current personal income tax framework and an expansion of current tax measures could enable the government to increase revenues and to improve redistribution at the same time. The government has taken a step in the right direction with its proposal in Budget 2020 of a new income tax band for taxable income in excess of RM2 million, to be taxed at the rate of 30 percent. Nonetheless, additional steps could be taken, including measures to increase the tax bracket for the other higher income bands, and to review the tax reliefs and

\section{FIGURE 36}

Progressive taxation and social safety nets have helped OECD countries to achieve lower income inequality compared to Malaysia

Gini Coefficient 2016

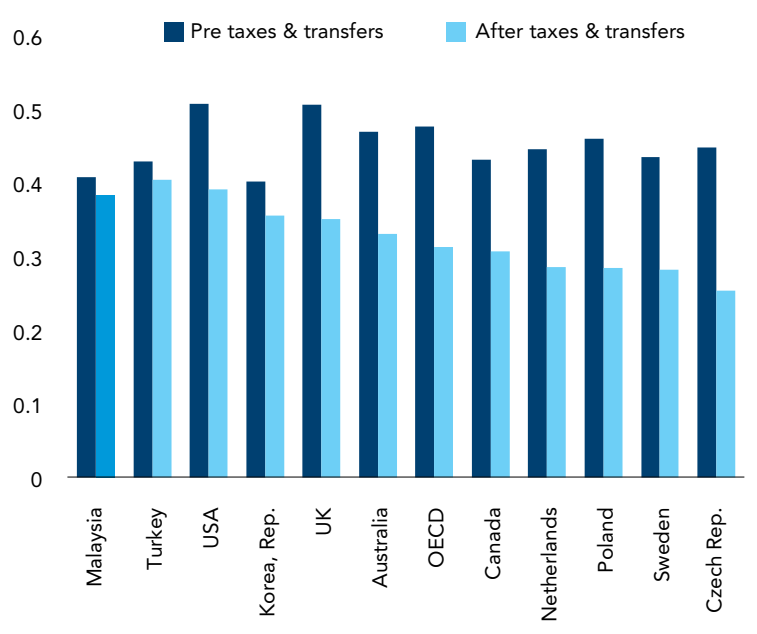

Source: World Bank staff calculations 
exemptions applied to these higher income bands. In addition, the scope of the real property gains tax (RPGT) could be widened by reducing tax relief to owners of multiple properties, and by increasing stamp duty on purchases of higher-value or multiple properties. These measures could result in significant increases to revenue while having minimal impact on lower- and middle-income households. Finally, a gradual lifting of the SST exemptions and zero-ratings on selected nonessential items, particularly those not within the B40 consumption basket, could also facilitate increased revenue without jeopardizing the purchasing power of lower-income households.

Weakening trade and investment activity amid a less favorable external environment underscores the need to increase trade diversification and improve private sector confidence. In an environment of softer global demand and increased protectionist tendencies among the major economies, a sustained commitment to deepening regional integration (through both the Comprehensive and Progressive Trans Pacific Partnership and the Regional Comprehensive Economic Partnership) and addressing the remaining trade barriers is pivotal to preserve a vibrant trading environment and send confidence-building signals to investors.

Further, it is also important to strengthen Malaysia's competitiveness in attracting quality investments and to maximize the gains from tax expenditures. This could be achieved through better targeting of investment promotion, including the focused use of incentives, towards economic upgrading, high-value job creation and inclusive growth. A crucial starting point is to revisit the overarching development objectives and strategic directions of investment policy, and prioritize efforts towards attracting investment activities that contribute most to these national aspirations. These efforts should be complemented by more effective coordination across the many investment promotion agencies that operate at the national, subnational and sectoral levels.

Medium-term structural reforms should focus on addressing critical gaps in human capital, facilitating economies opportunities for women and improving private sector opportunities to ensure sustainable and inclusive growth. Making greater gains in human capital development will require deeper reforms to improve the quality of learning through better pre-school services and improved inschool assessments, and to reduce childhood stunting with multi-pronged solutions. Facilitating equal access of economic opportunities for women would also yield significant gains in the long term (see Box 5). Among the policy priorities to overcome the key constraints preventing women from accessing productive jobs in Malaysia include expanding the availability, quality and affordability of child and elderly care; enhancing the protection and productivity of informal workers; and improving support for parents in line with international legal norms. Concurrently, policymakers should also sustain reform efforts to promote healthy market competition, strengthen public procurement and address distortions in labor and output markets to improve private sector participation in the economy.

\section{In a more uncertain economic environment, it is vital for Malaysia to preserve fiscal space to mitigate the impact of negative shocks to the economy.}

Policies to raise the incomes and economic security of lower-income segments of the population could be sharpened to ensure continuous improvement in the living standards for all Malaysians. While significant progress has been achieved in sustaining income growth and reducing poverty over the recent years, more can be done to address broad citizen concerns over economic security and the perceptions of stagnant living standards experienced by lowerincome households against a backdrop of increasing cost of living. To further advance the government's inclusive growth agenda, specific and practical policy measures could be formulated to tackle the overlapping factors that have contributed to such concerns. Among the dominant factors at play include spatial consumer price inflation differentials, slow wage growth among the youth, poor financial planning and indebtedness, and unaffordable housing, which are explored in more detail in Part 2 of this edition of the MEM. 


\section{How better economic opportunities for women could boost long-term economic development in Malaysia}

One of the most promising avenues to facilitate Malaysia's ongoing development involves the promotion of economic opportunities for women. World Bank simulations using a general equilibrium occupational choice model show that if the gaps between men and women in terms of labor force participation and entrepreneurship were closed, Malaysians' average per capita income could increase by up to 26 percent, or about RM9,400 (Cuberes and Teignier, 2019).

\section{A complementary tool that can be used to simulate the economic effects of improving women's labor force participation is the World Bank's Long- Term Growth Model (LTGM). The LTGM is based on the celebrated Solow-Swan growth model, adapted to developing/emerging market economies. In the model, higher rates of female labor force participation (FLFP) increase the total amount of labor supplied, thus boosting GDP. Historically, the FLFP rate in Malaysia was stable at around 46 percent, before increasing significantly to 55 percent in the period from 2010 to 2015. However, Malaysia's FLFP still lags both its regional and high-income peers, suggesting that there is room for reforms and measures to increase participation. Within ASEAN, only Myanmar, Indonesia and the Philippines record a larger gap between these rates (see Figure 37).}

In the business-as-usual baseline, FLFP is assumed to be constant at 55 percent, with GDP growth falling from 4.5 percent in 2020 to 2.0 percent in 2050 (see Figure 38). In part, the decline in the GDP growth rate is attributable to slowing population growth (about a fifth of the fall). More importantly, however, are declining returns on private investment (which were previously very high) and declining productivity growth, slowing human capital growth, and an aging population. A decline in GDP growth is

\section{FIGURE 37}

Malaysia shows a large gender gap when it comes to labor force participation

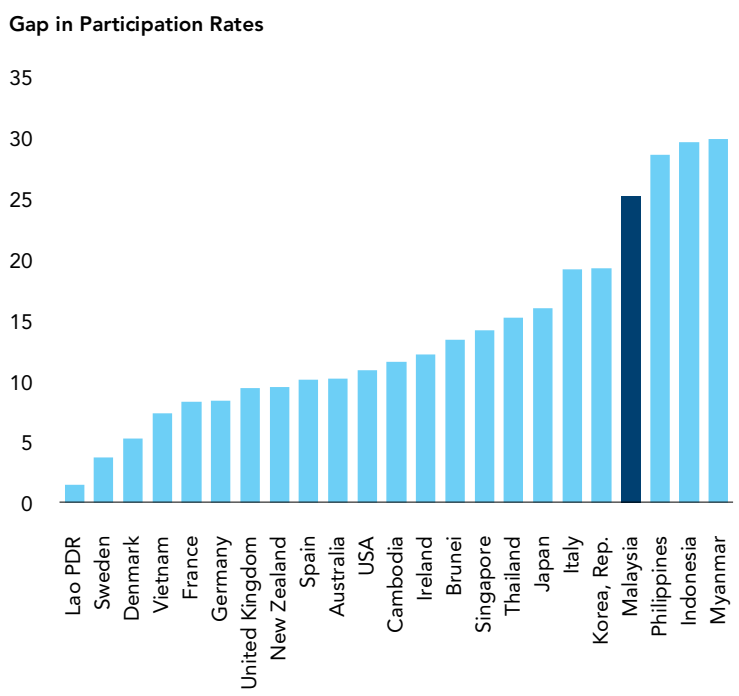

Source: World Bank staff calculations based on World Development Indicators.

Note. Modeled ILO estimates of the labor force participation rate among the population ages $15-64$

commonly observed as countries make the transition to high income country status, but it can also motivate new pro-growth reforms.

Reforms to increase FLFP to the 25th-75th percentiles of high-income economies boosts average GDP growth in the period from 2020 to 2050 by $0.14-0.36$ percentage points (see Figure 39). ${ }^{11}$ The simulation considers weak, moderate, and strong FLFP reform scenarios, with FLFP increasing to the 25th, 50th, and 75th percentiles among high income countries respectively in these scenarios. The length 
of the adjustment period is based on the historical experience of high-income countries as they increased FLFP. $^{12}$ In the case of weak reform, it takes 27 years to increase FLFP from 55 to 62 percent (FLFP of Croatia in 2018). This increases average GDP growth in the period from 2020 to 2050 by 0.14 percentage points, relative to the baseline. In the case of moderate reform, it takes 23 years to increase FLFP to 69 percent (Spain in 2018), which increases average GDP growth by 0.31 percentage points. In the case of strong reform, it takes 27 years to increase FLFP to 74 percent (Netherlands in 2018), which increases average GDP growth by 0.36 percentage points. ${ }^{13}$

An increase in Malaysia's FLFP to the 25th75th percentiles of high-income economies will require addressing key constraints on women's participation in the labor force, especially their involvement in housework and care duties. In 2018, 60.2 percent of women who did not participate in the labor force cited housework (which includes care of children and the elderly) as their main reason for not seeking work. In contrast, only 3.6 percent of inactive men cited the same reason for not seeking work. This is mainly because according to prevalent social

\section{FIGURE 38}

Reform scenarios to raise Malaysia's female labor force participation rate...

\section{Malaysia's Female Labor Force Participation Rate Under Different} Reform Scenarios, Percentage

80

70

60

50

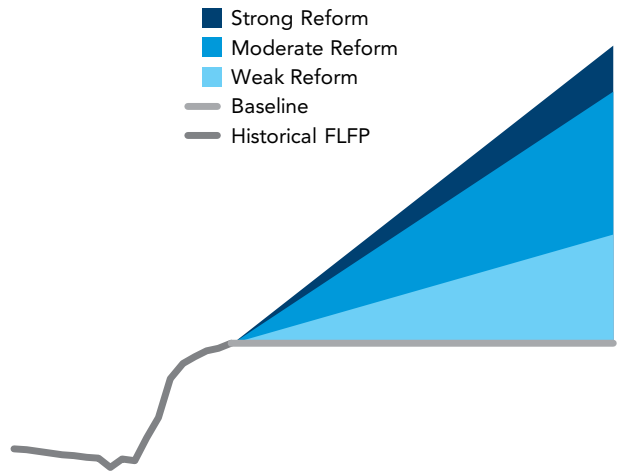

40

20002005201020152020202520302035204020452050 norms, women are seen as primarily responsible for the provision of care at home. Qualitative evidence from focus group discussions conducted by the World Bank and Universiti Kebangsaan Malaysia confirm that caring for children and the elderly is primarily seen as the responsibility of women (see World Bank 2019c).

Women from the B40 face particularly stark barriers to labor force participation, with limited access to jobs that pay well and offer benefits, social protection, and career prospects. Focus group discussions show that women from B40 families, including those living in urban poor areas such as Projek Perumahan Rakyat (PPR) public housing developments, often struggle to participate in the labor market because of a lack of access to affordable, good quality child care. Those in this group that do participate in the labor market very often work part-time in informal jobs; are self-employed; or have their own micro-businesses. In fact, in the period from 2010 to 2018, the proportion of women engaged in self-employment increased from 11.6 percent to 19.5 percent. While nonstandard forms of work provide flexibility to care for children and the elderly, they usually offer no social protection and little room for skill development and productivity growth.

\section{FIGURE 39}

\section{...have a major impact on GDP growth over the long term}

Malaysia's GDP Long Term Growth Rate Under Different Reform Scenarios Percentage

10

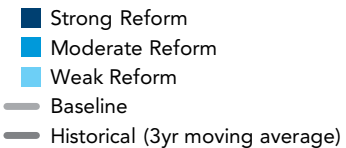

5

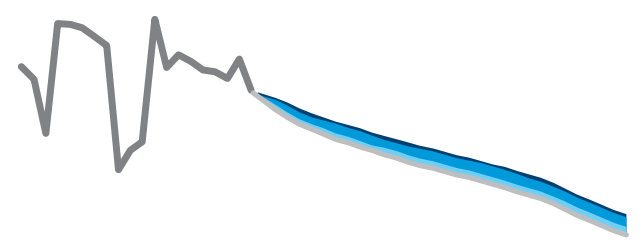
20002005201020152020202520302035204020452050

\footnotetext{
${ }^{12}$ Adjustment is assumed to continue linearly at its trend rate after the FLFP target is met. The start year for adjustment is 2018. The length of the adjustment period is based on the distribution of time that high-income countries took from Malaysia's FLFP rate to the target.

${ }^{13}$ The corresponding increase in GDP per capita is smaller than in the simulations by Cuberes and Teignier (2019) because, first, the increase in female labor force participation considered in the LTGM is smaller and, second, the LTGM does not consider an improvement in female entrepreneurship.
} 
"I think it's better to work in our own businesses. We have children who still go to school, so it's difficult to work 9 to 5. Our time is limited, so it's better to work on our own. I run my own small business, making banana chips and smoked banana [...]. I like to work on my own."

[Respondent F9, female, age 44, B20 focus group discussion 23]

"I live in [a specific part of a PPR]. We don't have any kindergartens there. [...] So, most of our children don't go to kindergarten. They usually go straight to elementary school. [Even if we had a kindergarten], they would not accept children of the age of 4 or 5 years. It's difficult. We don't even have a tuition center."

[Respondent F2, female, age 36, B20 focus group discussion 9]

Existing government policies and programs, including the new incentives provisioned under the Budget 2020, do not fully cover the child care needs of the B40, especially the urban poor. Key government initiatives include the promotion of flexible forms of work, the establishment of child care centers at workplaces, and the introduction of tax incentives for women returning to work. These are unquestionably important measures and are designed to encourage women's labor force participation regardless of their income level. As such, most of the measures have largely benefited women in M40 or T20 families, with relatively little relevance for women from B40 families who either are not able to participate in the labor market or who work in informal jobs and, in either case, pay no personal income tax (see Figure 40).

In a tight fiscal environment, it is crucial to prioritize the allocation of public resources to provide child care for B40 families. In this context, providing adequate allocations to establish and maintain child care centers in low cost urban housing areas, such as PPR flats, is vital. Additionally, a cost-effective, easy to implement measure may involve making use of and enhancing existing public structures such as schools, libraries and community centers to provide child care. Delivering quality child care for the B40 will also require close collaboration between a number of entities, including the Ministry of Women, Family and Community Development; the Ministry of Housing and Local Government; and state and local governments and their agencies. Finally, child care services should be gradually extended beyond the current focus on children aged from 0 to 6 years to cover children aged from 0 to 17 years.

If implemented correctly, the allocation of additional public resources to provide child care for the B40 is expected to benefit not only women, but also children and the economy more broadly. First, when children have safe, high quality play and learning

FIGURE 40

Mapping of existing government policies and programs

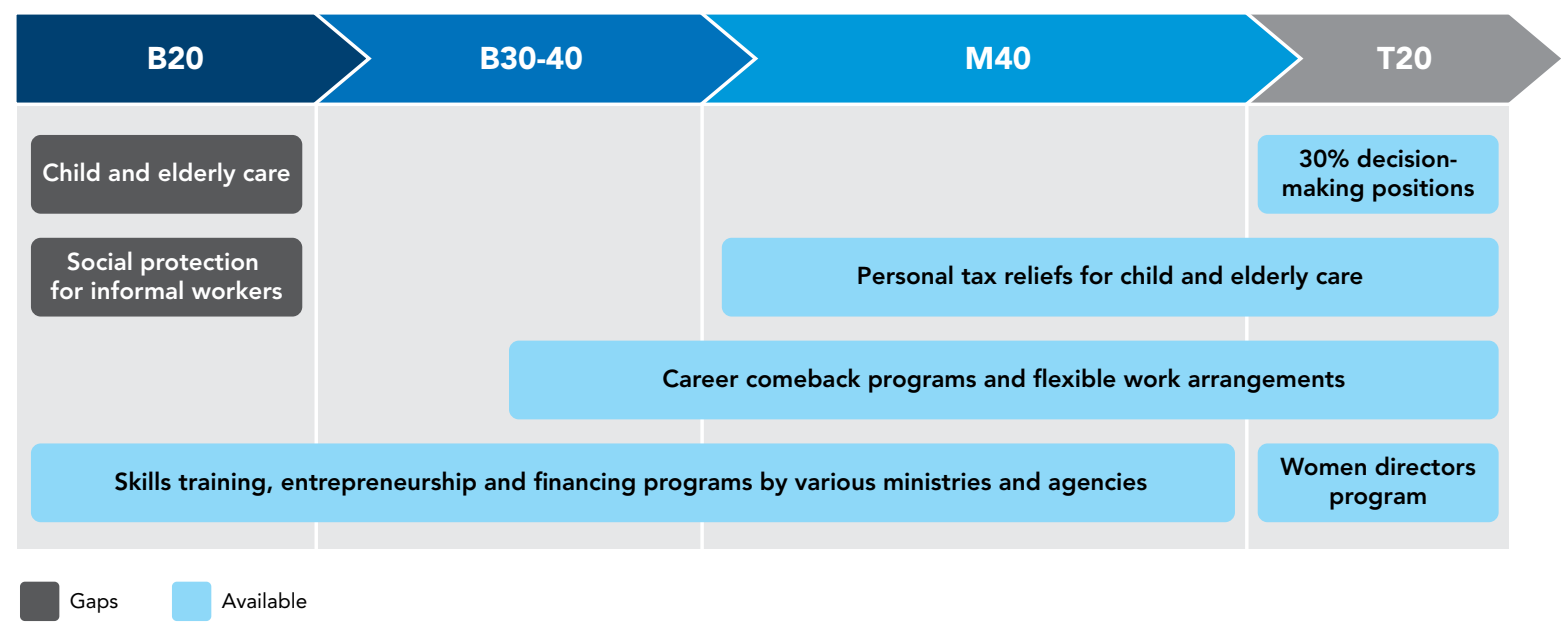

Source: Authors based on Ministry of Finance budget speeches from 2011 to 2018 and websites of various ministries and agencies. 


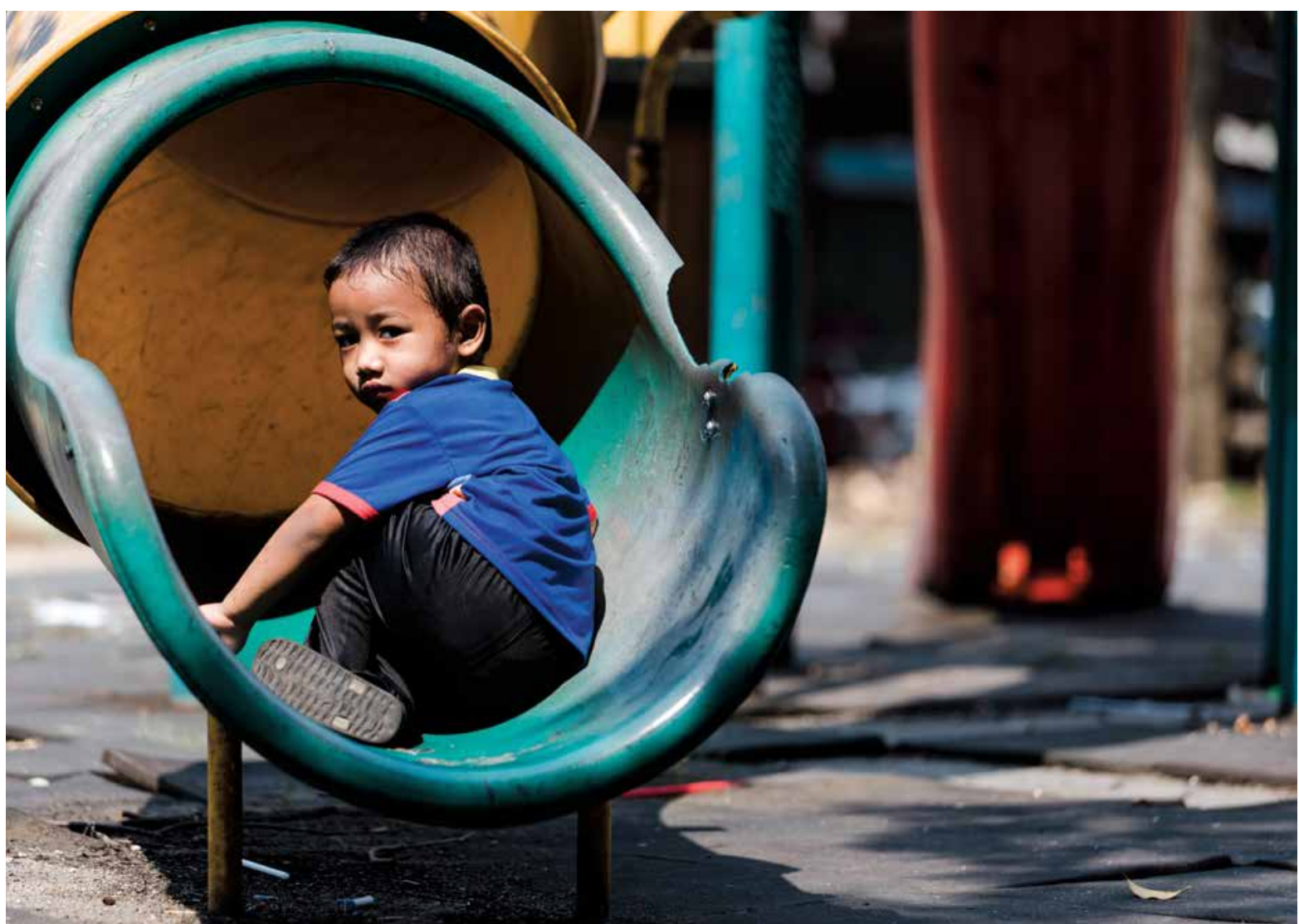

environments, they will enjoy better health and learning outcomes. Second, the provision of childcare will give both fathers and mothers the comfort and peace of mind to go to work, enabling households to generate dual incomes and increasing the rate of participation in formal employment (see IFC 2017). Third, employers are also likely to benefit as it will make it easier for them to attract and retain workers, reducing persistent labor market shortages.

Ultimately, the promotion of economic opportunities for Malaysian women will require the development of a comprehensive, multisectoral policy approach that addresses child care and other challenges and constraints in a systematic and mutually reinforcing manner. Addressing the lack of access to quality and affordable care for children and the elderly will be vital. In addition, specific policies are needed to provide benefits and social protection and to increase the incomes of informal workers. In addition, in a number of aspects, Malaysia's legal environment lags behind those of its peers in terms of implementing and enforcing laws and regulations related to gender equality. Similarly, there is room to improve parental benefits in line with international legal norms. Finally, greater efforts are needed to increase public awareness of Government support for working women and of their legal rights and obligations, and to address gender norms and attitudes in education and among the community at large.

As a means of facilitating the achievement of shared prosperity, promoting women's economic empowerment makes business, economic and social sense, particularly as Malaysia progresses towards becoming a highly developed and inclusive nation.

Notes. Baseline assumptions for key parameters and other growth drivers in the LTGM are: (i) a labor share of 50 percent; (ii) an initial capital-to-output ratio of 2.25; (iii) public and private investment of 6 percent and 18 percent of GDP (respectively); (iv) human capital growth declining from 0.6 percent to just under 0.1 percent by 2050; (v) TFP growth declining from 0.9 percent to 0.6 percent by 2050; (viii) population growth declining from 1.3 percent to 0.4 percent by 2050 . Source for LTGM: Loayza and Pennings (2018), http://www.worldbank.org/LTGM. 



\section{Making ends meet}

\section{Many factors influence the ability of households to make ends meet}

Despite Malaysia's low and stable inflation rate, there has been an ongoing debate regarding perceived increases in the cost of living in the country. These concerns are frequently expressed in public policy debates, in the mass media, and in private conversations. The issue has featured prominently in public and private discourse for years, dating back at least to the introduction of the GST in April 2015 and the fuel subsidy rationalization in December 2014. And more recently there has been a robust public debate about whether Malaysia should increase its nationallydefined poverty line. It is particularly noteworthy that these concerns have emerged during a period of low inflation, with the headline inflation rate averaging around 2 percent since 2015 (except in 2017 when it was 3.8 percent), well below the growth rates for the economy and average nominal income.

In this context, the "cost of living" is often used as a catch-all term that may reflect wider developments in the economy and their impacts on household budgets and well-being. While the discussion is usually framed as an issue of rising costs for goods and services, for most Malaysians, the core issues extend beyond prices. These include lagging income growth and increasing levels of household debt, which result in lower disposable income and inadequate financial savings. In addition, increasing home prices also feed into these concerns.

The special topic in this edition of the MEM is titled Making Ends Meet and aims to comprehensively examine evidence and perceptions related to the cost of living in Malaysia. Using a household-centric perspective, it identifies four factors that contribute in varying degrees to households' ability to make ends meet. While these factors overlap somewhat and are by no means exhaustive, they include the following: (i) consumer price inflation differentials linked to income levels and/or geographic location, (ii) inadequate income, (iii) declining financial well-being, and (iv) insufficient access to affordable housing.

The underlying premise of the analysis is that the cost of living affects individual households differently, depending on a range of factors including demographics, location and employment. Organizing the analysis along these lines also enables us to identify practical policy measures to address economic hardships related to perceptions regarding the cost of living.

\section{Overall, price increases for most goods and services have been low and stable}

Changes in the consumer price index show that inflation in Malaysia has been moderate in recent years. This is especially true for core inflation, which excludes items with more volatile prices (especially energy and food commodities) as well as items with administered prices and the estimated direct impact of changes in consumption tax policy. Core inflation has been running at 3 percent or less (year-on-year) since mid-2016, and headline inflation has tracked it closely except during 2017, when higher food and fuel prices pushed headline inflation into the 3-4 percent range (see Figure 41). As in most countries, monetary policy in Malaysia aims to facilitate the achievement of low and stable rate of consumer price inflation 
that is compatible with economic growth objectives. Bank Negara Malaysia's Consumer Sentiments Survey indicates that Malaysians do expect prices to increase, and that on average their expectations regarding the inflation rate are about 1.5 percentage points higher than the actual rate (BNM, 2019).

The CPI is sometimes criticized as not being an accurate measure of the costs that people face every day. DOSM calculates the CPI following internationally recommended practices, using a reference "basket" of consumer goods and services. The composition of the basket is determined by the average consumption patterns of Malaysian households as recorded in the Household Expenditure Survey (HES) and updated regularly. The estimated cost of the $\mathrm{CPI}$ reference basket is calculated each month using the average prevailing prices of the items in the basket, based on a price survey covering more than 500 items in more than 20,000 locations throughout Malaysia.

While the CPI may be a valid measure of average trends in consumer prices, it has at least two inherent limitations as a tool for examining the cost of living. First, the CPI is a summary measure based on average consumption patterns and average prices, and the real price changes that individuals experience will be higher or lower than that average. For example, lowerincome households spend a higher share of their family budget on food, so they will experience higher inflation when food prices rise faster than prices of other items. In recent years these differences have been relatively small, as shown by the price index that DOSM publishes

\section{FIGURE 41}

Inflation has been moderate and stable, especially core inflation...

Inflation Rate, $y / y$, Percentage

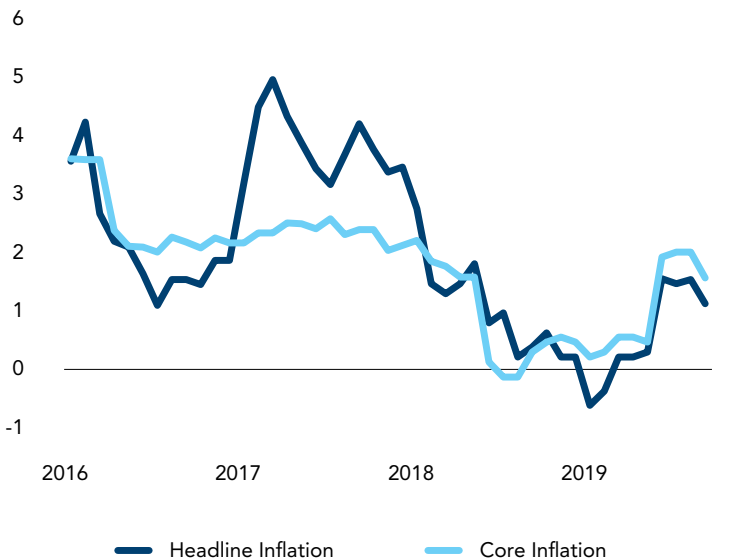

Source: Monthly CPI reports (DOSM) based on consumption patterns of households with monthly incomes less than RM3,000. Second, the CPI focuses on consumption items, and excludes living costs that have a high investment component, such as the cost of buying a house or condominium. Housing prices have risen rapidly in Malaysia, especially during 2013 to 2016, and this is not reflected in the CPI. The contribution of housing to increases in the cost of living is discussed in detail in a subsequent section.

The ways that prices change can also lead people to think that inflation is higher than it really is (see Figure 42). Recent analysis by Bank Negara Malaysia investigates how subconscious biases may affect consumers' inflation perceptions. For example, "frequency bias" leads people to be more influenced by changes in the prices of items that are purchased frequently, such as fresh food, dining out, highway tolls and fuel. Likewise, "memory bias" makes consumers more inclined to notice, and remember, price increases than price decreases. The Everyday Price Index (EPI) examines the magnitude of frequency bias by using a reference basket comprising only items purchased at least once per month (BNM 2019). The Perceived Price Index (PePI) goes a step further, using a basket of those same frequently-purchased items that are in the EPI, but counting only price increases and excluding price decreases. Frequency bias is relatively small in Malaysia, as the EFI closely tracks the standard CPI, especially during 2018. In contrast, the PePI shows that the memory bias that gives disproportionate weight to price increases is large, with the PePI exceeding the $\mathrm{CPI}$ by 7 to 14 percentage points.

\section{FIGURE 42}

...although perceptions of inflation may be higher because of frequency and memory biases

Inflation Rate, $y / y$, Percentage

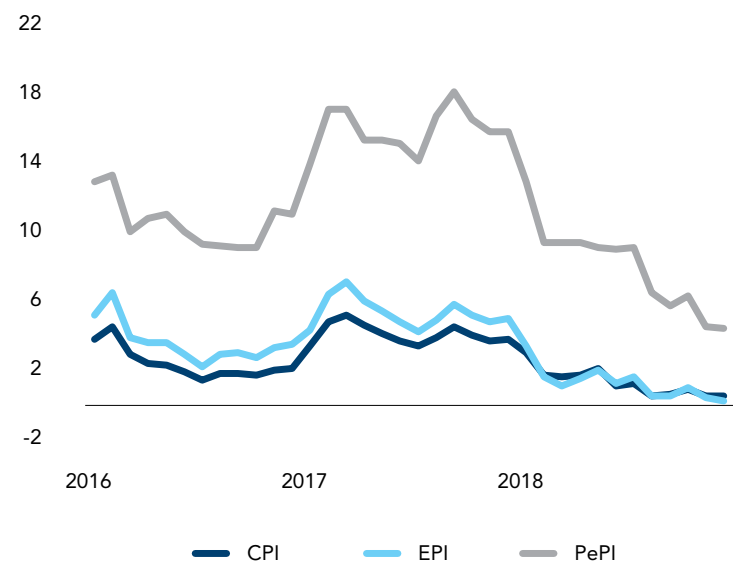

Source: BNM (2019) 


\section{Living costs vary significantly across Malaysia}

\begin{abstract}
While the evolution of prices over time in Malaysia is well measured and documented, comparatively little attention is given to the large differences in price levels across places. Moving around the country it is readily apparent that some places are more expensive in general than others, and also that there is usually a locally-produced specialty that is unusually inexpensive. The most obvious spatial price differences are in housing, but there is also significant spatial price variation across a wide range of common goods and services, as seen in the examples in Table 5, where it is not unusual for the average price in one state to be almost twice as high as that in another state, with some interesting patterns. Fresh food items such as spinach and coconut milk are least expensive in Kuala Lumpur and relatively expensive in Sabah and Sarawak, while the opposite is true of brinjal and bananas. Services, such as haircuts, tend to be more expensive in more urbanized states, with the exception that the most expensive haircuts are in Sabah, one of the more rural states. The average price for a 40 -inch television is significantly higher in Sabah and Sarawak than in peninsular Malaysia.
\end{abstract}

Because of spatial price differences, the purchasing power of a ringgit varies from place to place, which directly impacts the cost of living. It is no secret that Johor, Kuala Lumpur and Selangor are Malaysia's highcost environments, and that costs tend to be lower in states such as Kedah, Kelantan and Perlis. If household incomes varied across these areas in exactly the same proportion as costs then that would neutralize the effect of spatial price differences on the cost of living. However, incomes do not vary in the same way, especially if one looks beyond the averages. As one example, consider that the income eligibility requirements and the benefits for BSH are uniform across Malaysia. This implies that in real income (purchasing power) terms, the BSH program excludes needy people in high-cost areas and includes less-needy people in low-cost areas. Furthermore, the BSH cash benefit buys less in high-cost areas. Similarly, with a uniform national minimum wage (RM1,100 as of 2019) a minimum wage earner in high-cost Johor will not be able to achieve the same standard of living as her minimum wage counterpart in Kedah. ${ }^{14}$
In many countries, spatial price indices are calculated and published to help both the public and private sectors incorporate spatial price differences in their decision making. The CPIincluding the state-level CPIs that DOSM has published since 2013-is a temporal price index, that is, one that measures the change in the cost of the reference consumption basket relative to a fixed point in time, or base period. A spatial price index (SPI) is similar in construction, except that it measures differences in the cost of the reference basket across different places at the same point in time. At the international level, the Purchasing Power Parity estimates of the International Comparison Project are a form of SPI, as are the Purchasing Power Standards produced by Eurostat for the member states of the European Union. At the national and sub-national levels, the US Bureau of Economic Analysis publishes an SPI known as Regional Price Parities, which measure differences in prices across the 50 states, as well as for individual metropolitan areas. Likewise, Statistics Canada produces an SPI for living costs in 34 communities of Alberta relative to the provincial capital, Edmonton. The main practical use of these indices is simple and powerful: to convert calculations of nominal income to "real income", which takes into account spatial differences in living costs, and more closely approximates the level of economic well-being.

Malaysia does not currently report a spatial price index, although spatial aspects are likely to be incorporated in the cost of living index being developed under the National Cost of Living Action Council (NACCOL). Despite the absence of a standard $\mathrm{SPI}$, it is possible to get a rough approximation of how much spatial price differences influence the cost of living using a special-purpose SPI that Malaysia already has: the Poverty Line Income (PLI). As a form of SPI, the PLI measures the cost of a fixed basket of goods and services in different places at the same point in time. Where the PLI differs from a typical SPI is the composition of the reference basket, which is based on the average consumption of poor people, as opposed to the average of the population. ${ }^{15}$ In Malaysia's case these are very basic goods and services, currently corresponding

\footnotetext{
${ }^{14}$ The 2020 budget speech announced a RM100 increase in the minimum wage for those in major cities.

${ }^{15}$ It would be straightforward to calculate an SPI based on the CPI reference basket using currently unpublished aggregate data from the CPI price surveys. These
} data were not available to use in this report, hence the decision to use the PLI-based SPI as a next-best alternative. 
TABLE 5

Average prices in RM for selected goods and services by state

\begin{tabular}{|c|c|c|c|c|c|c|}
\hline & $\begin{array}{l}\text { Spinach } \\
(\mathrm{kg})\end{array}$ & $\begin{array}{l}\text { Coconut } \\
\text { milk (kg) }\end{array}$ & $\begin{array}{c}\text { Brinjal } \\
(\mathrm{kg})\end{array}$ & $\begin{array}{c}\text { Golden } \\
\text { bananas (kg) }\end{array}$ & $\begin{array}{l}\text { Men's } \\
\text { haircut }\end{array}$ & $\begin{array}{l}\text { 40" LED } \\
\text { television }\end{array}$ \\
\hline Johor & 4.13 & 9.00 & 6.53 & 4.30 & 11.55 & $1,415.17$ \\
\hline Kedah & 3.74 & 11.50 & 6.08 & 5.25 & 8.66 & $1,457.88$ \\
\hline Kelantan & 4.29 & 9.77 & 5.34 & 5.10 & 6.63 & $1,163.65$ \\
\hline Melaka & 3.89 & 10.93 & 7.32 & 4.75 & 10.80 & $1,344.00$ \\
\hline Negeri Sembilan & 3.57 & 9.41 & 6.80 & 4.97 & 9.94 & $1,299.50$ \\
\hline Pahang & 3.77 & 13.17 & 6.59 & 4.55 & 11.22 & $1,444.00$ \\
\hline Perak & 3.49 & 10.41 & 5.94 & 4.34 & 9.61 & $1,362.67$ \\
\hline Perlis & 4.80 & 10.88 & 5.86 & 6.00 & 11.00 & $1,396.00$ \\
\hline Pulau Pinang & 3.64 & 11.05 & 6.04 & 5.59 & 10.55 & $1,391.18$ \\
\hline Sabah & 4.27 & 9.50 & 4.38 & 3.15 & 12.36 & $1,527.75$ \\
\hline Sarawak & 6.05 & - & 7.17 & 3.21 & 10.46 & $1,506.81$ \\
\hline Selangor & 3.39 & 10.72 & 6.40 & 5.34 & 12.18 & $1,352.85$ \\
\hline Terengganu & 5.27 & 10.00 & 5.89 & 5.68 & 10.64 & $1,414.33$ \\
\hline WP Kuala Lumpur & 3.44 & 7.22 & 6.71 & 5.65 & 11.34 & $1,341.50$ \\
\hline WP Putrajaya & 4.90 & 12.00 & 7.89 & 5.72 & 12.00 & $1,298.00$ \\
\hline Malaysia & 4.23 & 10.23 & 6.10 & 4.33 & 10.78 & $1,412.94$ \\
\hline Ratio of highest to lowest prices & 1.78 & 1.82 & 1.80 & 1.90 & 1.86 & 1.31 \\
\hline
\end{tabular}

Source: Consumer Price Index Report, September 2019 (DOSM, 2019)

approximately to the consumption patterns of the poorest 1 percent of the population (for details of the $\mathrm{PLI}$ basket composition see EPU/UNDP, 2007).

Even for a very basic consumption basket, the cost can vary by almost 70 percent depending on where you live in Malaysia. After controlling for household composition, the lowest cost of the PLI basket is in Kelantan, and the highest is in Kuala Lumpur and Putrajaya. Table 6 shows the spatial price differences in different parts of Malaysia for the very basic PLI basket as a percentage of the PLI in rural Kelantan. As expected, costs in more urbanized states and federal territories tend to be higher than in more rural states. In addition, prices are mostly lower in the northern states of peninsular Malaysia. Both rural and urban Sabah, and to a lesser degree Sarawak, stand out as having high prices for basic consumption items, not far below the three Federal Territories and higher than Pulau Pinang and in some cases Selangor.

This implies that because of spatial price differences, substantially higher incomes are needed to achieve the same standard of living in urban areas, Sabah and Sarawak than in other areas. If one applies the spatial price indices in Table
6 to a more reasonable living standard than the PLI it can be said that it takes an income of approximately RM4,300 in rural Sabah reach the same standard of living that RM3,000 will buy in rural Kelantan. In fact, the SPI derived from the PLls almost certainly underestimates the size of these differences, because the PLI reference basket has a high proportion of price-controlled items. A basket based on the consumption of average consumers would have a lower share of expenditure on pricecontrolled items and therefore higher price variability between high-cost and low-cost areas.

Although household incomes tend to be higher in high-cost areas, in many places the extra income is probably not enough to fully offset higher prices. The PLI-based SPI presented here is a sub-optimal approximation of the price differences faced by average consumers across different areas in Malaysia, and the adoption of a proper SPI would be a welcome development. However, despite its limitations, the PLIbased SPI can provide an indicative view of how much spatial price differences are compensated for by spatial price differences in incomes. Nominal household incomes from the 2016 HIS were converted to real incomes that reflect local purchasing power. Figure 43 plots median household income for individual states 
TABLE 6

Cost of purchasing the standard PLI consumption basket by state and urban/rural area, as a percentage of the cost in rural Kelantan

\begin{tabular}{|c|c|c|}
\hline & Urban & Rural \\
\hline Johor & $131.8 \%$ & $114.0 \%$ \\
\hline Kedah & $122.5 \%$ & $110.6 \%$ \\
\hline Kelantan & $113.6 \%$ & $100.0 \%$ \\
\hline Melaka & $130.1 \%$ & $115.3 \%$ \\
\hline Negeri Sembilan & $125.0 \%$ & $122.0 \%$ \\
\hline Pahang & $128.0 \%$ & $115.7 \%$ \\
\hline Perak & $122.5 \%$ & $111.4 \%$ \\
\hline Perlis & $117.4 \%$ & $110.2 \%$ \\
\hline Pulau Pinang & $140.7 \%$ & $125.4 \%$ \\
\hline Sabah & $148.7 \%$ & $143.2 \%$ \\
\hline Sarawak & $139.8 \%$ & $130.1 \%$ \\
\hline Selangor & $143.2 \%$ & $122.0 \%$ \\
\hline Terengganu & $124.2 \%$ & $116.9 \%$ \\
\hline WP Kuala Lumpur & $166.9 \%$ & - \\
\hline WP Labuan & $148.7 \%$ & $143.2 \%$ \\
\hline WP Putrajaya & $166.9 \%$ & - \\
\hline
\end{tabular}

Source: World Bank staff calculations based on PLI values provided by DOSM

and Federal Territories against the estimated increase or decrease in purchasing power when spatial price differences are taken into account, with urban areas shown in dark blue and rural areas in light blue. In the areas below the zero line-Kuala Lumpur, Putrajaya, Labuan, Sabah, and urban areas of Pulau Pinang, Sarawak, and Selangor-real income is lower than nominal income, meaning that local purchasing power is less than one would think before taking spatial price differences into account. The opposite holds for places above the zero line-predominantly rural and lowerincome-where prices are relatively lower and therefore real household incomes are higher than nominal incomes. Meanwhile, Sabah and urban Sarawak have the challenging combination of below-average mean incomes and above-average prices for basic goods and services.

FIGURE 43

Higher incomes in some urban areas are offset substantially by reduced purchasing power because of higher prices, while lower rural incomes get a boost from lower prices

Estimated Median Gain/Loss in Household Purchasing Power from Spatial Price Differences in 2016, RM per Month

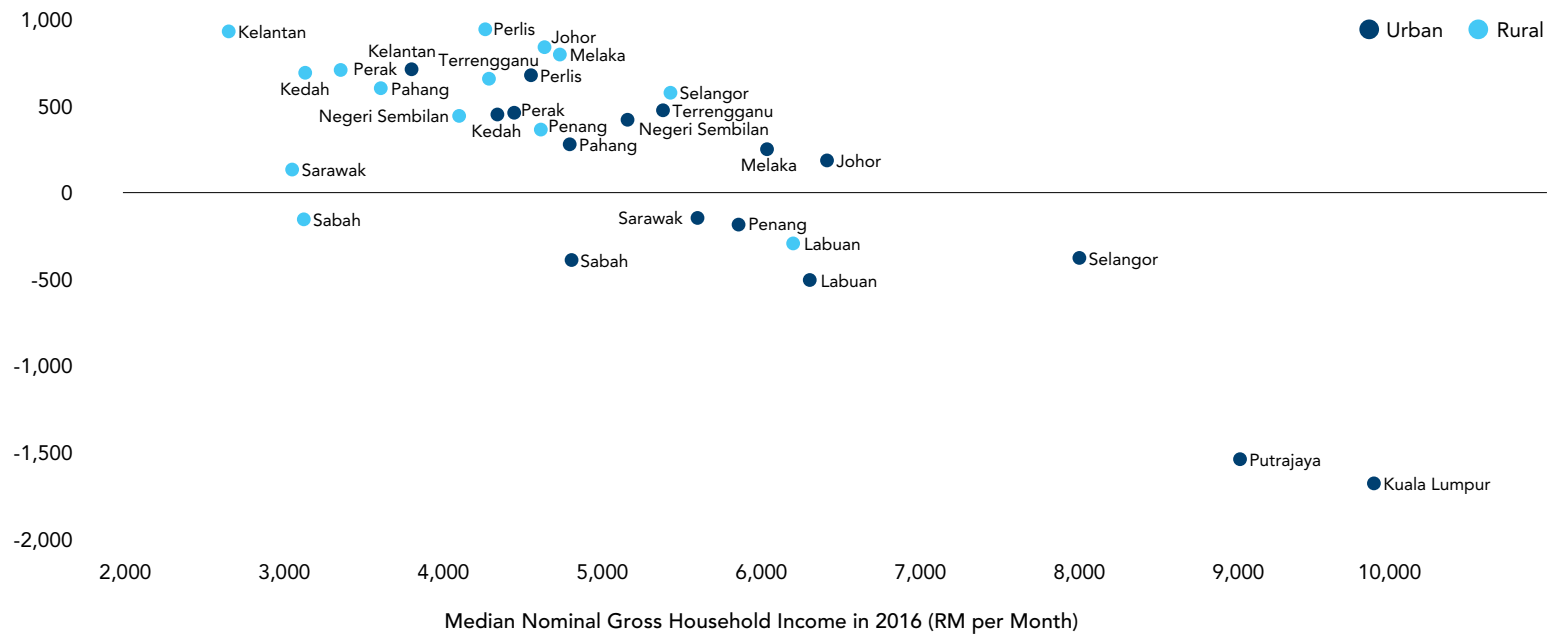




\section{Many Malaysians, especially in urban areas, feel their income is insufficient to raise their living standards}

As of 2018, nearly 30 percent of Malaysians felt that they did not have enough money for food and 23 percent reported having inadequate money for shelter. Based on the Gallup World Poll (GWP) ${ }^{16}$ the number of Malaysians who felt that they do not have enough money for food has doubled since 2012 (see Figure 44). This was more prominent among those living in urban areas where the poll results more than tripled from 8.6 percent to 28.7 percent. ${ }^{17}$ In rural areas, those feeling that they do not have enough money for food rose from 18.6 percent to 30 percent. Similarly, the number of urban residents indicating that they did not have enough money for shelter more than tripled, increasing from 7.4 percent to 24.8 percent since 2012 (see Figure 45). Although high housing costs are typically seen as an urban issue, it is noteworthy that 17-18 percent of rural residents reported not having enough money for shelter in 2012 and 2018.

FIGURE 44

The percentage of Malaysians who felt that they do not have enough money for food has doubled since 2012

Number of Respondents, Percentage

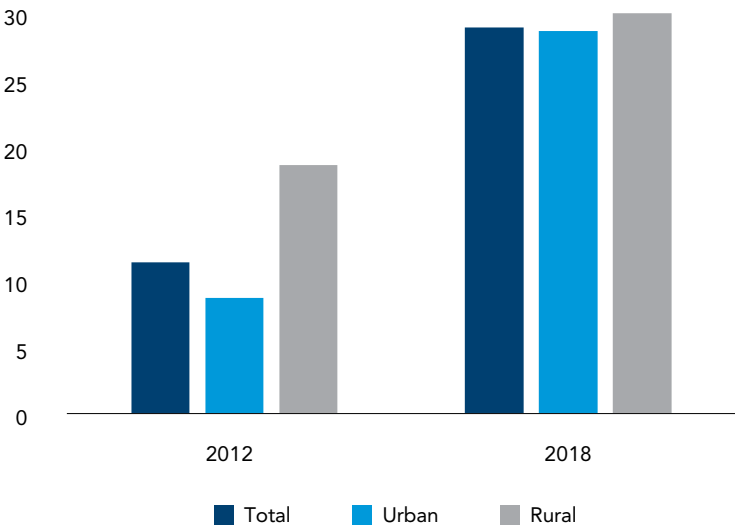

Source: Gallup World Poll
There is increasing dissatisfaction among the urban population with regard to their living standards. Between 2012 to 2018, the GWP results show that the number of Malaysians living in urban areas who reported an improvement in their living standards rose by 5 percentage points, from 54.1 to 59.4 percent (see Figure 46). Yet within the same period, the number of urban Malaysians who are satisfied with their standard of living declined from 76.5 percent in 2012 to 69.5 percent in 2018 (see Figure 47). There are various ways to interpret these results; one plausible explanation is that even though urban respondents' standards of living are improving by their own assessments, they are increasingly dissatisfied because their standards of living are not improving as fast as they would like (see Box 6). In contrast, in the rural areas, while a larger percentage responded that living standards have declined, the level of satisfaction with living standards increased from 2012 to 2018.

\section{FIGURE 45}

The percentage of urban residents indicating insufficient money for housing more than tripled from 2012-2018

Number of Respondents, Percentage

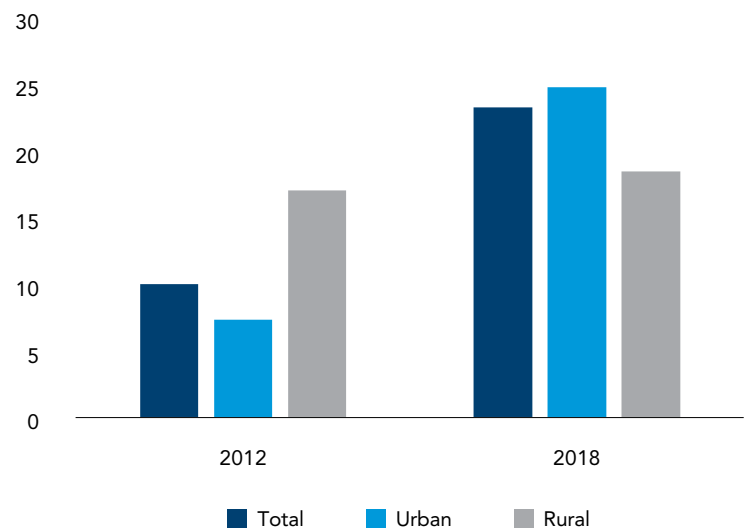

Source: Gallup World Poll

\footnotetext{
${ }^{16}$ The Gallup World Poll is conducted periodically in more than 150 countries, interviewing nationally-representative samples using a standard set of core questions, which are sometimes augmented by region-specific questions. The survey collects respondents' views on a range of social and economic issues, including employment, well-being, affordability of food and shelter, education, law and order, institutions and infrastructure. The GWP has been carried out in Malaysia 11 times from 2006 to 2018. In most of those years the GWP interviewed 1,000 randomly-selected individuals, which is the GWP norm; the only exception was 2014, when 2,000 individuals were interviewed.

17 The GWP constructs food and shelter indices based on the questions "Have there been times in the past 12 months when you did not have enough money to buy food that you or your family needed?" and "Have there been times in the past 12 months when you did not have enough money to provide adequate shelter or housing for you and your family?".
} 


\section{FIGURE 46}

The number of Malaysians in urban areas who have reported an improvement in living standards has increased...

Number of Respondents, Percentage

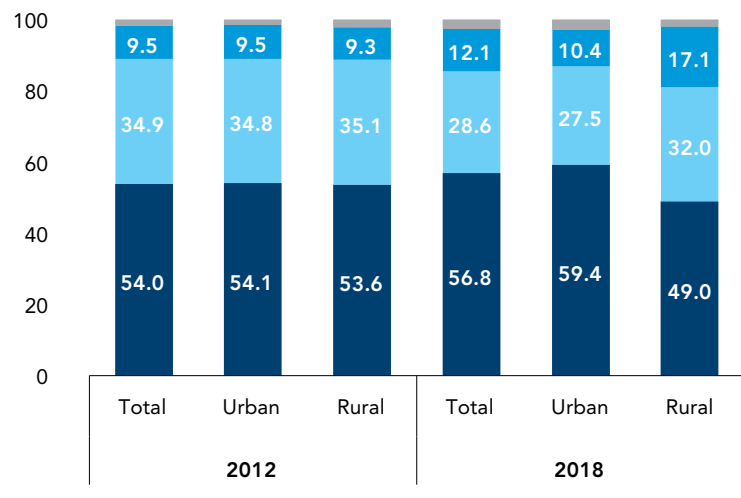

Getting better Getting worse The same Don't know

Source: Gallup World Poll

From 2012 to 2018, both urban and rural Malaysians have felt growing hardship in their life conditions. The GWP asked respondents to assess their current and future life conditions on a scale from 0 to 10 , where 0 is the worst possible life and 10 is the best possible life. From their answers, respondents are categorized as thriving, struggling or suffering. Based on the results, the percentage of urban respondents who are considered to be thriving dropped sharply,

\section{FIGURE 47}

...yet the number of urban Malaysians who are satisfied with their living standards has declined

\section{Number of Respondents, Percentage}

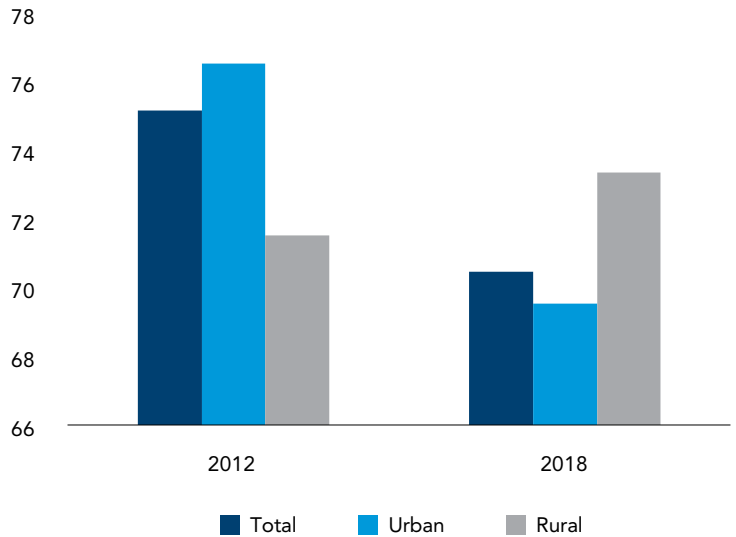

Source: Gallup World Poll

from 28.0 percent to 16.2 percent between 2012 and 2018 (see Figure 48). This was matched by increases of 9 and 3 percentage points of those who are categorized as struggling and suffering, respectively. Over the same period, the share of rural respondents who are thriving increased slightly from 20.6 to 21.8 percent, but the proportion reported as suffering also rose by 6.4 percentage points.

\section{FIGURE 48}

The number of urban Malaysians who felt that they are thriving declined sharply from 2012 to 2018

\section{Number of Respondents, Percentage}

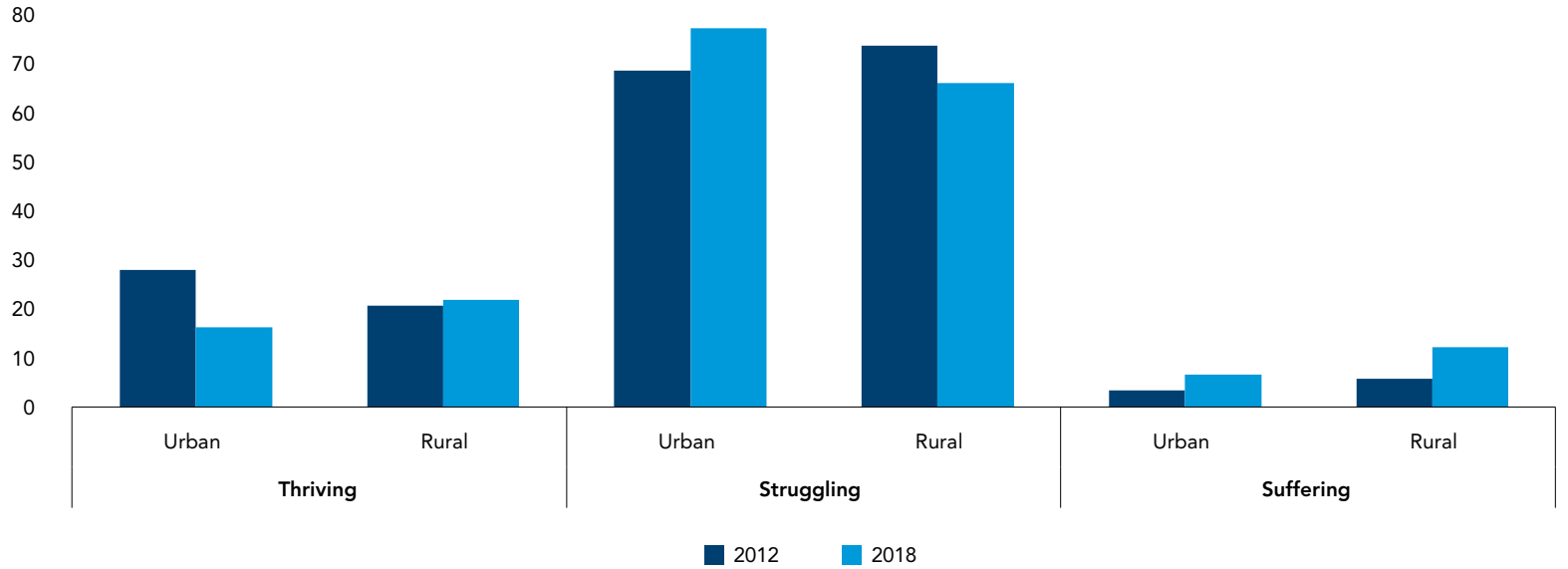




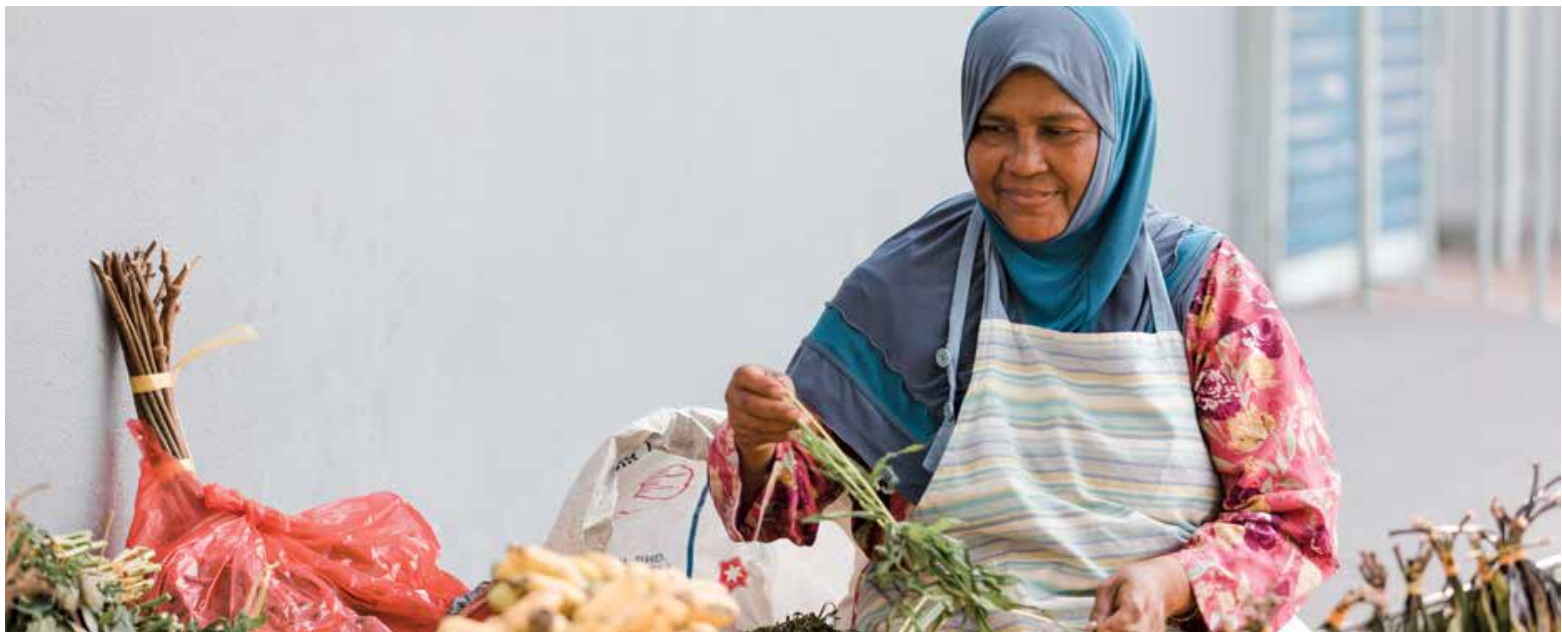

\section{Income, cost of living, and overall well-being}

Results from a qualitative study on living standards conducted by the World Bank and University of Malaya in 2019 with B20, B21-40, and M4018 Bumiputera, Chinese and Indians overwhelmingly support the finding that there is growing dissatisfaction among the urban population. Participants felt that their lives were "not in balance", because salaries were not keeping up with the cost of living, leading to increased hardship and stress. When asked whether their lives were easier, harder, or the same currently versus 5 years ago, 56 percent of participants across 56 focus groups in the Klang Valley, Terengganu and Sabah said that their lives were harder now compared to 5 years ago. ${ }^{19}$

"I have experienced a time when I earned RM900 to feed nine children. Now, the salary is not going up. The only thing going up is the cost of living. It is not in balance."

[Klang Valley, Bumiputera, B21-B40]

"When I joined ten years ago, my salary was RM500. Now I earn RM2000. It took ten years for me to get here. But the gap between the salary increase and the rise in cost of living is not balanced. I am struggling to even earn this low salary."

[Klang Valley, Indian, B21-B40]
"The costs going up is not a problem, but the wages must go up proportionately. This is not happening." [Klang Valley, Chinese, M40]

Malaysians of all three main ethnic groups also expressed a common sentiment: while material comforts had improved considerably compared to their parents' generation, there was not a concomitant increase in overall well-being. This sentiment was most acutely expressed by participants belonging to the M40 income groups, as the quotes below illustrate.

"Something that can be provided physically, yes, we children are better off. But something that is about the mind and the soul, we are not better off." [Klang Valley, Chinese, M40]

"In the past, we just lived comfortably by rewarding ourselves with good food for working hard. It was that simple. Now we have different needs and wants. We are suffering."

[Klang Valley, Bumiputera, M40]

"In the days of our parents, life was very happy. Even if we had few things and small houses, we were happy. Now, even with a three-storied house, we cannot sleep in peace."

[Klang Valley, Indian, M40]

${ }^{18}$ Income categorization is based on focus group participants' estimates of their household income and calibrated using net household income from the 2016 HIS subtracting income components that respondents would not typically include, such as imputed rent and employers' share of EPF contributions.

${ }^{19}$ These data are from participant responses in 56 focus group discussions from Klang Valley, Terengganu and Sabah. They are not representative for all of Malaysia. 


\section{Lower-income households' income growth has slowed considerably in recent years}

Real household incomes have been growing steadily, with the most rapid increase from 2009 to 2014, including exceptionally high growth rates for lowerincome households. During this period, quantitative data from the DOSM's household income surveys (HIS) show that mean and median household incomes have consistently grown faster than consumer price inflation. After adjusting for inflation, median monthly gross income per household grew from RM3,128 in 2002 to RM5,681 in 2016, an increase of 82 percent in real terms (see Figure 49). ${ }^{20}$ Growth incidence curves show widely varying patterns of the rate of income growth across the income distribution between 2002 to 2016 . After low growth of about 2 percent across all income groups between 2002 and 2009, annual growth in real mean household income increased sharply to 6.4 percent from 2009 to 2012, with rates exceeding 10 percent among the bottom 20 percent of the income distribution (see Figure 50). Growth in real household income was even more favorable in 2012-2014, with annual growth rates of 7.4 and 10.0 percent for mean and median income, respectively, and double-digit growth rates for households in the bottom 40 percent of income distribution.

FIGURE 49

Growth in real household income was favorable in 2012-2014

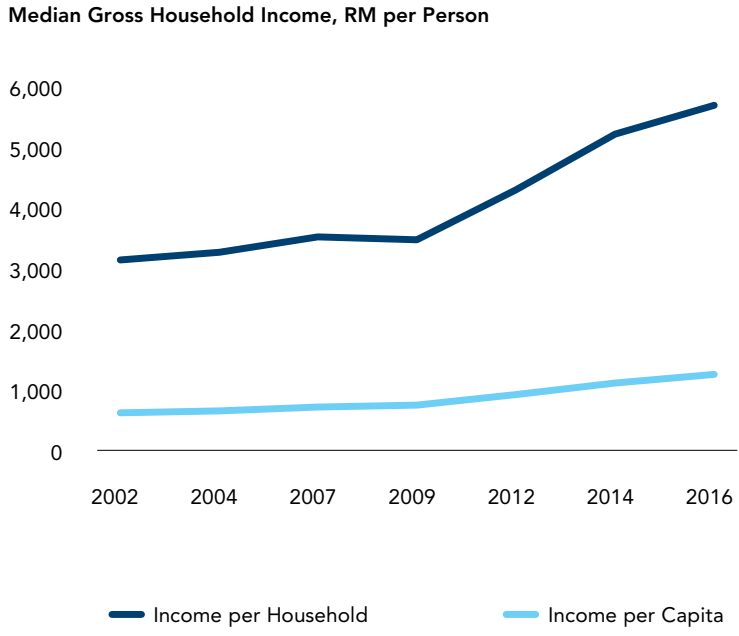

Source: World Bank staff calculations using Household Income and Basic Amenities Survey (DOSM)
More recently, however, households' income growth has slowed considerably for lower-income households. From 2014 to 2016, not only did overall household income growth slow to 5.5 percent, but lower-income households were no longer catching up even in relative terms, as income growth rates among the M40 were slightly higher than those of the B40 (see Figure 50). To the extent that accelerated income growth from 2009 to 2014 for the B40 and M40 shaped households' expectations about future income growth, they may possibly view the slower and less inclusive growth from 2014 to 2016 as a disappointment, which could in turn affect perceptions about increases in the cost of living.

In addition, even when income growth rates were higher among lower-income households, the absolute gaps across income groups continued to increase, which could contribute to perceptions of being "left behind". It is very common for lower-income households' absolute income gains in currency terms to be less than that of higher-income households because of their lower base income, even when the lowerincome households' incomes are growing at a faster

\section{FIGURE 50}

From 2009 to 2014, real mean household income growth was fastest among the B40

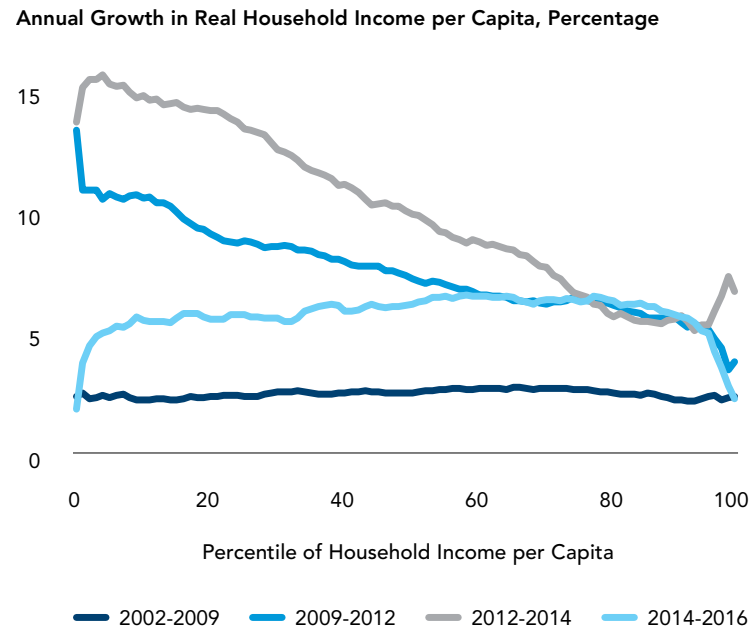

Source: World Bank staff calculations using Household Income and Basic Amenities Survey (DOSM)

${ }^{20}$ Incomes in this section are adjusted for inflation using the CPI and expressed in constant ringgit as of April 2017, which is the final month of data collection for the 2016-2017 Household Income Survey. 
relative rate. For example, during 2012 to 2014, mean incomes of the $\mathrm{B} 40$ were growing at about 13 percent per year while those of the T20 were growing at around 6 percent. However, because of B40 households' lower initial incomes, this only translated into an average gain of RM132 per month for them, compared to RM356 per month among the T20 (see Figure 51). These increases in absolute income gaps may contribute to perceptions of being "left behind" even during periods such as 2009 to 2014, when lower-income households were gaining a larger share of total income because their incomes were increasing more rapidly than their richer counterparts. Naturally, this perception would likely be amplified, and fully justified, in periods such as 2014 to 2016 , when the income gap between the B40 and the M40 increased in both absolute and relative terms.

\section{FIGURE 51}

The absolute gaps across income groups continued to increase, which could contribute to perceptions of being "left behind"

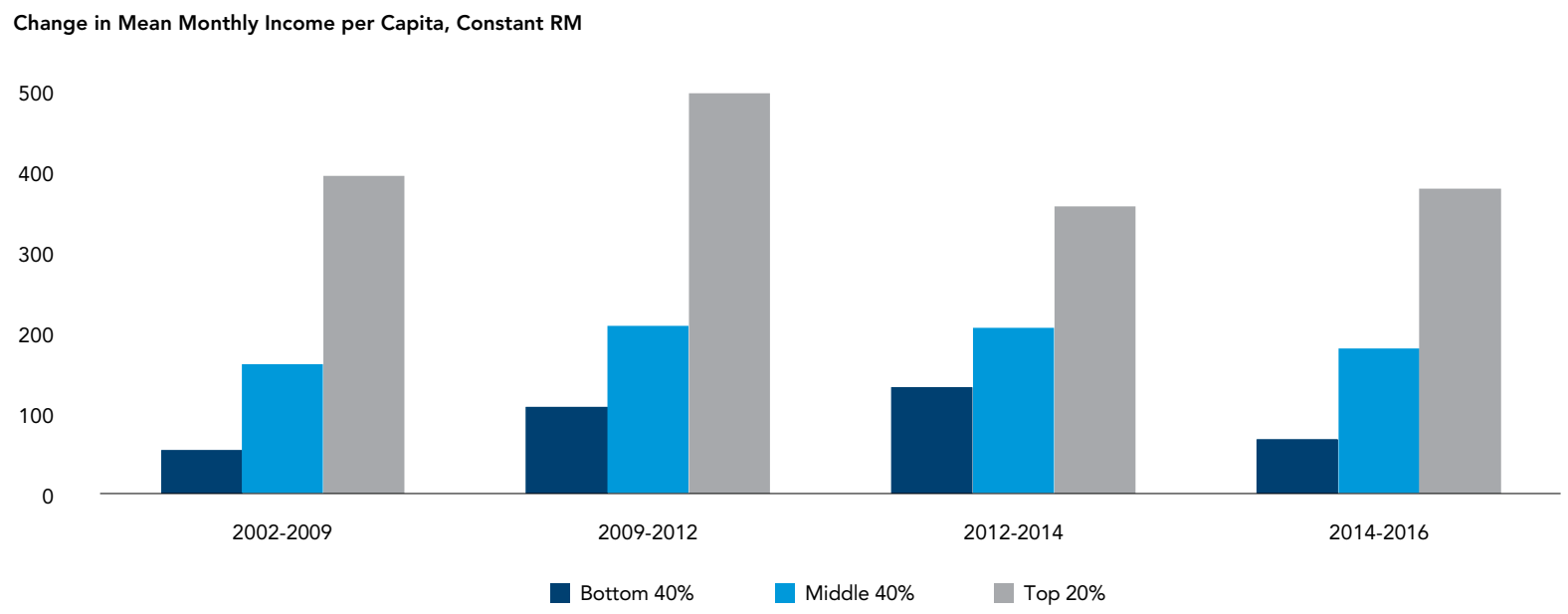

\section{Despite rising educational attainment, income growth among younger workers has been sluggish}

Employment earnings are the main source of income for those who are 20 to 59 years-old. The majority of Malaysians in this age range report at least some employment income-either from salaries and wages or from self-employment (see Table 7). ${ }^{21}$ For all age groups, men are more likely to have employment income than women, especially for those aged 30 or older. This gender disparity has been declining slightly over time as women's labor force participation has been increasing in recent years, while men's participation has remained relatively constant within each age cohort. It is also notable that the proportion of those 20-29 yearsold with employment income has been decreasing slightly over time, which is attributable in large part to later entry into the work force as more young Malaysians pursue tertiary education (see Table 8).

\footnotetext{
${ }^{21}$ The analysis presented here uses individual-level income data from the Household Income and Basic Amenities Survey. Employment income includes gross wages and salaries in cash and in kind, as well as allowances, bonuses, and employers' contributions to EPF and SOCSO. Self-employment income includes marketed output and own-consumption, net of production costs.
} 
TABLE 7

Percentage of Malaysians with employment income by year and gender

\begin{tabular}{|c|c|c|c|c|c|c|c|}
\hline Age group (years) & Gender & 2004 & 2007 & 2009 & 2012 & 2014 & 2016 \\
\hline \multirow[t]{2}{*}{$20-29$} & Men & 78.4 & 77.1 & 75.9 & 74.1 & 71.8 & 68.9 \\
\hline & Women & 55.2 & 53.7 & 53.4 & 53.0 & 51.1 & 50.6 \\
\hline \multirow[t]{2}{*}{$30-39$} & Men & 96.6 & 96.5 & 96.1 & 95.9 & 96.1 & 95.2 \\
\hline & Women & 49.7 & 51.0 & 52.2 & 58.8 & 56.8 & 59.2 \\
\hline \multirow[t]{2}{*}{$40-49$} & Men & 96.7 & 96.7 & 96.7 & 96.7 & 96.9 & 95.8 \\
\hline & Women & 44.4 & 44.1 & 43.8 & 50.0 & 48.1 & 51.5 \\
\hline \multirow[t]{2}{*}{$50-59$} & Men & 87.1 & 86.0 & 85.3 & 88.9 & 88.8 & 87.8 \\
\hline & Women & 29.8 & 29.9 & 31.5 & 35.0 & 33.4 & 35.1 \\
\hline \multirow[t]{2}{*}{$60-69$} & Men & 64.0 & 63.4 & 60.1 & 63.6 & 57.2 & 54.4 \\
\hline & Women & 18.2 & 19.5 & 17.4 & 18.7 & 14.9 & 14.9 \\
\hline
\end{tabular}

Source: World Bank staff calculations using Household Income and Basic Amenities Survey (DOSM)

TABLE 8

Percentage of those age 20 to 29 reporting their main activity as student by year and gender

\begin{tabular}{lccccccc} 
& $\mathbf{2 0 0 4}$ & $\mathbf{2 0 0 7}$ & $\mathbf{2 0 0 9}$ & $\mathbf{2 0 1 2}$ & $\mathbf{2 0 1 4}$ & $\mathbf{2 0 1 6}$ \\
\hline Men & 10.0 & 11.6 & 10.6 & 14.4 & 15.4 & 16.5 \\
\hline Women & 11.0 & 13.5 & 12.2 & 15.9 & 18.0 & 18.4 \\
\hline
\end{tabular}

Source: World Bank staff calculations using Household Income and Basic Amenities Survey (DOSM)

Younger workers in Malaysia experience slower income growth than their older counterparts, and the gap has widened in recent times. Incomes for all age groups have tended to grow faster than inflation, but the growth in employment earnings for younger workers has consistently lagged those of their older counterparts. Slower employment income growth is most pronounced among young men. For example, in 2004 median employment income among men aged 20-29 was 70 percent that of their counterparts aged $40-49$, and by 2016 that ratio had eroded to 58 percent (see Figure 52). Furthermore, between 2004 and 2016 the compound annual growth rates (CAGR) of median employment income for 20-29 year-old men and women were 2.1 and 2.6 percent, respectively, compared to 3.8 and 5.0 percent for those $40-49$ years old. The divergence in employment income by age groups accelerated after 2009 among both men and women. The relationship between age group and median employment income is somewhat weaker for women, which could reflect women above 30-years old who are more likely to work part-time to balance family and work commitments (see Figure 53).

Most of the employment income growth among those 20 to 29 years-old is associated with higher educational attainment. That is, to the extent that those in the youngest age cohort have experienced any employment income growth, it is largely because a higher proportion of them have tertiary education than was the case previously. Among those with post-secondary education, real growth in median employment income was substantial in the 40 to 59 year-old age brackets. Thus, their more rapid employment income growth stems from a combination of growing incomes over time for those with postsecondary education plus a higher percentage having post-secondary education (see Figure 54). In contrast, 


\section{FIGURE 52}

Younger male workers experience slower income growth and the gap has widened

Median Monthly Employment Income for Men, Constant RM

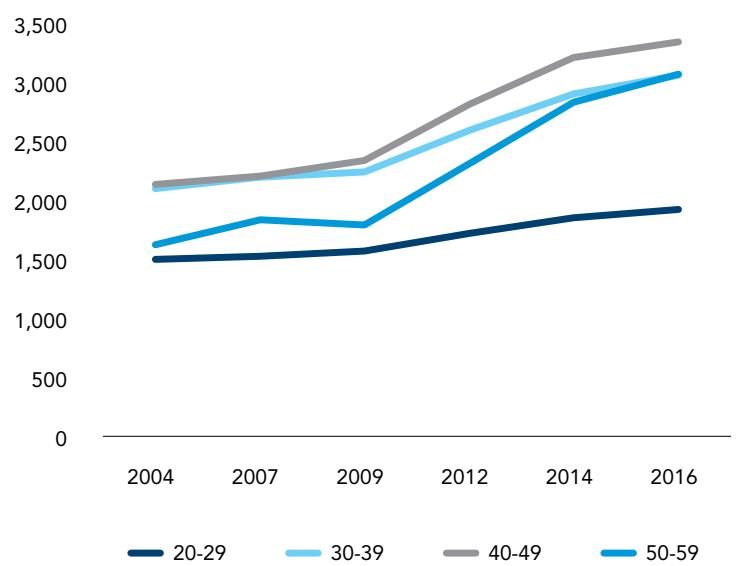

Source: World Bank staff calculations using Household Income and Basic Amenities Survey (DOSM)

20-29 year-olds only benefit from the second of those two effects, because employment income growth has been negligible among those with post-secondary education in this age group. ${ }^{22}$ The same is true to a lesser extent for 30-39 year-olds with post-secondary education, for whom growth in employment earnings has been relatively modest.

Among those with only secondary education, employment earnings are significantly lower for all age groups, with very modest growth over time. For those with only secondary education, the median income of the highest-paid age group (50 to 59 years-old) is RM2,612 as of 2016, which is about equal to that of the lowest paid age group with postsecondary education (see Figure 55). The increase in real employment earnings over time has been slower for those with less education, with compound annual growth rates ranging from 1.4 percent for 40-49 yearolds to 2.2 percent for 30-39 year-olds. Within each age group, median employment income for those who have completed post-secondary education is at least double that of those who have only completed secondary education. The median employment earning differences across age groups are much smaller for workers with only secondary education than they are for those with more education.

\section{FIGURE 53}

The relationship between age group and employment income is weaker for women

Median Monthly Employment Income for Women, Constant RM

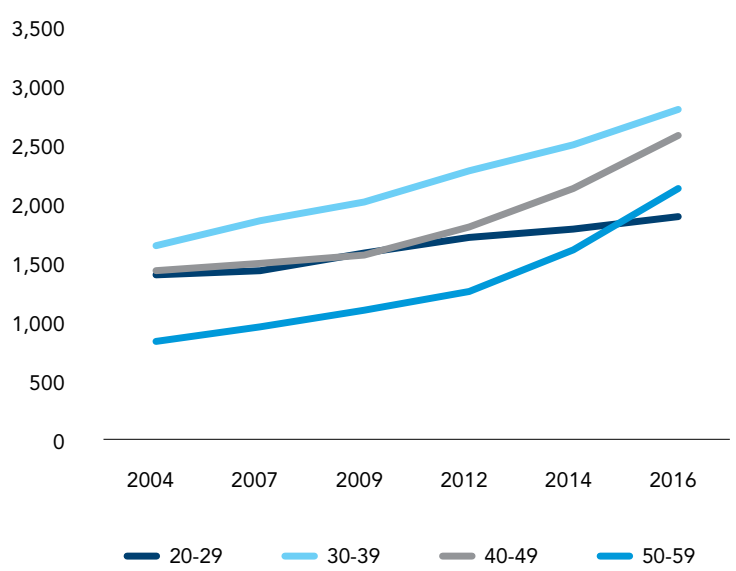

Source: World Bank staff calculations using Household Income and Basic Amenities Survey (DOSM)

Those who feel their incomes are not keeping up with the cost of living often opt to work more to try to make ends meet. This could mean a nonworking household member deciding to start working or a working household member taking on a second or even third job. In turn, the additional employment and possibly hours worked could impose additional costs, such as child care, transportation, or food away from home, as well as the stress of trying harder just to keep up (see Box 7). According to the HIS, the proportion of households with multiple people employed increased slightly from 2004 to 2012 and has stayed constant from 2012 to 2016, with 47 percent of households having a single earner and 38 percent having two members working (see Figure 56). Data from the Labor Force Survey (LFS) shows surprisingly little evidence of people working secondary jobs, in the range of only 1 to 2 percent of workers (see Figure 57). This is perhaps influenced by the framing of the question in the LFS, which uses the ILO standard reference period of the preceding seven days, which may therefore omit many secondary jobs that are occasional or infrequent. Qualitative research suggests that secondary jobs and multiple workers per household are more prevalent than indicated by quantitive survey data, and are increasing over time (see Box 7). 
FIGURE 54

Since 2009, real growth in income for 20-29 yearolds with post-secondary education was marginal

Median Monthly Employment Income with Post-Secondary Education, Constant RM

7,000

6,000

5,000

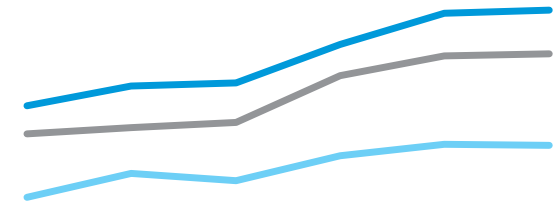

3,000

2,000

1,000

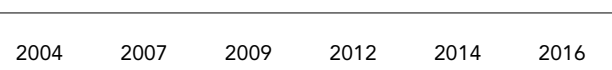

- 20-29 30-39 40-49 - 50-59

Source: World Bank staff calculations using Household Income and Basic Amenities Survey (DOSM)

FIGURE 56

The proportion of households with multiple people employed increased slightly from 2004 to 2012 then leveled off

Number of Employed People per Household, Percentage

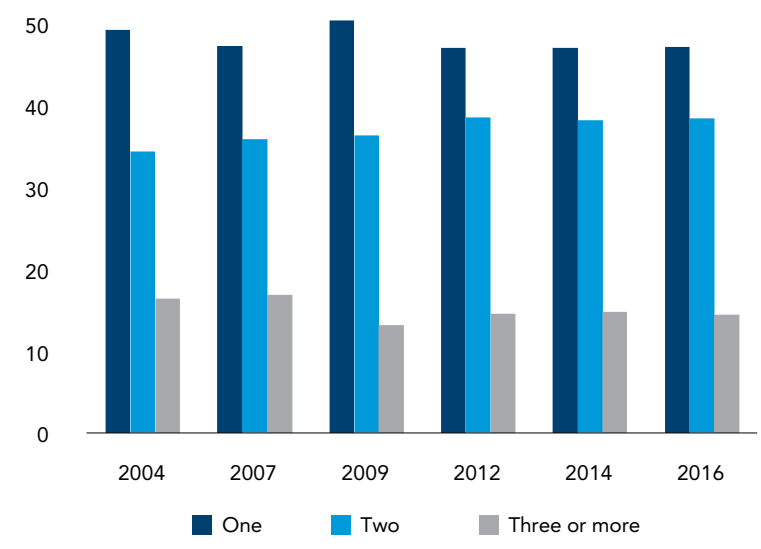

Source: World Bank staff calculations using Household Income and Basic Amenities Survey (DOSM)

\section{FIGURE 55}

Among those with only secondary education, income growth has been modest across all age groups

Median Monthly Employment Income with Secondary Education, Constant RM

7,000

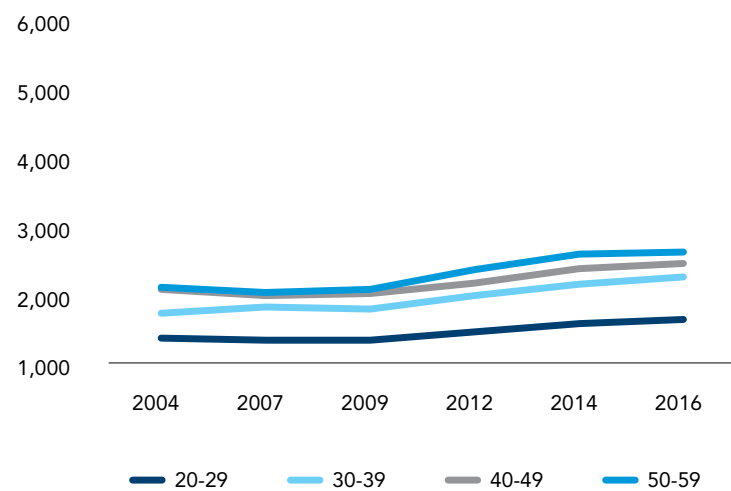

Source: World Bank staff calculations using Household Income and Basic Amenities Survey (DOSM)

FIGURE 57

The proportion of people recorded as working multiple jobs has been consistently low

Number of People Working a Second Job, Percentage

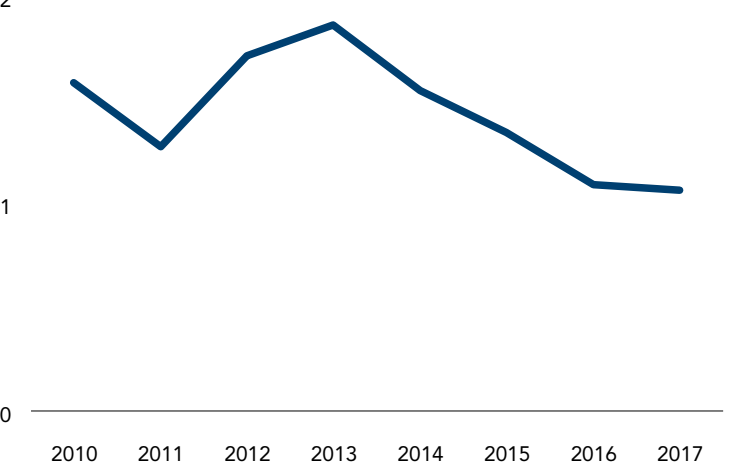

Source: World Bank staff calculations using Labor Force Survey (DOSM) 


\section{BOX 7}

\section{Getting by with dual income earners and multiple jobs}

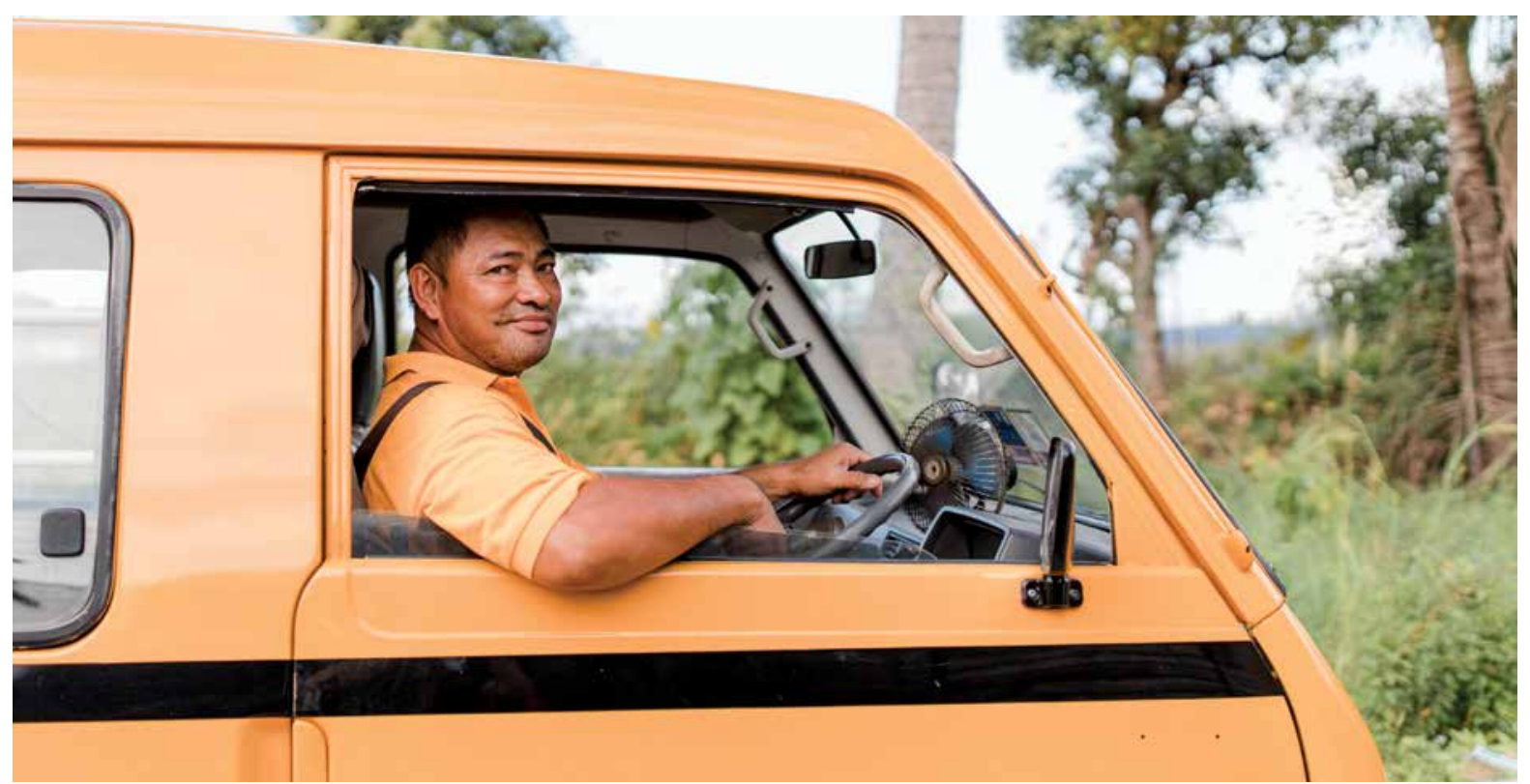

Many low-income Malaysians are only able to make ends meet through multiple jobs. The need for dual incomes and holding down multiple jobs per earner was discussed in nearly half of all focus groups conducted in the Klang Valley and Terengganu as part of the joint World Bank-University of Malaya qualitative study on living standards.

"Most of the people in my salary range actually work two jobs. Having two jobs makes it more secure. I cannot go up. I cannot go down. Yeah, I am stuck here. I am trapped."

[Klang Valley, Chinese, M40]

"Doing one job is no longer sufficient financially. Even 2-3 jobs can leave a question mark about whether you have enough to meet basic needs." [Klang Valley, Indian, B20]

There is no disposable income. Every penny we earn, we know how it will be spent. That is why a lot of us housewives are taking on miscellaneous jobs to support our husbands with extra income.

[Klang Valley, Bumiputera, B21-B40]
A young, unmarried engineer in Terengganu explained how, after paying off his monthly expenses, he was left with no savings and had to resort to a second job. Moreover, he did not foresee a future in the same company as the yearly increment was negligible.

"My salary is not that high. After EPF contribution, I earn RM2,300. My car loan is RM600. I need my car for my job. I pay RM300 for PTPTN loan and RM100 for medical insurance. After deducting all these plus some other expenses, I am left with RM800. I have no savings. I am single and live with my parents. I started a second job. I teach electronics, I sell electronic items. Without this second job, I would have no disposable income. Even though I work in a good company, my yearly increment is only RM50. If I continue here, I won't go far." [Terengganu, Bumiputera, B21-B40] 


\section{Borrowing provides temporary income support to lower-income households}

Recently, the concept of a "living wage", which is the income level needed to meet a reasonable standard of living - beyond what is needed for subsistence ${ }^{23}$ - has been introduced in Malaysia. BNM (2018a) estimates the living wage in Kuala Lumpur, as of 2016, to be RM2,700 for a single adult, RM4,500 for a couple without a child and RM6,500 for a couple with two children. The Belanjawanku report by EPF and SWRC (2019) is similar in spirit to BNM's living wage analysis, providing reference budgets for different types of households and life-cycle stages, including details about specific living cost categories and benchmarks for retirees. The Belanjawanku report suggests wage levels in Klang Valley that are close to BNM's living wage: RM2,490 for a single adult with a car, RM4,420 for a couple without a child, and RM6,620 for a couple with two children.

\section{There is a strong correlation between level of education and households earning less than the living wage.}

Approximately 27 percent of households in Kuala Lumpur earn less than BNM's estimated living wage, ${ }^{24}$ thus limiting their ability to have a meaningful and dignified life in the society. There is a strong correlation between level of education and households earning less than the living wage. Findings by BNM also show that 73 percent of those earning below the living wage have either secondary, primary, or no education. In contrast, 72 percent of those earning above the living wage have completed tertiary education. ${ }^{25}$ Furthermore, those involved in low- and middle-skilled jobs are more likely to earn below the living wage, although above the minimum wage. The same applies to married couples with or without children. According to BNM, there are two types of consumption expenditure: necessity and discretionary spending. ${ }^{26}$ Necessity items include basic goods required to sustain life, such as medical- and education-related consumption, whereas discretionary consumption comprises "expenditure to support lifestyle choices," including spending on durable goods, weddings and festive seasons. Hence, individuals and households who don't earn as much as the living wage need to either reduce expenditures or increase incomes through additional jobs, borrowing, and investment.

Borrowing provides temporary relief for households to compensate for inadequate income, particularly in the short-term. According to the Agensi Kaunseling dan Pengurusan Kredit (AKPK), ${ }^{27} 28$ percent of the 3,540 randomly-selected Malaysian working adults surveyed in 2018 had to borrow from family and friends to buy essential goods. While borrowing provides opportunities for shifting consumption and making investments, the debt obligation also limits discretionary spending as a larger portion of household income is already pre-committed for monthly loan repayment. Higher levels of household debt relative to a few years ago may be seen as a positive development that enables households to use credit to invest in a home or otherwise smooth consumption over the life cycle. However, it also makes it easier for a household to live beyond its means, or to perceive that living costs are escalating faster, than they are because the household has less discretionary income after factoring in obligatory loan repayments.

\footnotetext{
${ }^{23}$ Basic needs such as food, clothing, and shelter. Source: BNM (2018a).

${ }^{24}$ BNM (2018a)

25 DOSM (2019), "Salaries and Wages Survey Report 2018".

${ }^{26}$ BNM (2018a).

${ }^{27}$ Credit Counseling and Debt Management Agency.
} 


\section{Beyond housing and car loans, lower-income borrowers tend to use personal finance loans and credit cards to raise living standards}

Lower-income households and certain segments of the population have a heavy debt load and face a high debt service ratio (DSR). Recent studies by BNM and others have highlighted the heavy debt load carried by borrowers earning less than RM5,000 per month, with more than 50 percent of the debt channeled for purchases of motor vehicles and personal financing, ${ }^{28}$ as opposed to borrowing to build longterm wealth (see Box 8). Similarly, a large share of debt (45 percent) among civil servants are personal financing and motor vehicle loans (BNM, 2018c). The DSR remains high for borrowers with monthly incomes less than RM 3,000. Approximately 40 percent of lower-income borrowers have DSRs above 40 percent, which leaves them with little discretionary income and saving capacity (see Figure 58). ${ }^{29}$ Comparing the DSRs between the average borrowers and civil servants, the latter faces a significantly higher DSR levels, with over 50 percent of monthly income used for debt repayment, which is 1.6 times the DSR among average borrowers in the same income group (see Figure 59). ${ }^{30}$

\section{FIGURE 58}

Lower-income borrowers have high DSRs leaving little room for other expenditures or savings

Share of Borrowers, Percentage

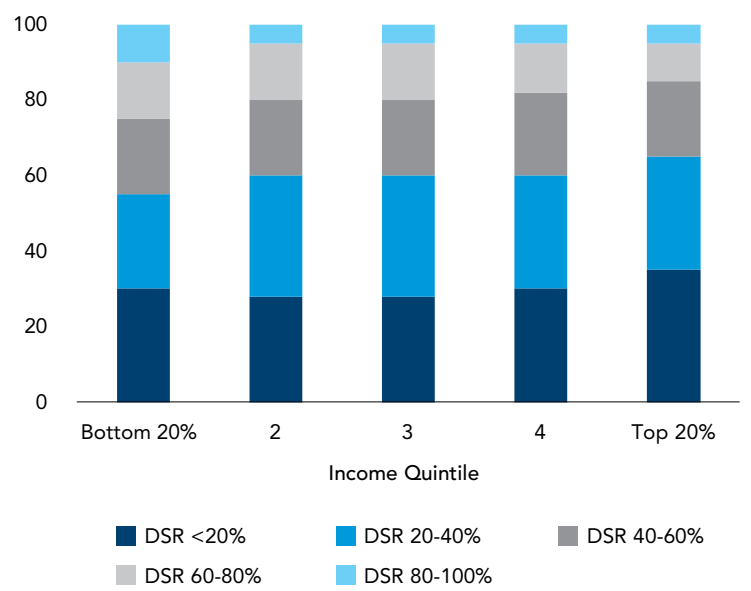

In addition to housing loans, nearly every household, including a majority of lower-income households, have car loans (see Figure 60). Housing has always been a large part of household debt and is sometimes perceived as a 'good debt' as it allows homeowners to enjoy returns on investment and stable wealth accumulation over time. Notwithstanding this development, car loans remain one of the most common forms of debt across all age groups, with 45-65 percent of respondents surveyed by AKPK having car loans (see Figure 61). Unlike housing loans, motor vehicle loans increase household liabilities without increasing the household's long-term assets, and monthly payments may comprise up to one-third of income for lowerincome borrowers. High rates of vehicle ownership may also suggest inadequacies in the public transportation system, such that Malaysians do not want to rely on public transit for all of their transportation needs. With increasing motor vehicle ownership and car loans, it costs households at least five times more ${ }^{31}$ than taking public transportation for a daily commute. ${ }^{32}$

\section{FIGURE 59}

Civil servants also tend to have significantly higher levels of DSR

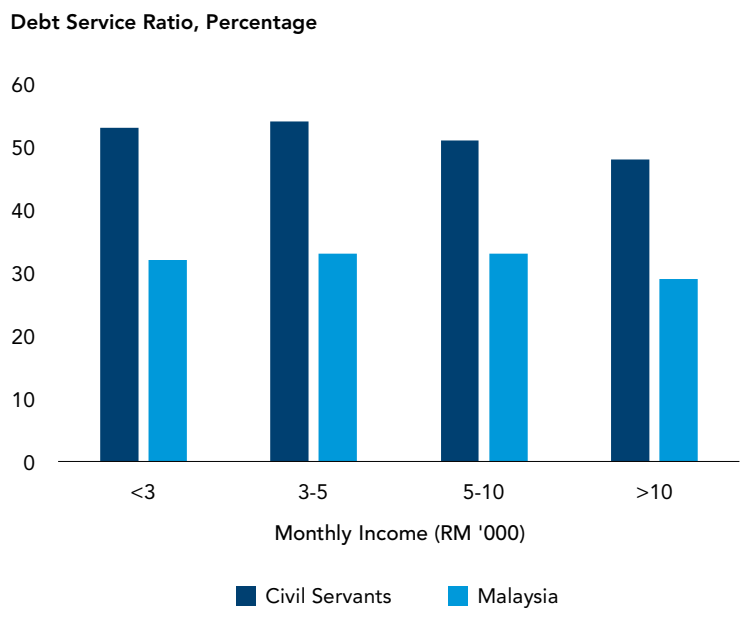

Source: BNM

${ }^{31}$ Including monthly car loan instalments, insurance, fuel, tolls, and other maintenance fees. Source: World Bank staff calculations.

32 Referring to the RapidKL RM100 monthly unlimited pass for trains and buses. 


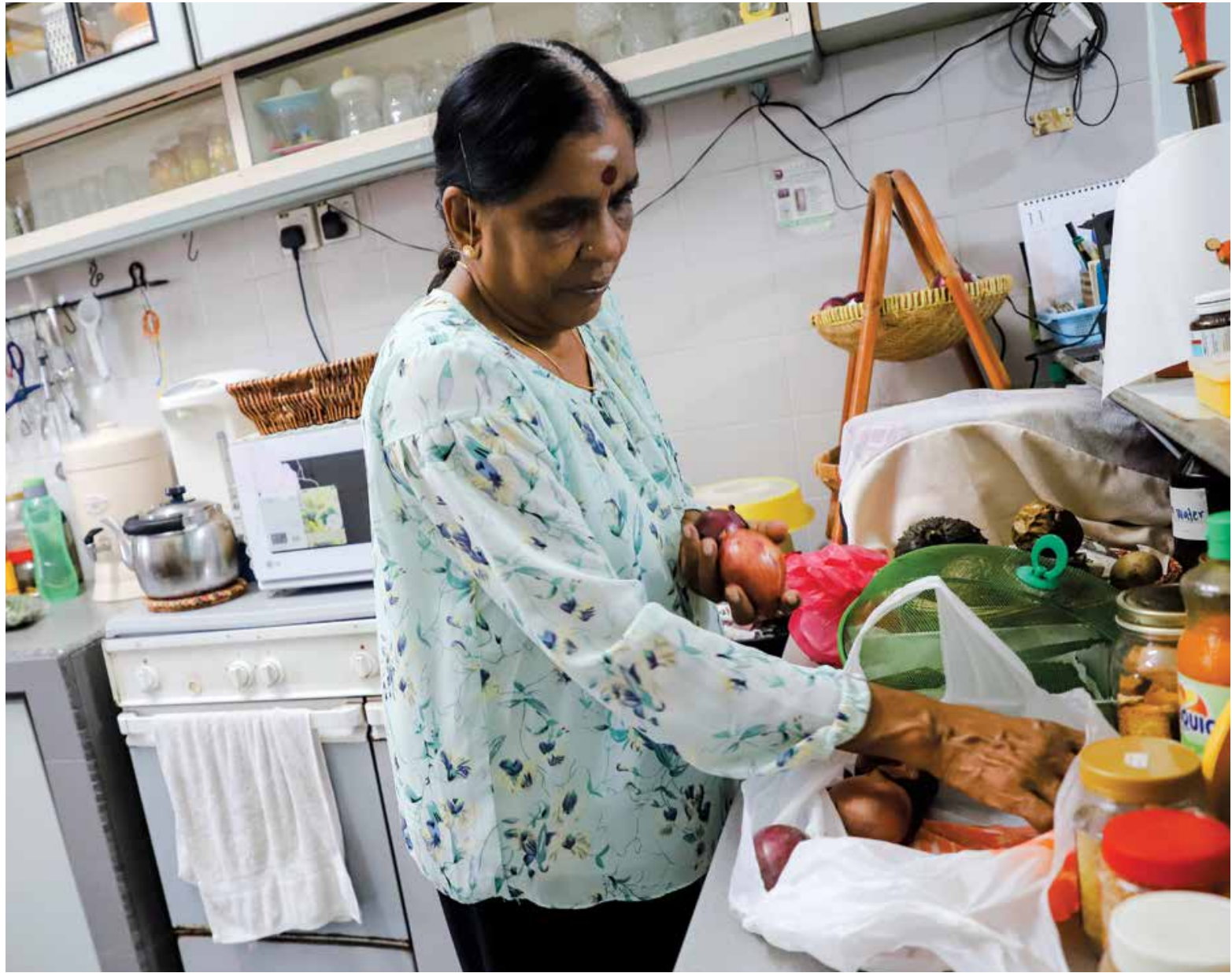

\section{Debt as a double-edged sword}

In the joint World Bank-University of Malaya qualitative study, lower-income households described their monthly struggle to service loans. In a common theme across regions and ethnic groups, participants from the B20 and B21-B40 income groups found it difficult to survive on their current incomes, given their commitments on housing, car, and other types of loans. This is consistent with BNM's data which showed high DSRs among lower-income borrowers, resulting in limitations for household savings and consumption on other items.

"At the end of every month, I feel like going insane because always I feel I do not have enough to settle all payments. I need to pay house mortgage, car loan, children's education and needs, utility bills...water, electricity...after settling all these bills, the balance is almost zero. Then the wait starts for the following month's salary for the same purpose."

[Klang Valley, Indian, B20]

"Definitely you need a loan for everything. For house, for car. For professional people, it may be easy to pay back. But my job is unstable. It is hard for me."

[Klang Valley, Chinese, B20]

"By the 20th of the month, we have to scrape the bottom of the barrel while waiting for our pay for the next month."

[Terengganu, Bumiputera, B21-B40] 


\section{FIGURE 60}

Nearly every household, including a majority of lower-income households, owns a car

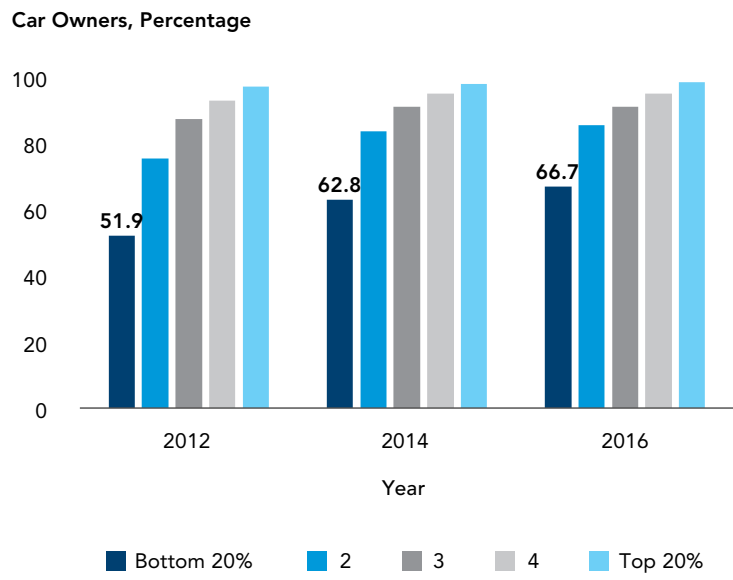

Source: World Bank staff calculations based on DOSM data

Households with income below the living wage also tend to take on personal financing loans for consumption. Personal financing is widely used to keep up with "lifestyle" choices, which are considered discretionary consumption ${ }^{33}$ that provides an improvement in living standards beyond the basic items needed for survival. In some ways, lifestyle choices would be included in the living wage, enabling individuals to participate in meaningful social activities and events such as festive seasons. Among AKPK clients earning below RM5,000, 32 percent of the personal loans were spent on discretionary items, twice as much as was spent on necessity items (see Figure 62).

Apart from personal financing, households find an alternative to maintain higher standard of living through credit cards. It is increasingly easy to get credit cards, and households are increasingly turning to credit cards to help make ends meet, and frequently encountering challeges of overspending and poor debt management. While an increasing share of household credit card debt could suggest households using debt to improve their living standards in the short-term, it could also indicate that people are spending beyond what they can afford. Even with an annual income of RM24,000, individuals can get bank approvals for a credit card. ${ }^{34}$ It is common for Malaysians to have

\section{FIGURE 61}

Ownership of car loans cuts across all age groups

Loan Ownership, Percentage

80

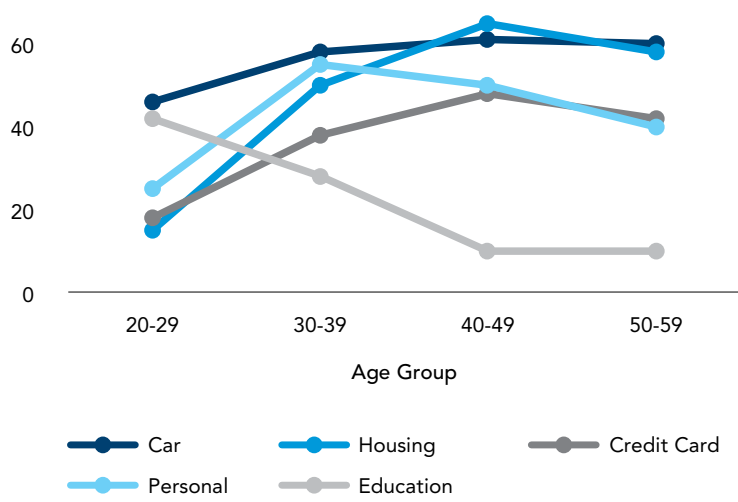

Source: AKPK

at least one credit card, if not multiple cards from various banks ${ }^{35}$ and this creates more opportunities for individuals and households to spend beyond what they earn.

High rates of bankruptcy because of borrowing for consumption rather than for wealth accumulation are an increasing concern, especially among younger borrowers with limited financial knowledge and literacy. Defaults on motor vehicle and personal financing loans constitute almost half of the total bankruptcy cases (49 percent in 2018), while the number of bankrupt borrowers with either personal financing or credit card debts has increased since 2013 (see Figure 63). The number of bankruptcy cases involving personal financing and credit card debts has grown by 104 percent and 43 percent, respectively, in 2018 compared to 2012. Moreover, there is increasing concern for bankruptcy among the 25-34 year-olds (see Figure 64). Approximately 60 percent of the bankrupt borrowers were millennials between the ages of 25 and 44 years old. Therefore, millennials' spending beyond their income can be detrimental and lasting if they continue to lack financial knowledge and money management skills (see Box 9 on millennials living beyond their means).

${ }^{33}$ BNM (2018b) defines discretionary consumption as "expenditure to support lifestyle choices, which include the purchase of durable goods and expenses for weddings and festive seasons" (p. 16).

${ }^{34}$ CompareHero.my (2019).

${ }^{35}$ A survey by RinggitPlus (2019) found that 58 percent of respondents have one to three credit cards and 12 percent have four or more. 
FIGURE 62

A large share of personal financing loans among AKPK clients is used for discretionary spending

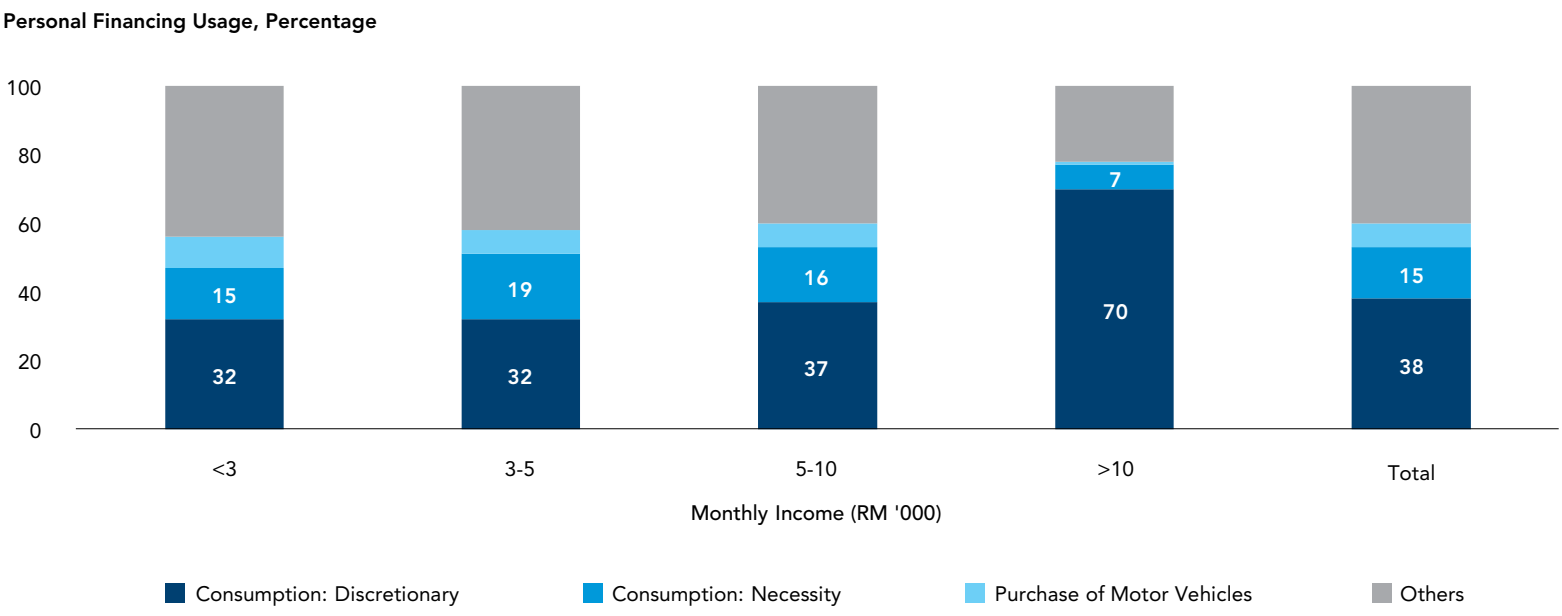

Source: BNM

FIGURE 63

There has been an increase in bankruptcy cases due to personal financing and credit cards...

Number of Bankruptcy Cases, Thousands

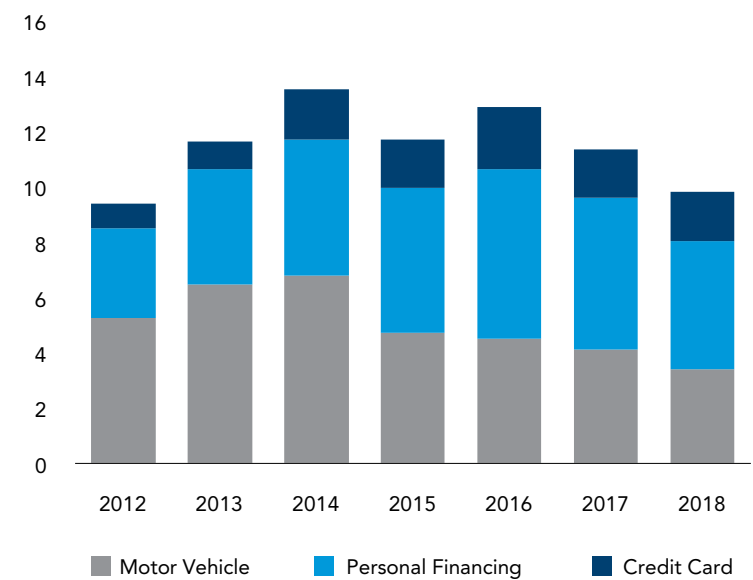

Source: Malaysian Department of Insolvency
FIGURE 64

...with the number of bankruptcies being the highest among working adult population

Number of Bankruptcy Cases, Thousands

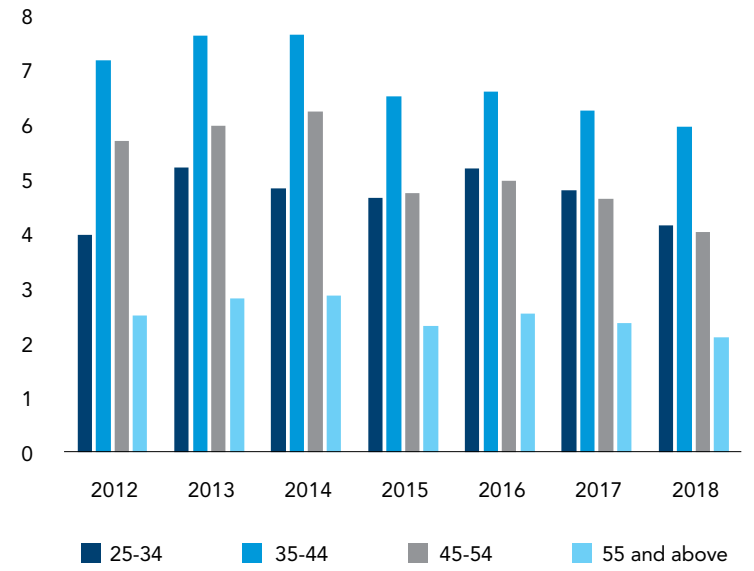

Source: Malaysian Department of Insolvency 


\section{Millennials' consumption behavior and financial savvy}

\begin{abstract}
Millennials have been criticized for "living beyond their means" in the Finance Matters: Understanding Gen $Y$ report by the Asian Institute of Finance. Milennials, or Gen Ys, form a majority of Malaysians who spend well beyond their means, due to "impulsebuying behavior, easy access to personal loans and credit card financing, the want for instant gratification, and seamless online purchasing". ${ }^{36}$ About 40 percent of millennials admitted to spending more than they can afford, while 70 percent expressed dissatisfaction with their current income. ${ }^{37}$ Credit cards are an increasing source of borrowing, which allows for prolonged outstanding balances - and thus rapid build-up of debt - since the card holder is only required to settle the minimum monthly payment after use (BNM, 2018c). Are these short-lived financial behaviors, or could they lead to serious ramifications such as bankruptcy?
\end{abstract}

\section{About 40 percent of millennials report spending more than they can afford, and 70 percent express dissatisfaction with their current income.}

\footnotetext{
Most of the spending by millennials is on necessity items such as food and utilities. Millennials, also known as Gen Y, are those born between 1981 and 1996, which means they are between the ages 23 and 38 today. ${ }^{38}$ Different age cohorts spend differently, and
}

\begin{abstract}
the same is true within each age cohort. More American millennials are spending on necessity items - groceries, utilities, and healthcare - than on discretionary items such as traveling and dining out. ${ }^{39}$ In Malaysia, those between ages 25 and 44 in the Household Expenditure Survey ${ }^{40}$ have been spending similar proportions on food at home and food away from home. Up to 40 percent of consumption was spent on food expenditures among the Gen $Y$ household heads, including food at home and food away from home ${ }^{41}$ in 2016 (see Figure 65).
\end{abstract}

\begin{abstract}
Millennials, including in Malaysia, lack financial knowledge and capacity to help manage their financial well-being. Across 1,011 respondents to a 2015 survey by AIF, Gen Ys between 20-33 years old said they lack confidence in financial knowledge and ability, 14 percent rated themselves as having poor or very poor financial knowledge and 58 percent said they have average financial knowledge. Furthermore, in 2017, the Global Finance Literacy Excellence Centre found that only 36 percent of Malaysians between 15-34 years old were financially literate compared to 66 percent in Singapore and 51 percent in Myanmar. ${ }^{42}$ About 20 percent of millennials do not save, citing indebtedness, high cost of living and spending on lifestyle choices as reasons why they do not save. ${ }^{43}$ Among the millennials who do save, 43 percent do not invest their money at all, while 16 percent invest once every one or two years (Free Malaysia Today, 2019).
\end{abstract}

${ }^{38}$ Dimock, M. (2019) "Defining generations: Where Millennials end and Generation Z begins", Washington, DC: Pew Research Center.

${ }^{39}$ Based on a Gallup (2016) study on "How Millennials Want to Work and Live".

${ }^{40}$ DOSM (various years).

${ }^{41}$ Referring to "restaurants and hotels" in the Household Expenditure Survey, indicating discretionary consumption.

42 Khidhir, S. (2019), "Malaysia's millennials need help."

${ }^{43}$ Based on RinggitPlus' 2019 survey, 69 percent of the respondents were 20-39 and the rest 40-60 year-olds. 21 percent of the respondents generally don't save, either because they are paying off debts ( 34 percent), essential expenses are too high ( 29 percent), have no balance at the end of the month ( 25 percent), or spend too much on discretionary items (12 percent). 


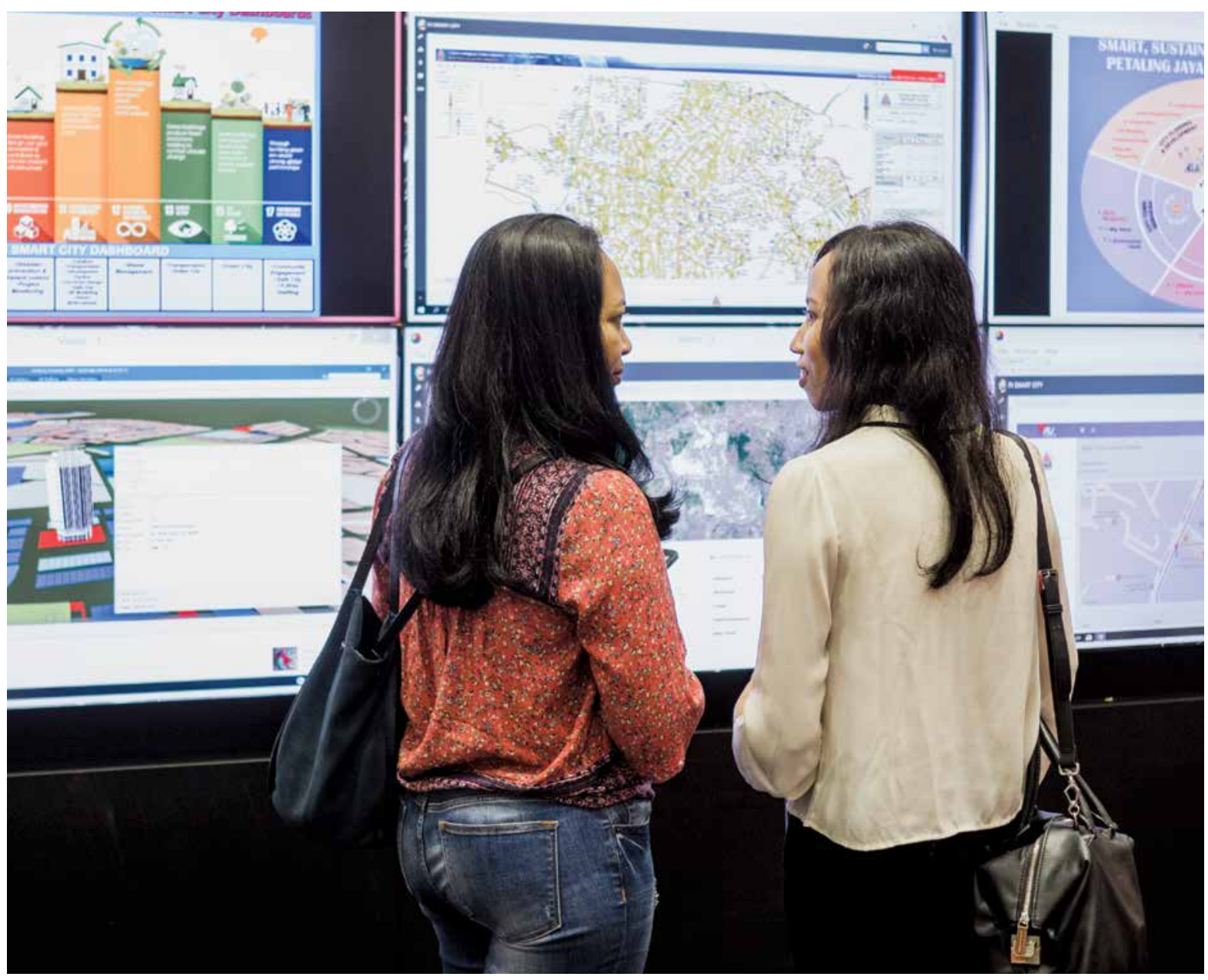

FIGURE 65

Millennials spend mostly on food, whether necessity or discretionary items

Share of Spending, Percentage

Age 25-34

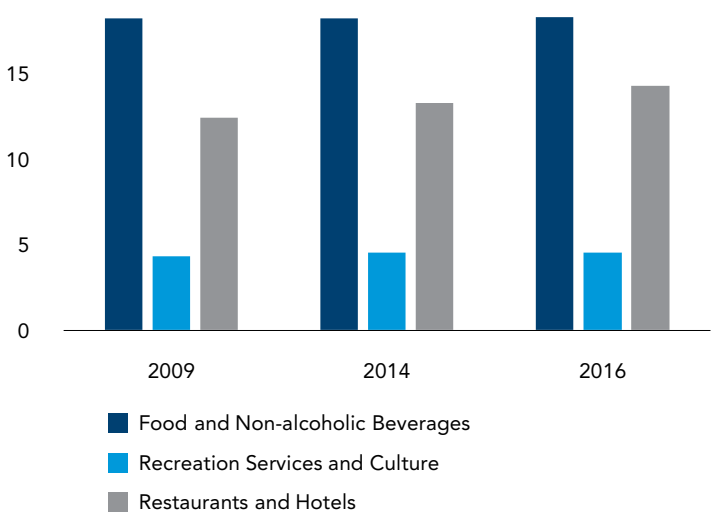

Age 35-44

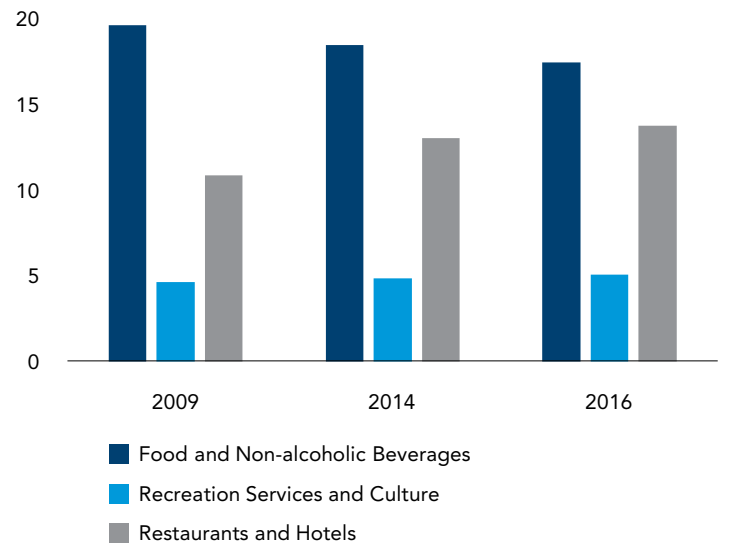

Source: World Bank staff calculations based on DOSM data 


\section{Malaysian households, particularly lower- income households, do not have adequate financial savings}

\begin{abstract}
A large share of working adults, especially those earning below RM4,000, feel under pressure with their current financial position. Based on the AKPK survey of financial behavior and well-being, ${ }^{44}$ in terms of spending, savings, and debt management, almost onethird of the respondents earning below RM4,000 and one-fifth of those earning RM4,000-RM8,000 had low scores for their financial behavior. Consequently, they experience lower scores for financial well-being, with 58 percent of the lower-income group (below RM4,000) and 36 percent of the middle-income group (RM4,000$\mathrm{RM} 8,000)$ feeling under pressure or needing attention given their financial position.
\end{abstract}

\section{9 percent of EPF members agree that their EPF savings are insufficient for retirement.}

Financial pressures are being felt by most working adults regardless of age group. Financial behavior scores are similar across all age groups, though the older cohorts, 40-49 and 50-59 year-olds, have slightly better ratings in "good" and "exemplary" financial behavior. The financial well-being of younger working adults, 2029 and 30-39 year-olds, tends to be poorer than older age cohorts, with 22 percent and 25 percent feeling under pressure given their financial position, compared to 19 percent and 12 percent feeling under pressure among the 40-49 and 50-59 year-olds. ${ }^{45}$ Regardless of age, the majority of working adults with reasonable financial behaviors scores still feel under pressure financially. In the World Bank-University of Malaya study on living standards, a participant in the M40 income group living in Petaling District explained how he has to count sen in order to provide a comfortable life for his family.

\begin{abstract}
"Both my wife and I are working while my children are in a private pre-school. I want to provide a comfortable life for my family. I work part time as a barber. Yet, I have to think twice about getting a house. I have no savings. Sometimes, I think twice when I give RM100 to my parents. I have to count my money before fueling my car. I struggle to pay for domestic household expenses. I have second thoughts when we are out and try to choose the cheaper mamak stand."
\end{abstract}

[Klang Valley, Bumiputera, M40]

Individuals' current savings with the Employee Provident Fund (EPF) indicate that most EPF members do not have sufficient savings for retirement. Although more than 89 percent of EPF members agree that their EPF savings are insufficient for retirement, only 38 percent have started planning for retirement. ${ }^{46}$ Moreover, 60 percent of Malaysian adults are not covered by the EPF. ${ }^{47}$ The reasons for low savings in EPF accounts are various, but include the low base of starting salaries (on average), and the slow growth of salary during the years of active contribution; 'leakages' before the official withdrawal age for housing, health or education expenditures allowed prior to retirement (which is a common design for provident funds); and the 'density of contributions', which falls below 100 percent for many workers meaning that they are not able to contribute every year. The EPF's Belanjawanku report estimated that an elderly couple living in Klang Valley needs approximately RM3,090 for monthly living expenses.

\section{Malaysia's household savings rate is low compared to OECD countries and other comparators. The gross household savings rate in Malaysia is 1.5 percent of adjusted disposable income ${ }^{48}$ compared to 7.8 percent in the United States and 9.6 percent in Chile in 2015 (see Figure 66). ${ }^{49}$ In fact, 37 percent of households with incomes below RM2,000 said they do not save at all. ${ }^{50}$ About half of Malaysian households do not have}

\footnotetext{
${ }^{44}$ AKPK (2018) surveyed the financial behavior and financial well-being of 3,540 working adults across Malaysia. Financial behavior refers to three key areas in money management-(1) spending, (2) savings, retirement, and investment, and (3) debt management-while financial well-being measures the ability to lead a meaningful, content, and sustainable life without constant financial worries.

${ }^{45}$ AKPK (2018).

${ }^{46}$ RinggitPlus (2019), "Malaysian Financial Literacy Survey 2019".

${ }^{47}$ Financial Education Network (2019), "National Strategy for Financial Literacy 2019-2023".

${ }^{48}$ DOSM (2015), "Distribution \& Use of Income Accounts and Capital Account".
} 


\section{FIGURE 66 \\ Malaysia has one of the lowest rates of household savings}

Gross Household Savings, Percentage

14
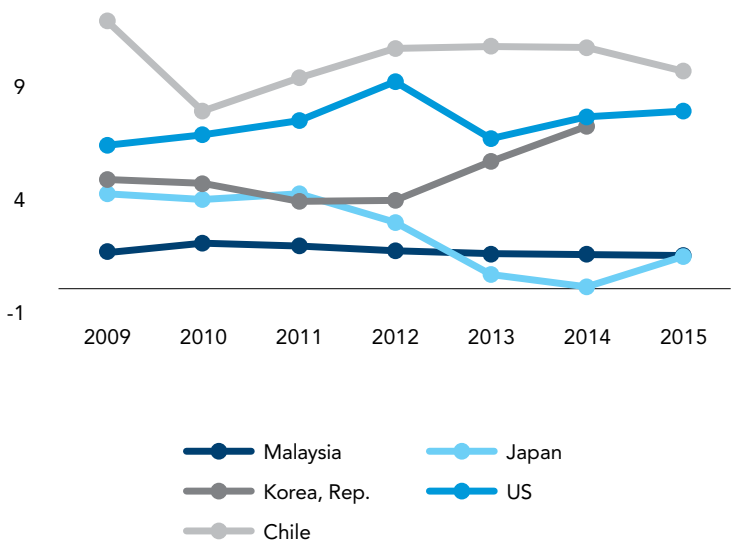

Source: KRI, OECD

sufficient savings to cope with unforseen financial shocks such as emergencies, medical bills or job loss (see Figure 67). Among the millennials who save part of their income, approximately 60 percent have savings that amount to three months' income or less (Vase.ai, 2019). ${ }^{51}$

The current state of financial well-being among Malaysia's households underscores the importance of financial literacy across income levels and age groups. If households lack financial knowledge and planning, it will be hard for them to sustain their living standards after retirement. ${ }^{52}$ For the 40 year-olds and older, financial knowledge and the ability to accumulate savings is pertinent to avoid having no choice but to work beyond retirement age because of financial pressure. Retirees also need financial education to ensure sustainable use of their savings over time, preventing them from using up the money few years after retirement (Jomo, 2017). Therefore, financial literacy is required for all income groups and at all stages of life. EPF has begun offering financial planning workshops for its members, including education on extending the years of contribution, retiring later,

\section{FIGURE 67}

\section{About half of Malaysian working adults lacks financial resilience, especially the younger generation}

Number of Individuals by Age Group, Percentage

100

50
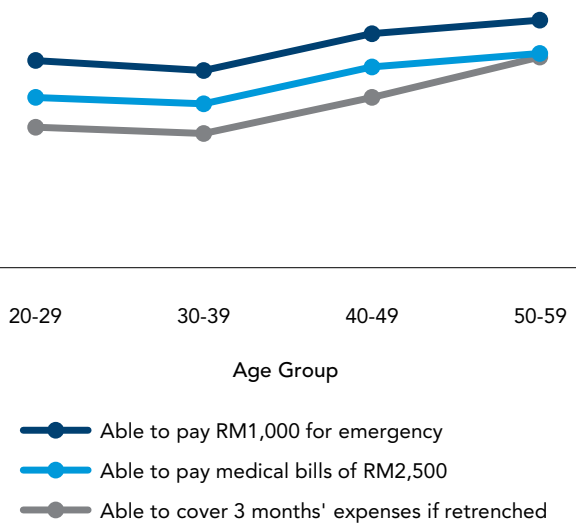

Source: AKPK

and the potential to increase total pension through an annuity option. The recently launched National Strategy for Financial Literacy 2019-2023 formulated by the Financial Education Network (FEN) ${ }^{53}$ has expanded public and private financial literacy initiatives which have been previously done at a smaller scale. ${ }^{54}$ It is hoped that the National Strategy will help raise awareness among citizens on their rights and responsibilities in personal and household financial management and to be accountable for their financial decisions. It is also worth noting that financial education is now provided (at varying levels) by all financial institutions in Malaysia per consumer protection regulations by Bank Negara Malaysia and Securities Commission Malaysia and aspects of the financial education has been integrated into the formal curriculum for K-12 by the Ministry of Education.

\footnotetext{
${ }^{49} \mathrm{KRI}(2016)$.

${ }^{50}$ RinggitPlus, "Malaysian Financial Literacy Survey 2019".

51 Vase.ai (2019) survey which includes 1,525 millennials.

${ }^{52}$ Other reasons for low pension savings include (i) low base salaries and growth of salaries in the early years of pension contribution, (ii) withdrawals for retirement age for housing, health or education expenditures, and (iii) employees not making the full contributions in some years, which is permitted by EPF.

${ }^{53}$ The FEN comprises Bank Negara Malaysia, Securities Commission Malaysia, Ministry of Education, Employees Provident Fund, Perbadanan Insurans Deposit Malaysia, Permodalan Nasional Berhad, and Agensi Kaunseling dan Pengurusan Kredit.

${ }^{54}$ See Appendix for a summary of financial literacy initiatives in Malaysia.
} 


\section{The availability of affordable housing in Malaysia has deteriorated over the years}

\begin{abstract}
Housing is a basic need and is one of the largest household expenditures. The amount a household must pay for housing directly impacts its ability to pay for other necessities such as food, education, transportation and health. If the cost of housing is too high as compared to a household's income, the household may have no choice but to compromise other expenditures to remain sheltered. Households that are unable to afford a safe, adequate and well-located home may have to find alternate accommodation that compromises their health or well-being or forces long commutes to access livelihoods and basic services. Owning a home also constitutes one of the primary vehicles for wealth accumulation, especially if the value of the home appreciates over time. As of 2016, Malaysia's homeownership rate was 76.3 percent (including owner-occupied homes with mortgages), higher than many OECD and high-income countries (Ismail et al., 2019).
\end{abstract}

Various studies ${ }^{55}$ using the price-income ratio (PIR) have concluded that housing affordability in Malaysia has deteriorated, with varying degrees across states. Also known as the median multiple index, the ratio compares the median house price to median household income. A widely-used categorization developed by Demographia (2019) categorizes housing as "moderately unaffordable" (PIR of 3.1 to 4.0), "seriously unaffordable" (PIR of 4.1 to 5.0) or "severely unaffordable" (PIR of 5.1 higher). By this classification, the median multiple for Malaysia has exceeded the 3.0 threshold for affordability since at least 2002, and deteriorating sharply from 2012 to 2014, when the median multiple increased from 4.0 to 5.1 (see Figure 68 As of 2016, Malaysia's median multiple index stood at 5.0, categorizing housing as "seriously unaffordable" in Malaysia overall, and "severely unaffordable" for several states such as Penang, Kelantan, Negeri Sembilan and Sabah, as illustrated in Figure 69.

The deterioration of housing affordability, based on the PIR methodology, can be attributed to several factors, including urbanization and unresponsive supply. ${ }^{56}$ Firstly, rural to urban migration and changes in the country's main industries have altered the country's demographics and increased housing demand, particularly in urban areas. ${ }^{57}$ Secondly, until

\section{FIGURE 68}

By one measure, housing in Malaysia has been classified as "unaffordable" since 2002

Price-to-income Ratio

6.0

5.5

5.0

4.5

4.0

3.5

3.0

2002

2004

2007

2009

2012

2014

2016

\footnotetext{
${ }^{55}$ See, for example, Ismail et al. (2019) and BNM (2017b).

${ }^{56}$ See World Bank (2015) for a broader discussion of the urbanization challenges that Malaysia faces, including the relative lack of economic density and urban sprawl of key cities, resulting in urban households in Malaysia spending a higher share of their income on transport relative to in key comparator economies.

57 From 1990 to 2019, the number of households has more than doubled, increasing from 3.6 million to 8 million (Department of Statistics Malaysia, 2019).
} 
FIGURE 69

Housing affordability varies across states, with four states categorized as "severely unaffordable"

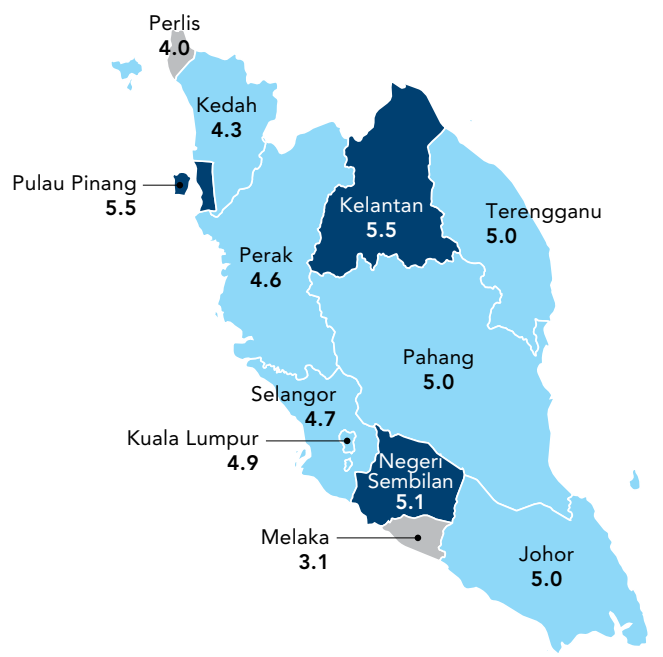

Severely Unaffordable

Seriously Unaffordable

Moderately Unaffordable

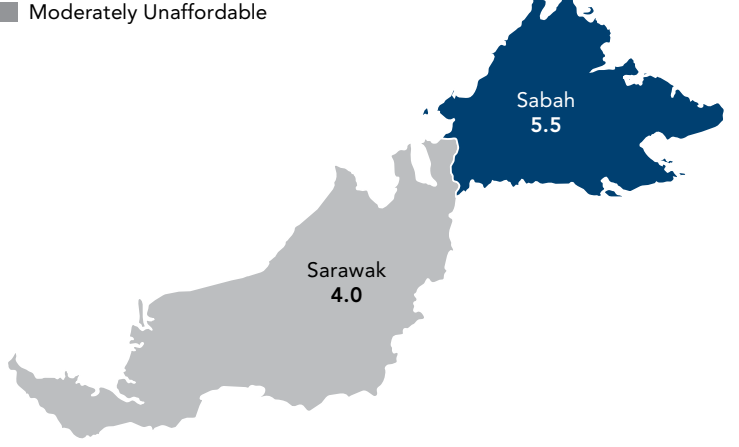

Source: Ismail et al. (2019)

recent years, housing supply was not responsive to this increase in demand, exacerbating increases in housing prices, especially in economic centers such as Selangor. Furthermore, new housing built since 2008 has been dominated by properties priced at RM250,000 and above. As a result, newly launched housing units priced below RM200,000 made up less than 20 percent of the total units in 2016 (see Figure 70). Finally, wages have not increased as rapidly as housing costs have. While the cumulative salaries and wages increased by 59 percent from 2010 to 2018, the cumulative house prices increased by 87 percent. ${ }^{58}$

\section{FIGURE 70}

Only 18 percent of newly launched units in 2016 were priced below RM200,000, indicating limited supply for lower-income households

Composition of Total Housing Units Launched by Price Range, Cumulative Percentage

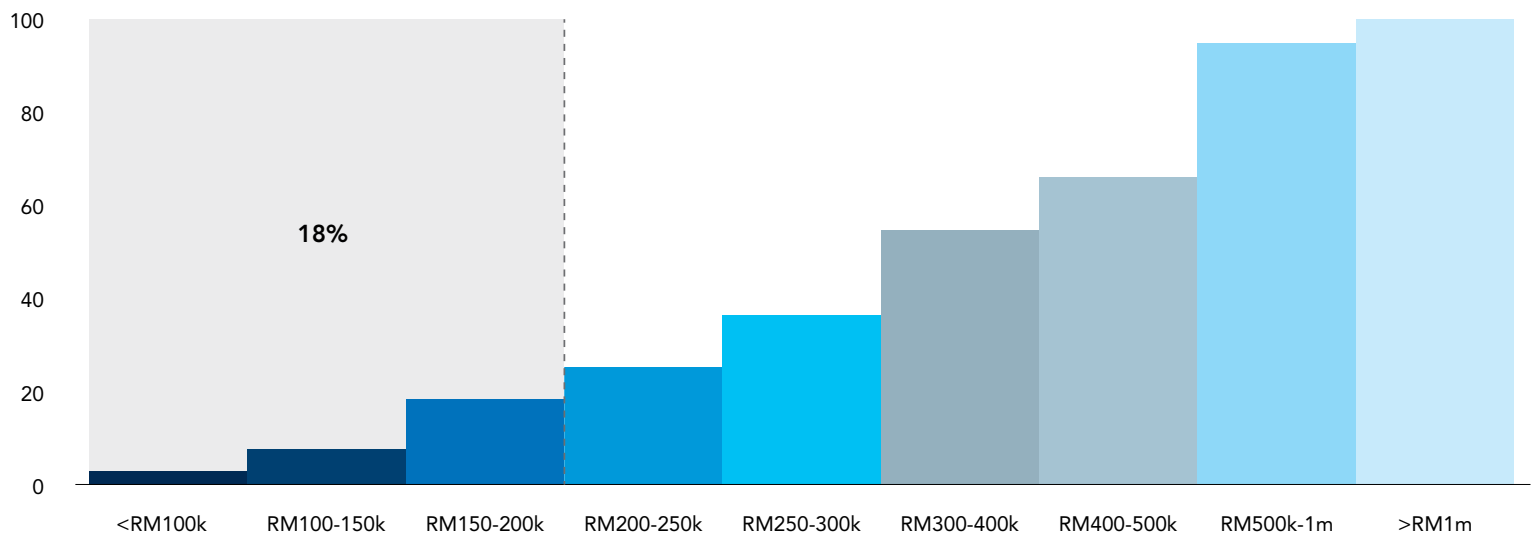




\section{Access to affordable housing varies significantly by location and household circumstances}

While the PIR is one of the most commonly used measures of housing affordability, it omits numerous household- and location-specific factors that determine affordability. Most notably, the PIR methodology does not account for the presence and quality of surrounding infrastructure and amenities, relevant costs associated with buying and owning a property, as well as the availability of housing supply relative to demand. As such, alternative approaches have been developed to address some of weaknesses of the PIR methodology (see Box 10 on alternative methods for assessing housing affordability). In addition, assessments of housing affordability should also take into account household-specific factors. Most prominently, lower-income households can typically only afford to devote a smaller share of their income to housing because other necessities, such as food, take up a larger share of the family budget than is the case for richer households (see Box 11).

To address some of the limitations of the PIR methodology, the World Bank developed a housing affordability model ${ }^{59}$ that measures households' capacity to pay for a mortgage across different income levels and compares that to the supply of housing at the affordable price points. The model is applied in two specific housing markets-Kuala Lumpur and Petaling District in Selangor state-to analyze housing affordability. Kuala Lumpur and Petaling District were chosen for comparative analysis because of their similarity in population size and income levels. This permits high-resolution analysis to highlight the areas of housing under-supply or over-supply at different price points and thus, the severity of housing unaffordability for different income levels. The affordability model uses a market-based approach. The starting point of this model is the determination of the capacity to pay, which is measured by the $\mathrm{DSR}^{60}$ traditionally used by lenders to determine the maximum mortgage amount for which a household would be eligible to borrow for the purchase of a home. The capacity-to-pay for a home loan (and the resulting affordable home price) is then assessed against the availability of housing supply at the relevant affordable price points in Kuala Lumpur and Petaling District, as tracked by Urbanmetry. ${ }^{61}$

\section{Lower-income households can only afford to devote a smaller share of their income to housing because other necessities, such as food, take up a larger share of the family budget.}

\begin{abstract}
Based on the housing affordability model, a household with monthly income of RM5,000 or more can afford a home valued up to approximately RM134,000, and a household with income of RM10,000 or more can afford a home valued up to RM500,000. The relatively conservative value of housing that may be considered as affordable for the lowest income households (RM5,000 and below) reflects the challenge this segment generally faces in accessing housing finance given their low and sometimes volatile income, the high cost of non-housing necessities relative to their income, and their small savings buffer (see Figure 71). Mortgage lenders generally are more comfortable in lending to households with incomes greater than RM5,000 as there is evidence that this segment is more likely to be able to adjust to adverse developments in their financial conditions. ${ }^{62}$
\end{abstract}

\footnotetext{
${ }^{59}$ As described in Table 9, the housing affordability measurements used in Australia, Canada and the USA are more precise by assessing the affordability of rental and owner-occupied housing costs using estimated payment capacity by specific geographic areas and income segments. Unfortunately, reliable data on the supply and cost of rental housing in Malaysia is extremely limited, and too limited to include rental housing in the World Bank affordability model developed for this analysis. See Appendix for details on the World Bank's affordability model.

60 The debt service ratio is the total amount debt repayment obligations (including principal, interest, fees) per month expressed as a percentage of monthly household income. Lenders can pull data on consumers' existing debt from the Credit Bureau Malaysia report, with the exception of debt obtained via informal lending channels or family networks.

${ }^{61}$ Urbanmetry is a big data housing research firm that combines public-sourced data with geo-location information through its proprietary algorithms, satellite imagery, and other tools that allow the measurement of housing affordability against the availability of supply-side data by pricing segments and by micro-market levels.

${ }^{62}$ BNM (2019), page 11
} 


\section{How is housing affordability assessed elsewhere?}

\begin{abstract}
Government agencies in many other countries use alternative measures of housing affordability that provide a more complete picture than the median multiple index. Canada's Mortgage and Housing Corporation uses a two-stage indicator to identify households in need of housing assistance. Their core housing need indicator determines need by assessing if a house is in adequate condition, suitable in size and if monthly housing-related costs are more than 30 percent of the household's pre-tax income. The Royal Bank of Canada's Housing Affordability Measure calculates affordability of housing for new buyers by assessing
\end{abstract}

the proportion of median pre-tax household income needed to pay for mortgage payments, property taxes, and utilities based on the prevailing market price of a home, with the costs differentiated by geographic area and type of dwelling. In Australia, the 30:40 standard identifies a housing burden when a household in the bottom 40 percent of the income distribution is paying more than 30 percent of its income on housing. The U.S. Department of Housing and Urban Development sets a benchmark for rental affordability as the ratio between the area Fair Market Rent (see below) to 30 percent of the median household income of a specific area.

\section{TABLE 9}

\section{Alternative housing affordability measurements/indicators}

\section{Housing Affordability Index Proponent of Index}

Core Housing Need
Canada Mortgage Housing Corporation

\section{Description}

Household is considered in core housing need from the affordability perspective if (i) rental plus utilities (for renters) or (ii) mortgage plus utilities, property taxes and condo fees (for owners) cost 30 percent or more of the household's pre-tax income. Estimate number of households in core housing need on an annual basis.

\section{Housing Affordability for Royal Bank of Canada} New Buyers Index

Estimates affordability for new buyers by calculating the proportion of median pre-tax household income needed to service the cost of mortgage payments, property taxes, and utilities based on the prevailing market price for single-family homes and condo apartments, disaggregated by cities or metropolitan areas, as well as for an overall aggregate of housing types in the market. Index is calculated on quarterly basis.

Identifies households as being in housing affordability stress when the household has an income level in the bottom 40 percent of Australia's income distribution and is paying more than 30 percent of its income in housing costs. The 30:40 standard recognizes that higher income households can exceed the 30 percent threshold without experiencing financial stress.

\section{Rental Affordability} Support
Australian Housing and Urban Research Institute
U.S. Department of Housing and Urban Development
Calculates the Fair Market Rent (FMR) as the 40th percentile of gross rents of recent movers in an area and the Area Median Income (AMI). The ratio of the FMR to 30 percent of the $\mathrm{AMI}$ is an overall indicator of housing affordability, and as a general principle rent subsidies are equal to the difference between the FMR and 30 percent of that household's monthly income (adjusted for household composition). 


\section{FIGURE 71}

Lower-income households face a relatively more conservative value of affordable housing

Maximum Affordable Home Value, RM

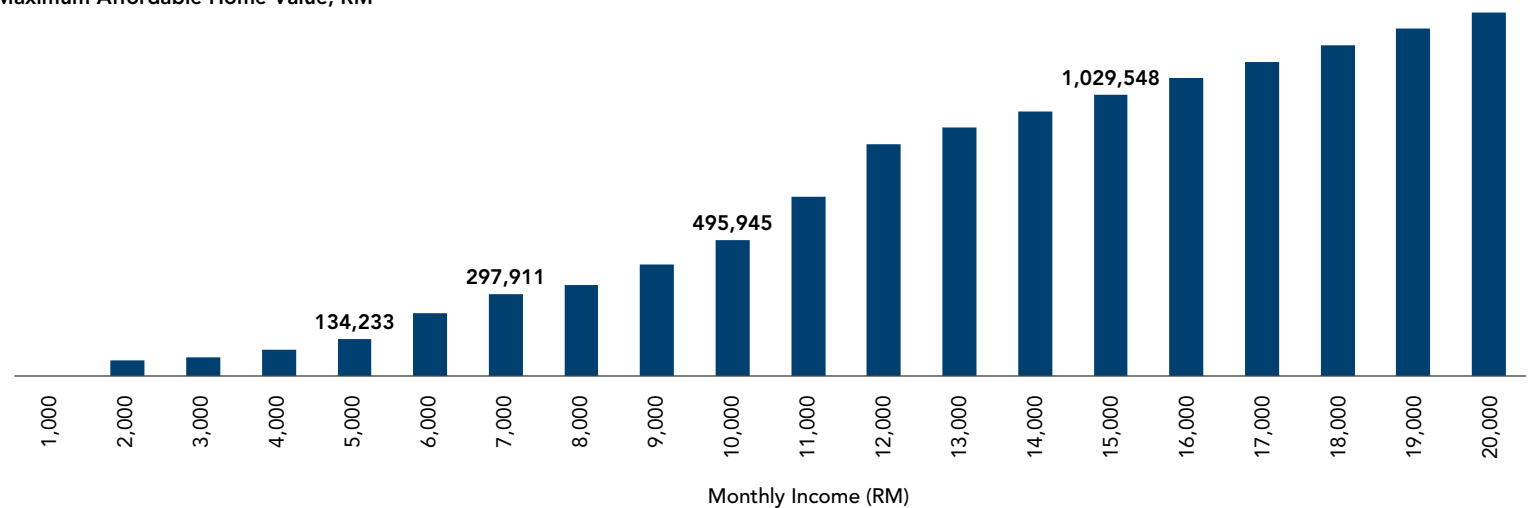

Source: BNM, World Bank staff calculations

The analysis conducted for Kuala Lumpur and Petaling District shows that households with monthly incomes less than RM5,000 experience severe housing unaffordability (see Figure 72 and Figure 73). Estimation using the World Bank affordability model indicates that these households can afford to buy a house costing up to RM134,000. The available housing supply at the price range of RM 134,000 and below is less than the number of households in the RM3,000-5,000 income bracket, such that an estimated 56 percent and 63 percent of households in this income segment in Kuala Lumpur and in Petaling District experience severe housing unaffordability, having no access to housing within their capacity-to-pay. Meanwhile, households with incomes from RM6,000

\section{FIGURE 72}

There is an under-supply of housing units that cater to lower-income households in Kuala Lumpur...

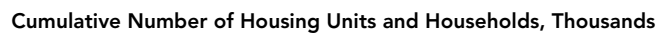

700

600

500

400

300

200

100

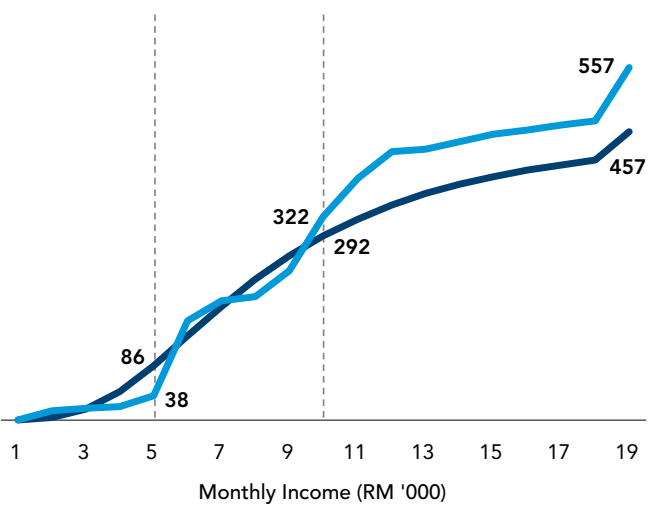

- Cumulative Number of Households

Cumulative Housing Units to RM10,000 have moderate difficulty purchasing an affordable home in line with their incomes. Households at this income level can afford to purchase homes in the range of RM230,000 to RM500,000 and the supply of homes in this price range relative to effective demand varies significantly between Petaling District and Kuala Lumpur. The supply and demand balance in this price range is also affected by competition from households earning more than RM10,000 per month who can afford homes costing RM500,000 or more but opt to purchase less expensive properties. Finally, housing affordability is not an issue for households with income of RM10,000 or more as there is an ample supply of homes within their capacity-to-pay.

\section{FIGURE 73}

...as well as in the Petaling District in Selangor

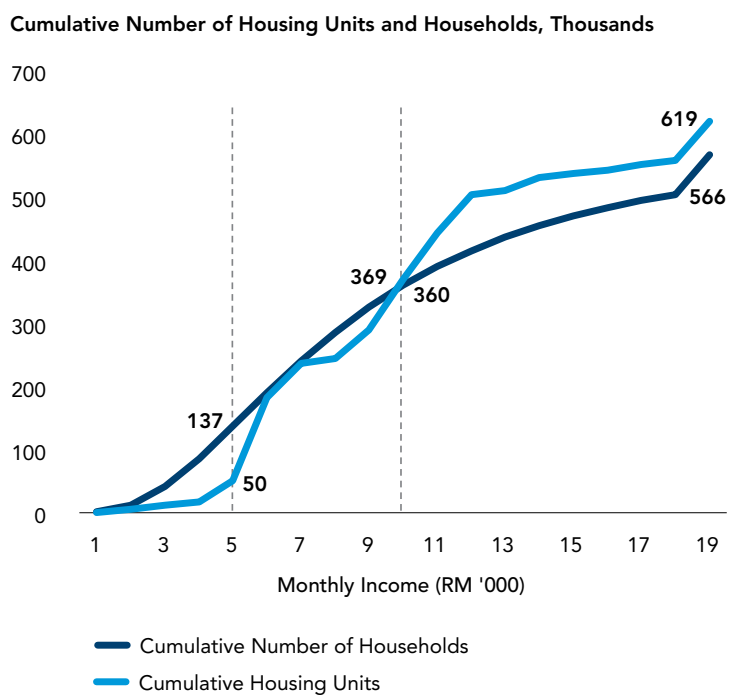

Source: Urbanmetry, World Bank staff calculations 


\section{Lack of affordable housing for B20, B21-B40 and M40 households}

Housing unaffordability was a common concern across all regions and ethnic groups in the joint World Bank-University of Malaya qualitative study. Participants from Klang Valley emphasized the price and quality of housing today as compared to the past, when their parents could afford decent-sized homes without feeling financially burdened. Over the years, home prices in both urban and rural areas have gone up beyond the financial capabilities of lower- and middle-income households, as illustrated below.

"My mother was a single parent. She was a civil servant, a teacher, and was able to afford to buy a house on her salary. A nice house. A big house. I mean, a good corner lot. Too big for us. But no, I cannot afford to buy such a house anymore. Even the house I am living in, she paid for it."

[Klang Valley, Chinese, M40]

"In Klang it is possible for us to buy a house? Is it possible to buy a house that costs 200,000? Will we get? [Klang Valley, Indian, M40]

"We barely have enough to eat, how can we buy a house?" [Terengganu, All participants, B20]

"Our money is not enough to buy a house. In the past, the houses were decent. Now they are smaller and more expensive. Our children don't live with us. If they did, we wouldn't fit!

[Klang Valley, Bumiputera, B21-B40]

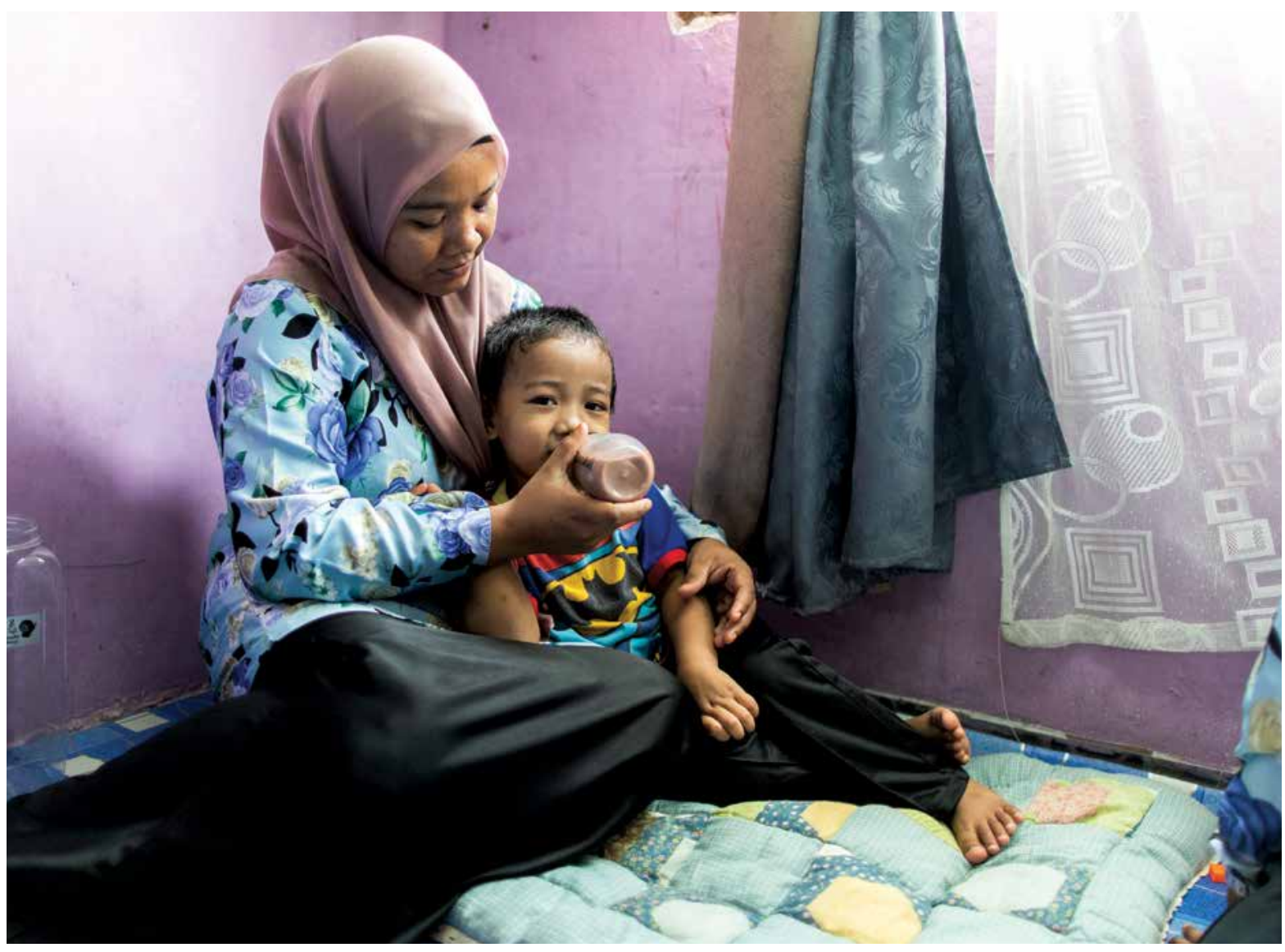




\section{Government housing policies have diverse impacts on housing supply and affordability}

National, state and local governments have been actively engaged in addressing the affordable housing needs of the people. In the National Housing Policy (2018-2025), the government has confirmed its commitment to ensuring sufficient safe and affordable housing for its population, and especially those in the B40 and M40. A review of the public housing schemes reveals that there is a total of 16 schemes $^{63}$ both on the supply and demand side. The following assessment of two of those government housing programs, Residensi Wilayah (formerly Rumah Mampu Milik Wilayah Persekutuan, RUMAWIP) and Rumah Selangorku, ${ }^{64}$ shows that one way that government policies affect housing affordability is in the manner that developers choose to build new housing at different price points, in part in response to these policies.

While the Residensi Wilayah scheme has contributed to the supply of housing units to the Kuala Lumpur market in the price range of RM300,000 and below, it also attracts higher-income households to take advantage of scheme. Higher-income households

\section{FIGURE 74}

Under the Rumah Selangorku scheme, developers overcompensate by building high-end units to subsidize for the construction of more affordable units

Supply of Housing Units, Thousands

20

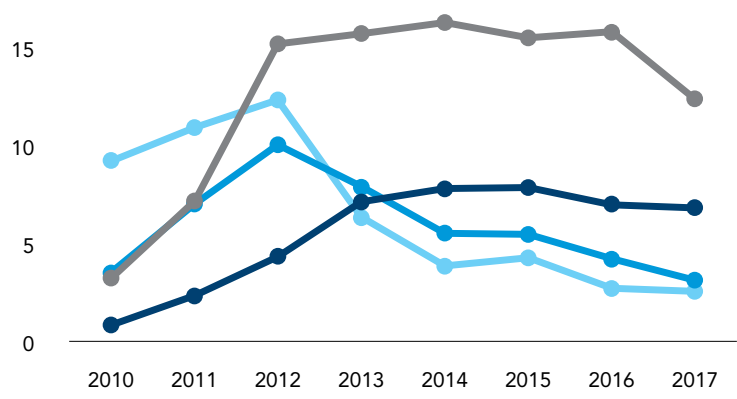

$\longrightarrow$ RM300k $\longrightarrow$ RM00k-RM500k

$\longrightarrow$ RM500k-RM1mil $\longrightarrow$ RM1mil with monthly income of RM15,000 can afford to purchase higher-priced homes of up to RM1 million but sometimes choose the Residensi Wilayah housing at RM300,000 due to its value-for-money and favorable characteristics such as central location and decent home size. Households with incomes from RM6,000 to RM10,000 whose ability to pay is in line with the Residensi Wilayah home prices are often crowded out by higher-income households with stronger capacityto-pay and better access to mortgage financing. Hence, the Residensi Wilayah housing scheme could be more effective in addressing affordable housing needs if the eligibility criteria were adjusted to cater to those with incomes of RM10,000 or less, and if the scheme placed tighter limits on the use of Residensi Wilayah for investment purposes instead of as the recipient's primary residence.

The Rumah Selangorku scheme exacerbates the under-supply situation in the Petaling District. Under this scheme, 20-50 percent of residential units in a new development are required to be priced

\section{FIGURE 75}

The Residensi Wilayah and Rumah Selangorku policies have partly contributed to the divergent residential market pricing trends

\section{Price Index}

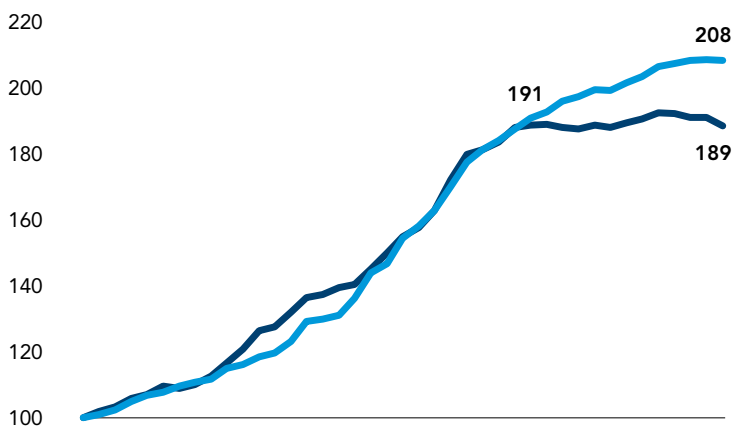

20082009201020112012201320142015201620172018

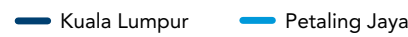

Source: Urbanmetry, World Bank staff calculations

${ }^{63}$ These include six schemes on the supply side (Projek Perumahan Rakyat (PPR), Perumahan Penjawat Awam Malaysia (PPAM), MyHome, Perumahan Rakyat 1 Malaysia (PR1MA), Rumah Selangorku, and Residensi Wilayah; five on the demand-side (BNM Fund for Affordable Homes, Skim Pinjaman Perumahan, My First Home Scheme, Youth Housing Scheme, and MyDeposit) to support home ownership; and five rental or rent-to-own schemes (PPR Disewa, Rent-to-own PPR, Program Rumah Transit, Skim Smart-Sewa Selangor, and Rent-to-own PR1MA).

${ }^{64}$ See Appendix for explanation on Residensi Wilayah and Rumah Selangorku. 
at less than RM250,000 while the remaining units may be priced at market levels. This has resulted in the increasing number of high-end units compared to lower-priced units in 2019, as developers overcompensate by building high-end units first to subsidize the subsequent construction of lowerend units in the Petaling market ${ }^{65}$ (see Figure 74). It is possible that developers will persist in building more high-end than affordable housing units or shift their developments elsewhere if they continue to feel constrained by the Rumah Selangorku policy. Hence, the scheme has created more homes in the higherincome segment in Petaling District.
The Residensi Wilayah and Rumah Selangorku policies have contributed to the residential housing market price trends. The housing over-supply in Kuala Lumpur is expected to worsen by 2023, with Residensi Wilayah contributing 17 percent of total incoming housing units. As a result, the housing over-supply (estimated total housing units compared to number of households) has already led to a stagnant and slightly declining home price trend for Kuala Lumpur as shown in Figure 75. On the other hand, the already-tight housing supply conditions in Petaling are likely exacerbated by the Rumah Selangorku policy, which has created more homes in the higher-income segment and resulted in continued increases in housing prices since 2014.

\section{Addressing Malaysia's cost of living challenge}

\begin{abstract}
This analysis identifies four main factors Malaysian households face in trying to make ends meet. These include consumer price inflation (especially differentials linked to income levels or geographic location), inadequate income, poor financial well-being, and a shortage of affordable housing. These factors overlap to some degree and are by no means exhaustive. Broadly, the findings show that the cost of living affects individual households differently, depending on various factors including demographics, location and employment. This also helps identify practical policy measures to address economic hardships related to perceptions of the increasing cost of living.
\end{abstract}

The cost of living varies widely by location, most notably for housing, but also for food, clothing, services and other necessities. It is not unusual for an item to cost almost twice as much in one state as in another. Higher living costs may be offset somewhat, but not completely, by higher incomes in that area. Recent initiatives such as BNM's living wage estimation and the Belanjawanku efforts by SWRC and EPF represent valuable steps toward recognizing, measuring and monitoring the magnitude of spatial differentials in prices. This could be supported by taking advantage of the price data that are already collected for the CPI to develop an official spatial price index and using it to inform public and private decisions, as is done in other countries. In contrast, with the notable exception of housing costs, consumer price inflation (the increase of prices over time) has not been a major contributor to rising living costs. Although low-income households are affected more by higher-than-average food price inflation, the impact of inflation is small relative to other factors such as spatial differences, lagging income growth, subpar financial well-being and rising housing costs.

\begin{abstract}
A large proportion of Malaysians feel that their income is insufficient, and the data suggest that this is particularly relevant for lower-income households and younger workers who have experienced slower income growth in recent years. Findings from the GWP show that both urban and rural Malaysian households feel growing hardship in their life conditions. Data from the DOSM's household income surveys suggest that lower-income households have experienced rapid growth in income between 2009 to 2014. However, income growth for this segment has slowed considerably and the absolute income gaps have widened, which could contribute to perceptions of being "left behind." Meanwhile, despite steadily increasing educational attainment, income growth among recent entrants to the labor force has grown only marginally over the past decade, especially relative to older age cohorts. Higher income growth rates and higher "base" incomes for older workers combine to amplify both relative and absolute income gaps between younger and older Malaysians, which could be another tangible measure of comparative well-being. Qualitative research points to significant increases in the number of people working multiple jobs and the number of household members who work. The available survey data indicates only modest increases, which may
\end{abstract}


be an artefact of the survey methodology and warrants further investigation and perhaps additional data collection.

Certain segments of the population are doing worse than others in terms of financial wellbeing, either because of high indebtedness, lack of financial knowledge, or poor financial and retirement planning. For lower-income households, borrowing provides temporary relief to compensate for income shortages in the near-term. Increasing shares of debt for credit cards, personal financing, and motor vehicle loans indicates the growing use of debt for consumption rather than for wealth accumulation over time. Consequently, lower-income households, as well as civil servants, have committed higher shares of their incomes to debt servicing, further reducing their income available to meet other living costs. In addition, most Malaysian households, particularly lower-income households, do not have adequate financial savings to cushion economic shocks or provide for their retirement. The lack of financial knowledge and literacy is widespread regardless of income and age, and contributes to the deterioration of financial well-being among Malaysians.
The conclusion that housing in Malaysia is seriously unaffordable might be an oversimplification of the reality of the market as low- to middleincome households face a higher degree of housing unaffordability. The housing affordability model developed for this analysis has found that housing affordability is not linear but changes as households have less or more income. Insufficient access to affordable housing is particularly severe among households earning below RM5,000 in Kuala Lumpur and in Petaling District, with an estimated 55 and 63 percent of households, respectively, without access to housing within their capacity-to-pay. Households in the RM6,000 to RM10,000 income bracket can typically afford to purchase a home in the RM230,000 to RM500,000 price range, but availability of such homes is very uneven. The market for such homes that are affordable for this income group is much tighter in Petaling District than in Kuala Lumpur, given Petaling's growing under-supply and increase in prices. The analysis also shows that housing affordability is not an issue for households with incomes greater than RM10,000 as they have ample choice of homes within their capacity-to-pay.

\section{Alleviating cost of living pressures demands a mix of short-term measures as well as medium- and long-term structural reforms}

\begin{abstract}
Recognizing the widespread concern about the cost of living and its impact on Malaysians' well-being, the government has taken several policy measures to improve Malaysians' living standards. Previously, many of the measures designed to address the cost of living were relatively ad hoc, fragmented and short-term in nature. Policies implemented by the government have included subsidies, administrative price controls, construction of affordable housing, concessional mortgage financing, and credit counseling. To have a more holistic and organized approach to mitigate cost of living pressures, the government has established the National Cost of Living Action Council (NACCOL), with the objective of identifying and analyzing a wideranging of issues and challenges relevant to addressing the cost of living, coming up with policy decisions, and coordinating implementation strategies across relevant ministries and agencies. NACCOL is chaired by the Deputy Prime Minister and the council's secretariat is the Ministry of Domestic Trade and Consumer
\end{abstract}

Affairs (KPDNHEP). Various government ministries and agencies are engaged in addressing cost of living concerns, including the Ministry of Economic Affairs, MOF, KPDNHEP, BNM, DOSM and others.

NACCOL has played an important role in addressing various cost of living issues through initiatives in food, housing, and transportation sectors. On food, the Festive Season Price Control Scheme (Skim Kawalan Harga Musim Perayaan) has been improved with a longer enforcement period and additional controlled items during festivities. The Food Bank Malaysia and Food Bank Siswa programs were also established to provide direct food resources to low-income households and university students in need. On housing, NACCOL has worked with BNM to introduce the Fund for Affordable Homes worth RM1 billion to provide loans for lower-income households to purchase housing priced at RM300,000 and below, at a maximum loan term of 40 years and financing rate 
of 3.5 percent. Other initiatives for affordable housing include the introduction of Rent-to-Own and Rental and Saving programs by the Ministry of Housing and Local Government. On transportation, the Ministry of Transport has implemented the RM50 and RM100 unlimited travel pass for RapidKL users, as well as 20 percent discount for rail users to encourage public transport use and reduce the costs of transportation among Malaysians.

As factors affecting households' living standards are wide-ranging and tend to overlap to some degree, a more structured approach to address the cost of living and improve well-being among Malaysians can be organized into short-term measures and medium- to long-term policies.
The broad guiding principle for short-term measures should be actions that can be implemented fairly quickly within 1-2 years. The objectives for short-term measures should be two-fold: first to provide solutions to alleviate hardships among lower-income households and increase awareness on these measures and second, to improve the current set of data and information that would help inform policy decisions. Meanwhile, medium- to long-term policies are those that tend to require strengthening coordination between ministries and agencies, for which the outcomes are observed over a longer period of time. These should aim to address structural reforms and to increase real incomes of low- and middle-income households (see Table 10 for a summary of policy recommendations).

\section{Short-term measures need to focus on alleviating hardships among lower-income households}

\begin{abstract}
Continuation of the ongoing reevaluation of price controls for selected commodities is advisable, with a view to identifying and resolving the underlying causes of undue price increases. Administrative price controls and other measures that limit price increases are relatively blunt instruments that may provide immediate relief but are difficult to sustain in the long run and run the risk of creating bigger and deeper challenges. If mechanisms to limit price discovery become entrenched, producers and traders may withdraw from the market if they cannot make a profit, while enforcement costs for curbing the growth of black markets are likely to increase. The analysis in this MEM has shown that overall price inflation is not currently a major contributor to the high cost of living in Malaysia.
\end{abstract}

For those commodities where sharp price increases are an issue, a focus on enhamcing market competition is appropriate, as in the recent examination of supply chains for certain fresh food items by the Malaysia Competition Commission (MyCC). If barriers prevent potential competitors from entering the market, producers or middlemen have low incentives to compete on prices and this ultimately affects consumers. To this end, tackling anticompetitive practices in key sectors is critical. However, this should be accompanied by measures to lift regulatory barriers in order to foster competition, especially in production and distribution. Similarly, measures to uncover and punish abuse of market dominance and anti-competitive practices such as illegal price fixing would also help.

In addition, the reevaluation of price controls should be aligned with the $\mathrm{B} 40$ consumption patterns to further reduce the cost of living pressures through price controls on frequently purchased items. The creation and timely reporting of an official spatial price index (SPI) would help address the current information gap about the large geographic differences in the cost of living. An SPI that tracks the cost of a given reference basket at different locations in the country will be useful for government policy making as well as for private employers. This would be in addition to a cost of living index that allows the basket composition to vary.

Easing the income shortfalls among low- and middle-income households in the near-term could entail deepening the existing social safety nets and extending the living wage analysis. Stylized simulations by the World Bank ${ }^{66}$ suggest that while the design of Bantuan Sara Hidup channels most of the benefits to the households with the lowest incomes, the depth of the program is quite limited (see Figure 76), resulting in only very modest reductions in income 


\section{FIGURE 76}

Malaysia's social safety net system remains relatively underdeveloped in terms of depth

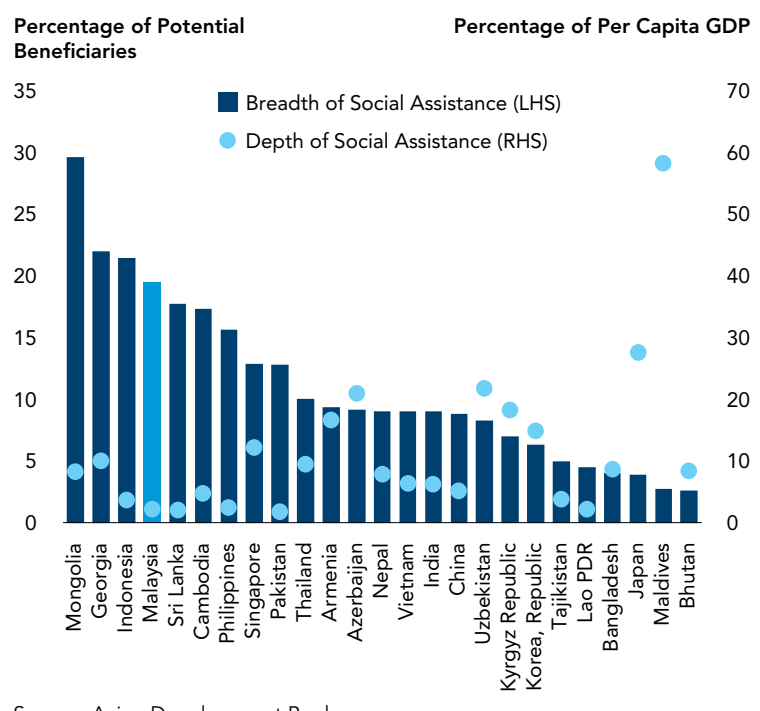

Source: Asian Development Bank

poverty and inequality. While BSH's impact could be improved foremost by increasing the total outlay and benefits, incorporating household size and location into BSH's eligibility criteria, in addition to benefit formulas, would also enhance its impact. Figure 77 illustrates a stylized simulation of BSH's performance using the Household Income and Expenditure Survey data, with 76.6 percent of the program benefits estimated to be received by B40 households, 20.8 percent by $\mathrm{M} 40$ and less than 3.0 percent by T20.

Short-term measures to strengthen the social safety net could also encompass a replacement of fuel subsidies by a transportation allowance that is income-targeted but independent of car or motorcycle ownership. This could be complemented by a strengthening of core social welfare programs implemented by the Department of Social Welfare, perhaps by reallocating resources from programs whose benefits are regressively distributed. Recent work by BNM on living wages and EPF/SWRC on reference budgets should continue to be extended to other regions in Malaysia and utilized as a wage bargaining framework according to specific household characteristics and locations.

Raising awareness among citizens on their rights and responsibilities in personal and household

\section{FIGURE 77}

Simulations suggest the Bantuan Sara Hidup could achieve a wider coverage and be more progressive

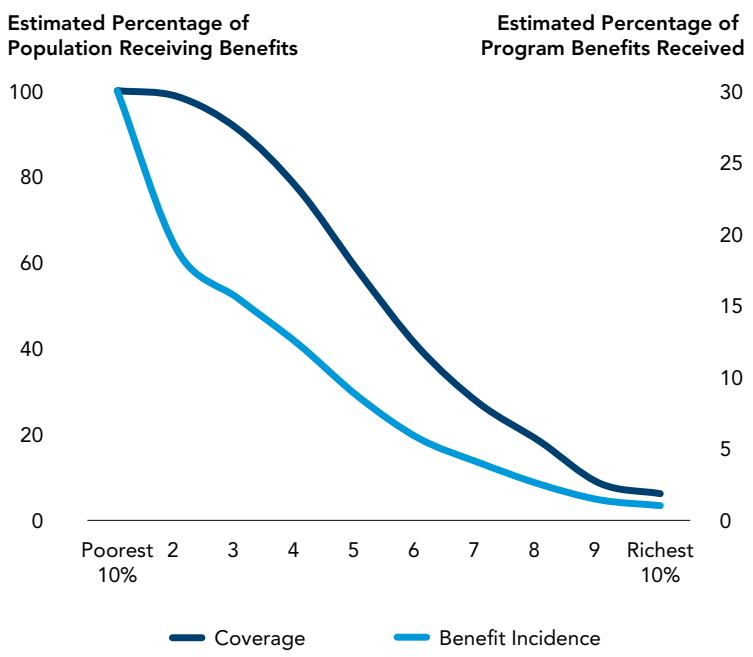

Source: World Bank staff calculations based on DOSM data

financial management and to be accountable for their financial decisions is an important first step towards improving financial well-being. Generating awareness of financial planning and the role of AKPK, providing easier access to resources and tools could help for financial planning, and coming up with a standardized measure to gauge financial literacy could help to improve financial knowledge especially among lower-income households, civil servants, and young adults. AKPK's role as the national credit counseling agency providing financial advisory services throughout different milestones in life, including guidance on student loans, could be more actively disseminated to the public.67 Official government channels and social media are effective tools for outreach and communication to all Malaysians on good financial practices and behavior. Continuing and strengthening current public and private financial literacy initiatives, for example those listed in Appendix 4, is important especially in reaching vulnerable groups such as single mothers, people with disabilities, youth and migrant workers.

Creating a repository of financial planning tools which are available online and in local languages could help lower-income households, civil servants and young adults make the first step in better planning their financial well-being. ${ }^{68}$ Concurrently,

${ }^{67}$ A survey conducted by the Malaysia Financial Planning Corporation suggests that only 55.8 percent of the respondents are aware of the role of AKPK. "Financial Capability and Utilization of Financial Advisory Services in Malaysia" - Report on National Findings 2018 https://mfpc.org.my/wp-content/uploads/2018/04/ CMDFreport2018.pdf

${ }^{68}$ At the moment, there are several online tools and apps, including in AKPK's website, available in English and Bahasa Malaysia. 
assessment of financial literacy levels over time through regular implementation of standardized measure of financial literacy such as BNM's Financial Capability and Inclusion Demand Side Survey could help policy makers to identify target groups, prioritize initiatives, and gauge the effectiveness of existing financial literacy program. ${ }^{69} \mathrm{~A}$ World Bank meta-analysis of 126 impact evaluations of financial education initiatives notes that more successful interventions depend on having higher intensity financial literacy programs and offering financial education at teachable moments, such as when buying a car or a house (Kaiser and Menkhoff 2018). Bruhn et al. (2014) also highlight the importance of having a stable and durable system such as the repository, which could provide greater benefits to lower income households, civil servants and young adults in the long run. Their findings suggest that working adults often have little interest and experience difficulty in accessing financial literacy interventions and that the benefits of financial education courses are minimal for shorter interventions.

In the short-term, policies to address the housing affordability gap could be sharpened through better affordability measurement and evidencebased housing supply data and analytics. Adopting a more precise housing affordability measurement, as has been done in this study, is useful for identifying the population subgroups and locations that face the biggest housing affordability challenges. This could be further enhanced by harnessing supply-side data that include both existing and incoming housing stocks by price segments, population demographics, size and growth pattern, and mortgage market dynamics for a more accurate representation of housing affordability. Strengthening the residential rental market could offer a means to alleviate the issue in the short run as households build their balance sheets and increase their income. There should be increased support for private and public rental housing development, rent-to-own schemes, and other affordable formal housing options for at-risk populations in both urban and rural areas facing acute housing price pressures. As such, the enactment of the Rental Tenancy Act and the establishment of a Tribunal Act coupled with the development of a rental database and rental affordability indicators would facilitate current efforts to provide affordable housing for all.

\section{Over the long run, greater coordination across agencies and implementation of structural reforms could help lift real incomes}

In a competitive market economy, prices relay valuable information about scarcity, thus price policies should respect price signals. Guiding principles for deciding when to intervene when price spikes occur include the reason for the price spike (exogenous supply disruption, anti-competitive behavior, etc.), the expected duration of the price increase, and the impact on public well-being. Fostering competition in production and distribution in key sectors, not only for domestic producers but also with regard to the entry of imported goods, will require careful investigation and vigilance. Price interventions by the government should be kept to a minimum to ensure sustainable market supply in the long run. When introducing new price measures, interventions ought to be time-bound and range-limited to manage fiscal risks over time. Interventions to address increasing prices should consider income relief to the most affected parties, as opposed to broad subsidies or price ceilings that can be fiscally costly, distort markets and encourage overconsumption of the item in question. Therefore, progressive shifts to protect the incomes of low- and middle-income households will be more useful than persistent price interventions in the long run.

Over the long term, sustainable household income growth needs to be grounded in accelerating labor productivity, realigning investment and hiring incentives, and enhancing the overall social safety net framework. Wage or salary increases solely indexed to the cost of living or raising minimum wages without concomitant labor productivity increases are not likely to be sustainable and may instead spur further consumer price inflation. ${ }^{70}$ Thus, acceleration

${ }^{69}$ OECD has produced a Toolkit for Measuring Financial Literacy and Financial Inclusion, which could be adopted for monitoring financial literacy. https://www. oecd.org/financial/education/2018-INFE-FinLit-Measurement-Toolkit.pdf

70 It is worth noting that minimum wages are a relatively blunt and inefficient way to improve the welfare of low-income households. This is because not all minimum wage workers are in low-income households (and not all workers in low-income households make the minimum wage) and because minimum wages that are set too high can cause unemployment to increase. 
of productivity growth is needed to sustainably boost Malaysians' earnings potential in the future. The realignment of investment and hiring incentives towards economic upgrading and creation of highquality jobs could also increase incomes for lowerincome households and younger workers.

Sustainable household income growth requires developing and improving human capital, particularly those directly related to employment and income outcomes, through the expansion of early childhood education and promotion of lifelong learning and upskilling among adult workers. Consolidation and enhancement of the various social assistance and subsidy programs, such as those under the purview of the Department of Social Welfare, the Ministry of Domestic Trade and Consumer Affairs and the Ministry of Agriculture, toward streamlined design and implementation can be effective for improving the income distribution and protecting the most vulnerable in Malaysia.

Financial literacy and well-being could be raised through clear implementation and regular monitoring and evaluation of the National Strategy for Financial Literacy 2019-2023 (NSFL), as well as increased financial incentives for savings behavior. Recognizing the large room for improvement in financial literacy among Malaysians, the government has launched the NSFL with the aim of elevating the financial well-being across income group, age group, gender, and region. It sets out five priority areas encompassing all stages of the life-cycle. One way of building upon the NSFL is to lay out a timebound roadmap on the implementation and regular monitoring and evaluation of measures in the strategy. To address low savings among Malaysians, evidencebased behavioral interventions and financial incentives such as matching pension contributions could encourage higher retirement savings among lowerincome households, civil servants, and young adults.

Efforts to increase financial well-being would also need to be complemented by measures to strengthen consumer protection and encourage more responsible behavior by both banks and non-bank financial institutions. This would include strengthening of the legal and regulatory framework for consumer protection and responsible lending, as well as ensuring an efficient and humane insolvency system and non-judicial alternatives. Recent announcements by BNM to improve the Consumer Credit Act, including elements such as (i) promoting prudent and responsible lending practices among credit providers; (ii) safeguarding the wellbeing of consumers; (iii) supporting more coordinated and consistent oversight arrangements for credit providers; and (iv) facilitating transparent and comparable disclosure of interest rates and fees are all promising mechanisms to strengthen consumer protection. Consumers' associations have offered detailed recommendations for the new act that could be relevant to the prevention of overindebtedness, including taking a broader view of consumer credit to address actors outside their current regulatory perimeter, such as pawnbrokers, who are currently licensed under the Housing Ministry, regulating marketing practices (truth in advertising), cooling off periods for all types of loans, encouraging early loan repayment and prohibiting calculation of interest rates on a flat basis.

\section{Current housing policies should prioritize low-} and middle-income households and strengthen coordination among various stakeholders to ensure adequate supply of affordable housing. The National Housing Policy should be finetuned to provide support for households in the low- and middle-income groups, through increased focus on research, policy, budget and operational support to address severe unaffordability. This can be complemented by ongoing monitoring and analysis of the impact of different policies on the constantly shifting real estate market so that policy makers can adjust housing policies and programs as necessary. Policies could improve the planning of affordable housing community design with energy-efficient building materials and familyfriendly locations. Housing is an important component of the urban center, and is intimately intertwined with transportation networks, social infrastructure such as health and education facilities, community services, employment centers and access to markets and information. As such, integrating housing development as part of urban and regional planning should help ensure the balance of supply and demand of affordable housing-either for ownership or rental-to the targeted population. Thus, there is a need for greater coordination across ministries, agencies as well as state and local governments in designing overall housing policy and planning to ensure an adequate supply of affordable housing, particularly for the low- and middle-income households. 


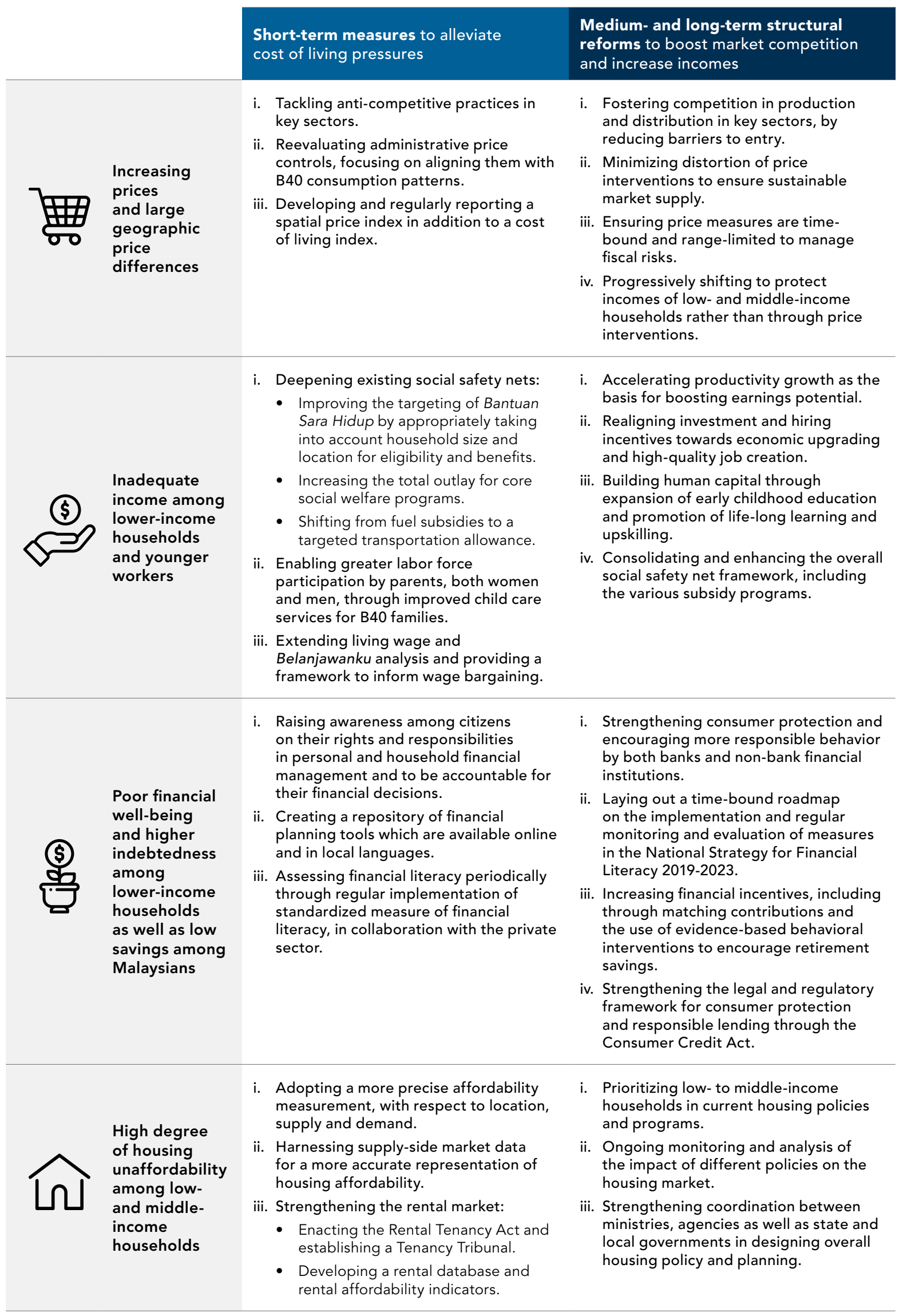





\section{Appendices}

\section{Appendix 1: World Bank housing affordability analysis}

Calculations for World Bank housing capacity-to-pay:

- Housing Capacity-to-Pay or the Monthly Housing Loan Repayment Obligation is calculated as: (Net $\mathrm{HH}$ income $\times$ DSR) - Other Debt Obligations.

- Net Household Income: Gross HH income less all required deductions for Employees Provident Fund (EPF), Social Security Organization (SOSCO), Employment Insurance System (EIS) and Income Tax as per the prevalent regulations and guidelines laid out for the different deductions.

- Level of Debt Service Ratio: The level of DSR applied by the World Bank is aligned with the international DSR benchmarks and is scaled from a conservative level of DSR on Net Household Income for lower-income segments starting at 30 percent to a more liberal level of DSR at a max of 60 percent for higher-income segments. This translates to a DSR range of 27 percent to 43 percent based on Gross $\mathrm{HH}$ income. This is also comparable with the BNM weighted average DSR ${ }^{71}$ of 34 to 40 percent for all Malaysian consumers across all income segments.

- Other Debt Obligations: Other Debt Obligations are comprised of personal loan, credit card loan, motor vehicle loan, securities loan and others. To calculate Other Debt Obligations, BNM's composition of household debt by purpose and income group ${ }^{72}$ was used. For instance, for a household with income segment of monthly income of RM 3,000, Other Debt Obligations account 65 percent of Total Debt Obligations, thus resulting in Housing Loan Repayment Obligations accounting for 35 percent of the Total Debt Obligations.

\section{Appendix 2: Residensi Wilayah}

Residensi Wilayah, formerly known as RUMAWIP or Rumah Mampu Milik Wilayah Persekutuan, is a government affordable housing scheme that caters to the people working or living in the three federal territories of Putrajaya, Kuala Lumpur and Labuan. Under the Residensi Wilayah program, developers are allowed a Floor Area Ratio (FAR) above the standard regulated densification level as an incentive to build affordable housing. By being allowed to build at a higher density, developers can offset the loss of selling units at a lower price point. The scheme aims to build a total of 80,000 units of affordable homes by the year 2020, of which 50,000 units are to be developed in $K L, 20,000$ units in Putrajaya and 10,000 units in Labuan. Residensi Wilayah units are priced at less than RM300,000 and are only available for first-time home buyers with income below RM10,000 per month for single individuals or RM15,000 per month for married couples. In addition, the Residensi Wilayah properties are restricted from being sold during the first ten years but can be rented out to others. 


\section{Appendix 3: Rumah Selangorku}

The Selangor State Government launched the Rumah Selangorku scheme in 2014 with the aim of increasing the supply of housing priced at less than RM250,000. Under this inclusionary housing policy, 20 to 50 percent of residential units in a new development are required to be priced at less than RM250,000 while the remaining units may be priced at market levels. See Table 11 for more details. Rumah Selangorku is only available for first-time home buyers, whereby households with monthly income less than RM3,000 are eligible for Type A homes with prices of RM42,000 and households with income between RM3,000 and RM10,000 are eligible for Types B, C, and D homes with prices of RM250,000 or less. Buyers must be primary residents for at least five years before a resale can take place.

TABLE 11

Requirements for developers to build affordable housing units under the Rumah Selangorku scheme

\begin{tabular}{lccccc} 
Development zone & \multicolumn{5}{c}{ Provision for Rumah Selangorku based on total development area (Percentage) } \\
\hline Zone 1 & $2-5$ acres & $5-10$ acres & $10-20$ acres & $20-50$ acres & $>50$ acres \\
\hline Zone 2 & $20 \%$ & $30 \%$ & $40 \%$ & $50 \%$ & $50 \%$ \\
\hline Zone 3 & - & $20 \%$ & $40 \%$ & $40 \%$ & $50 \%$ \\
\hline
\end{tabular}

\section{Appendix 4: Summary of financial literacy initiatives in Malaysia}

\begin{tabular}{|c|c|c|}
\hline Organization & Year & Programs/Services/Tools \\
\hline $\begin{array}{l}\text { Agensi Kaunseling dan } \\
\text { Pengurusan Kredit }\end{array}$ & 2006 & $\begin{array}{l}\text { Financial Counseling } \\
\text { - Offers one-to-one counseling and advice on good financial } \\
\text { management habits, including budgeting, money management, and } \\
\text { credit-related matters } \\
\text { Debt Management Programme (DMP) } \\
\text { - Offers consultation and personalized debt repayment plan for } \\
\text { individuals experiencing financial distress }\end{array}$ \\
\hline $\begin{array}{l}\text { Malaysian Financial } \\
\text { Planning Council }\end{array}$ & 2008 & $\begin{array}{l}\text { "My Money and Me" Financial Management Workshop } \\
\text { - Target groups: youths, civil servants, lower-income households, } \\
\text { - Workergraduates, and employees (special workshops) } \\
\text { per session (full-day workshop) } \\
\text { - In collaboration with Perbadanan Insurans Deposit Malaysia (PIDM), } \\
\text { Federation of Investment Managers Malaysia (FIMM), Lembaga } \\
\text { Hasil Dalam Negeri (LHDN), Social Security Organization (SOCSO/ } \\
\text { PERKESO), Securities Commission Malaysia (SC), Agensi Kaunseling } \\
\text { dan Pengurusan Kredit (AKPK), Permodalan Nasional Berhad (PNB), and } \\
\text { Employees Provident Fund (EPF) }\end{array}$ \\
\hline
\end{tabular}




\section{Organization Year Programs/Services/Tools}

Financial Literacy Programme

Malaysian Care

2010

- Aims to reduce poverty through capacity building and equipping poor people with basic financial knowledge - over 800 participants in Klang Valley have undergone training; 100 have started small businesses/ projects

"My Finance Coach"

- A financial literacy program aimed at improving financial literacy Allianz Malaysia

2012 among students and young people through promotion of good money management habits

- Reaching 102 schools and organizations with over 10,000 students in 2017

The Edge Education

Foundation (in collaboration with Citi Foundation)

"Money \& Me: Youth Financial Empowerment Programme"

- School-based program, emphasis on saving and good spending habits

- 13 participating schools in Klang Valley

"Cha-Ching Live", "Karnival Cha-Ching", "Duit Right"

Prudential Assurance Malaysia (Prudential Corporation Asia and

Prudence Foundation)

- For 7-15 year-olds

- Interactive financial education program for 7-15 year-olds, available offline and online (learning activities, TV episodes, and games)

- Main focus: "Earn, Save, Spend, and Donate"

"InvestSmart"

Securities Commission Malaysia

- Focuses on investment education; offers various programs ranging from InvestSmart Fest, SC-in-the-Community, seminars, mobile application, and "Jump2Invest" educational game
Financial Literacy for Youths
Online Publications

- Provide the latest information on personal finance, economics, and fintech industry for youths.

"Karnival Kewangan"

- The Financial Carnival has been held in Kuala Lumpur, Kedah, Terengganu, Sabah, and Sarawak, and it offers financial services

Bank Negara Malaysia and advice, financing briefing, as well as entertainment activities for families - children, youths, adults - to learn about effective financial management

"Belanjawanku: Malaysian Individual and Family Expenditure Guide"

- An expenditure guide that suggests the minimum monthly budget for different households in Klang Valley

Employees Provident Fund

Retirement Advisory Service (RAS) Professional Consultation

- Provide EPF members with knowledge on sustainable retirement options, as well as conduct awareness programs on retirement planning

Agensi Kaunseling dan Pengurusan Kredit

- Free online courses such as the "Rumahku" module that guides firsttime home buyers (in English and Malay Languages)

Bank Negara Malaysia Agensi Kaunseling dan Pengurusan Kredit, and Credit Guarantee Corp Malaysia

Financial Education Network (FEN)
Financing Advisory Services (MyKNP - Khidmat Nasihat Pembiayaan)

- Offers advice to home buyers and small and medium enterprises (SMEs) that cannot secure financing, while assessing ways to improve their eligibility for future financing
National Strategy for Financial Literacy 2019-2023

- Five-year roadmap to intensify financial education initiatives through collaborative and coordinated efforts among public-private agencies and others 


\section{References}

AKPK (2014) 'More Malaysians are spending well beyond their means', Kuala Lumpur: Agensi Kaunseling dan Pengurusan Kredit.

AKPK (2018) Financial Behaviour and State of Financial Well-Being of Malaysian Working Adults, Kuala Lumpur: Agensi Kaunseling dan Pengurusan Kredit.

AIF (2015) Finance Matters: Understanding Gen Y, Kuala Lumpur: Asian Institute of Finance.

BNM (2016) Looking Beyond Headline Household Debt Statistics, Financial Stability and Payment Systems Report 2016, Kuala Lumpur: Bank Negara Malaysia.

BNM (2017) Indebted to Debt: An Assessment of Debt Levels and Financial Buffers of Households, Financial Stability and Payment Systems Report 2017, Kuala Lumpur: Bank Negara Malaysia.

BNM (2017b) Affordable Housing: Challenges and the Way Forward, Quarterly Bulletin, Fourth Quarter 2017, Kuala Lumpur: Bank Negara Malaysia.

BNM (2018a) The Living Wage: Beyond Making Ends Meet, Kuala Lumpur: Bank Negara Malaysia.

BNM (2018b) Risk Developments and Assessment of Financial Stability in 2018, Financial Stability and Payment Systems Report 2018, Kuala Lumpur: Bank Negara Malaysia.

BNM (2018c) Market Conduct and Consumer Empowerment, Financial Stability and Payment Systems Report 2018, Kuala Lumpur: Bank Negara Malaysia.

BNM (2018d) Civil Servants' Debt: Risks and Policy Considerations, Financial Stability Review - First Half 2018, Kuala Lumpur: Bank Negara Malaysia.

BNM (2019a) Annual Report, Kuala Lumpur: Bank Negara Malaysia.

BNM (2019b) Quarterly Bulletin, Kuala Lumpur: Bank Negara Malaysia.

BNM (2019c) Financial Stability Review - First Half 2019, Kuala Lumpur: Bank Negara Malaysia.

Bruhn, Miriam, Gabriel Lara Ibarra and David McKenzie (2014) "The Minimal Impact of a Large-Scale Financial Education Program in Mexico City", Journal of Development Economics 108:184-189.

Cuberes, David and Marc Teignier (2019) 'The Aggregate Gains of Eliminating Gender and Ethnic Gaps in the Malaysian Labor Market', unpublished working paper, The World Bank.

CompareHero.my (2019) 'Credit Cards', https://www.comparehero.my/credit-card/all.

Demographia (2019) "15th Annual Demographia International Housing Affordability Survey: 2019", Belleville, IL, USA: Demographia and The Public Purpose.

Dimock, Michael (2019) "Defining generations: Where Millennials end and Generation Z begins", Washington, DC: Pew Research Center. January 17.

DOSM (2009) Household Expenditure Survey, Putrajaya: Department of Statistics Malaysia.

DOSM (2014) Household Expenditure Survey, Putrajaya: Department of Statistics Malaysia.

DOSM (2015) Distribution \& Use of Income Accounts and Capital Account, Putrajaya: Department of Statistics Malaysia.

DOSM (2016) Household Expenditure Survey, Putrajaya: Department of Statistics Malaysia.

DOSM (2016) Household Income and Basic Amenities Survey, Putrajaya: Department of Statistics Malaysia.

DOSM (2019) Salaries and Wages Survey Report 2018, Putrajaya: Department of Statistics Malaysia.

EPF (2018) Social Protection Insight: A Better Tomorrow, Kuala Lumpur: Employees Provident Fund.

EPF (2019) Belanjawanku: Expenditure Guide for Malaysian Individuals and Families, Kuala Lumpur: Employees Provident Fund.

EPU/UNDP (2007) Malaysia: Measuring and Montioring Poverty and Equality, Kuala Lumpur: United Nations Development Programme. 
FEN (2019) Malaysia National Strategy for Financial Literacy 2019-2023, Malaysia: Financial Education Network.

Free Malaysia Today (2019) "Malaysian millennials save money but don't invest, survey finds." October 2.

Goodhart, Charles A.E. (1989) Money, Information and Uncertainty, Basingstoke: Macmillan.

IISD (2013) Guidebook to Fuel Subsidy Reform for Policy Makers in Southeast Asia, Global Subsidies initiative, Geneva: International Institute for Sustainable Development.

IFC (2017) Tackling Childcare - The Business Case for Employer-Supported Childcare, Washington, DC: International Finance Corporation.

IMF (2019a) Malaysia: Article IV Consultation, Staff Report, IMF Country Report No. 19/71, Washington, DC: International Monetary Fund.

IMF (2019b) 'Frontiers of Economic Policy Communications', Departmental Paper No. 19/08, Washington, DC: International Monetary Fund.

Ismail, Suraya et al. (2019) Rethinking Housing: between State, Market and Society: A Special Report for the Formulation of the National Housing Policy (2018 - 2025), Kuala Lumpur: Khazanah Research Institute.

Jomo, Kwame S. (2017) "Most Malaysians cannot afford to retire". The Star Online. October 25.

Kaiser, Tim and Lukas Menkhoff (2017) 'Does Financial Education Impact Financial Literacy and Financial Behavior, and If So, When?', World Bank Economic Review 31(3):611-630.

KRI (2016) The State of Households II, Kuala Lumpur: Khazanah Research Institute.

Khidhir, Sheith (2019) "Malaysia's millennials need help". The Asean Post. September 27.

Loayza, N. and S. Pennings (2018) The Long-Term Growth Model, http://www.worldbank.org/LTGM.

Malaysian Department of Insolvency (2018) Bankruptcy Statistics Disember 2018, Putrajaya: Malaysian Department of Insolvency.

Ministry of Finance (2019) Fiscal Outlook and Federal Government Revenue Estimates 2020. Ministry of Finance, Putrajaya: Government of Malaysia.

Okun, Arthur M. (1970) The Political Economy of Prosperity, Washington, DC: The Brookings Institution.

RinggitPlus (2019). "Are Malaysians In Denial of Their Financial Reality?" Kuala Lumpur: RinggitPlus.

Vase.ai (2019) 'Malaysia Millennial Savings Aspiration', Selangor: Vase.ai.

World Bank (2015) Achieving a System of Competitive Cities in Malaysia, Washington, DC: The World Bank.

World Bank (2018a) Global Economic Prospects: Broad-based Upturn, but for How Long? January, Washington, DC: The World Bank.

World Bank (2018b) Malaysia Economic Monitor, December 2018: Realizing Human Potential, Washington, DC: The World Bank.

World Bank (2019a) Malaysia Economic Monitor, June 2019: Re-energizing the Public Service, Washington, DC: The World Bank.

World Bank (2019b) Estimating the Number of Foreign Workers. Washington, DC: The World Bank.

World Bank (2019c) Breaking Barriers - Toward Better Economic Opportunities for Women in Malaysia, Washington, DC: The World Bank.

World Bank (2019d) Global Economic Prospects, June 2019: Subdued Investment, Washington, DC: The World Bank.

World Bank (2019e) East Asia and Pacific Economic Update, October 2019: Weathering Growing Risks, Washington, DC: The World Bank.

World Bank and University of Malaya (forthcoming) 'Qualitative Study on Living Standards in Malaysia', Washington, DC: The World Bank. 



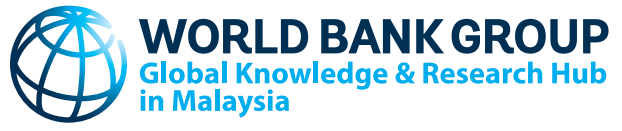

\title{
CONNECT WITH US
}

\author{
wbg.org/Malaysia
}

f@WorldBankMalaysia

@WB_AsiaPacific

http://bit.ly/WB_blogsMY 
